\title{
31. PYROXENE GEOTHERMOMETRY OF BASALTS AND AN ANDESITE FROM THE PALAU-KYUSHU AND WEST MARIANA RIDGES, DEEP SEA DRILLING PROJECT LEG 59
}

\author{
Teruaki Ishii, Ocean Research Institute, University of Tokyo, Minamidai, Nakano-ku, Tokyo 164, Japan
}

Appendix: "Data on Major-Element Compositions of DSP Leg 59 Tholeiitic Basalt, Calc-Alkalic Andesite, and Glass Obtained by Wet Chemical Analysis, XRF, and EPMA Methods," by Teruaki Ishii and Hiroshi Haramura

\begin{abstract}
Pyroxenes contained in island-arc type basalts and a calc-alkalic andesite from DSDP Leg 59, underwent microprobe analyses; from these data pyroxene geothermometry was calculated. The samples were plagioclase-augitebronzite- $( \pm$ )pigeonite phyric tholeiitic basalt lavas and intrusive units from Holes 448 and $448 \mathrm{~A}$ on the Palau-Kyushu remnant arc and plagioclase-augite-orthopyroxene-titanomagnetite phyric basalt clasts and a calc-alkalic andesite clast from Hole 451 on the West Mariana remnant arc.

The crystallization trend of pyroxene in magma chambers (delineated by tracing the cores of phenocrysts in the lavas) differs from that in the groundmass of lavas.

Magma temperatures, which can be represented by the crystallization temperatures of phenocryst pyroxenes, are estimated to be between $1130^{\circ}$ and $1075^{\circ} \mathrm{C}$ for the Site 448 basalts and about $1055^{\circ} \mathrm{C}$ for the Site 451 basalts. These basalts have solidification indexes between 34 and 19 . In contrast, a $970^{\circ} \mathrm{C}$ temperature is estimated for a Site 451 calc-alkalic andesite with a solidification index of 20.

Differences in volatile content, particularly water, appear to be the controlling factors in determining these temperatures. The water content of tholeiitic magmas is presumably lower than that of calc-alkalic magmas.
\end{abstract}

\section{INTRODUCTION}

Various hypotheses have been proposed regarding the origin of the ridge-basin system in the Philippine Sea (Karig, 1975; Uyeda and Ben-Avraham, 1972; Hilde et al., 1977). Karig (1975) suggests that a remnant arc-arc system of Palau-Kyushu-West Mariana-Mariana ridges was formed by opening of the Parece Vela Basin and Mariana Trough. However, very little petrological data have been available on these inactive remnant arcs.

During the DSDP Leg 59 cruise, orthopyroxenebearing rocks (lavas, intrusive rocks, and volcaniclastic breccias and tuffs) were obtained from Site 448 on the Palau-Kyushu Ridge and Site 451 on the West Mariana Ridge.

Pyroxenes of six representative two-pyroxene rocks from these ridges were analyzed by electron probe microanalyzer. On the basis of the resulting data, crystallization trends of groundmass pyroxenes in the lavas and phenocryst pyroxenes from the magma chamber were determined, and the temperatures of these magmas were estimated by pyroxene geothermometry (Ishii et al., 1976, 1979). The relations between estimated lava temperatures and the bulk composition of the calc-alkalic andesite will be reported. The origin of the magma will be discussed in comparison with previous results (Ishii, 1974; 1976; 1978). Data on majorelement compositions of other rocks analyzed from cores collected on DSDP Leg 59 are included in the Appendix.

\section{ANALYTIC METHOD}

Chemical compositions of rock-forming minerals were determined with a Japan Electron Optics Laboratory electron probe micro- analyzer (EPMA) Model JXA-5, which has a $40^{\circ}$ take-off angle. The analytic method is the same as that described by Nakamura and Kushiro (1970a).

Because most of the rock-forming minerals in volcanic rocks are in many cases zoned, their compositional range was determined by careful analysis. Initially, their compositional zoning was observed by scanning and partial analyses of three elements; then major elements were analyzed at several points. Glass was analyzed with a specimen current of $0.02 \mu \mathrm{amps}(\mathrm{A})$ and an electron beam size of 2 to $3 \mu \mathrm{m}$. To avoid light-element volatilization, the glass sample was moved rapidly over a wide area during analysis. Ten or more counts were averaged for each glass.

$\mathrm{X}$-ray fluorescence (XRF) analyses of the major elements of rocks were carried out with a Rigaku Memory Controlled Free Automatic Sequential Vacuum X-ray Spectrometer Geigerflex System No. 3064, with a current of $45 \mathrm{Kv}$ and $30 \mathrm{~mA}$. The analytic method is the same as that described by Matsumoto and Urabe (personal communication).

\section{DESCRIPTION OF ROCKS AND MICROPROBE ANALYSES}

DSDP Site 448 is located on the western edge of the Palau-Kyushu Ridge at a water depth of 3500 meters. Penetration was successful to a sub-bottom depth of 584.5 meters for Hole 448 and 914.0 meters for Hole 448A. Holes 448 and $448 \mathrm{~A}$ are treated as one sequence. The first igneous rock was cored at $\mathbf{3 3 7 . 5}$ meters subbottom. The underlying igneous complex consists of an alternation of basaltic lavas, intrusive rocks, and pyroclastic rocks. The 27 igneous rock units are classified into 6 petrographic groups, according to the assemblage of phenocryst minerals : (1) aphyric basalts (6 units), (2) plagioclase-phyric basalt (2 units), (3) plagioclase-olivine-phyric basalt ( 2 units), (4) plagioclase-augite-phyric basalt (10 units), (5) plagioclase-olivine-augite-phyric basalt ( 3 units), and (6) plagioclase-augite-orthopyroxene phyric basalt (4 units). Group 6, which will be called two-pyroxene rocks, occurs as pillow lavas or flows and as a dike at sub-bottom depths of 521 to 575 meters and 
887 to 897 meters, respectively. Three rocks selected from Group 6 were used for detailed petrologic studies.

Site 451 is located on the eastern side of the West Mariana Ridge at a water depth of 2060 meters. The site was cored continuously to a sub-bottom depth of 930.5 meters. A thick sequence of massive volcaniclastic breccias and tuffs were recovered between 65.5 and 930.5 meters. Within the volcaniclastic breccias, four petrographic groups of volcanic clasts are recognized: (1) aphyric or sparsely phyric basalt, (2) plagioclase-augitephyric basalt, (3) plagioclase-augite-titanomagnetitephyric basalt and (4) plagioclase-augite-orthopyroxenetitanomagnetite-phyric basalt and andesite. Groups 3 and 4 contain the most abundant clasts. Three rock samples from Group 4 were selected for detailed petrologic studies.
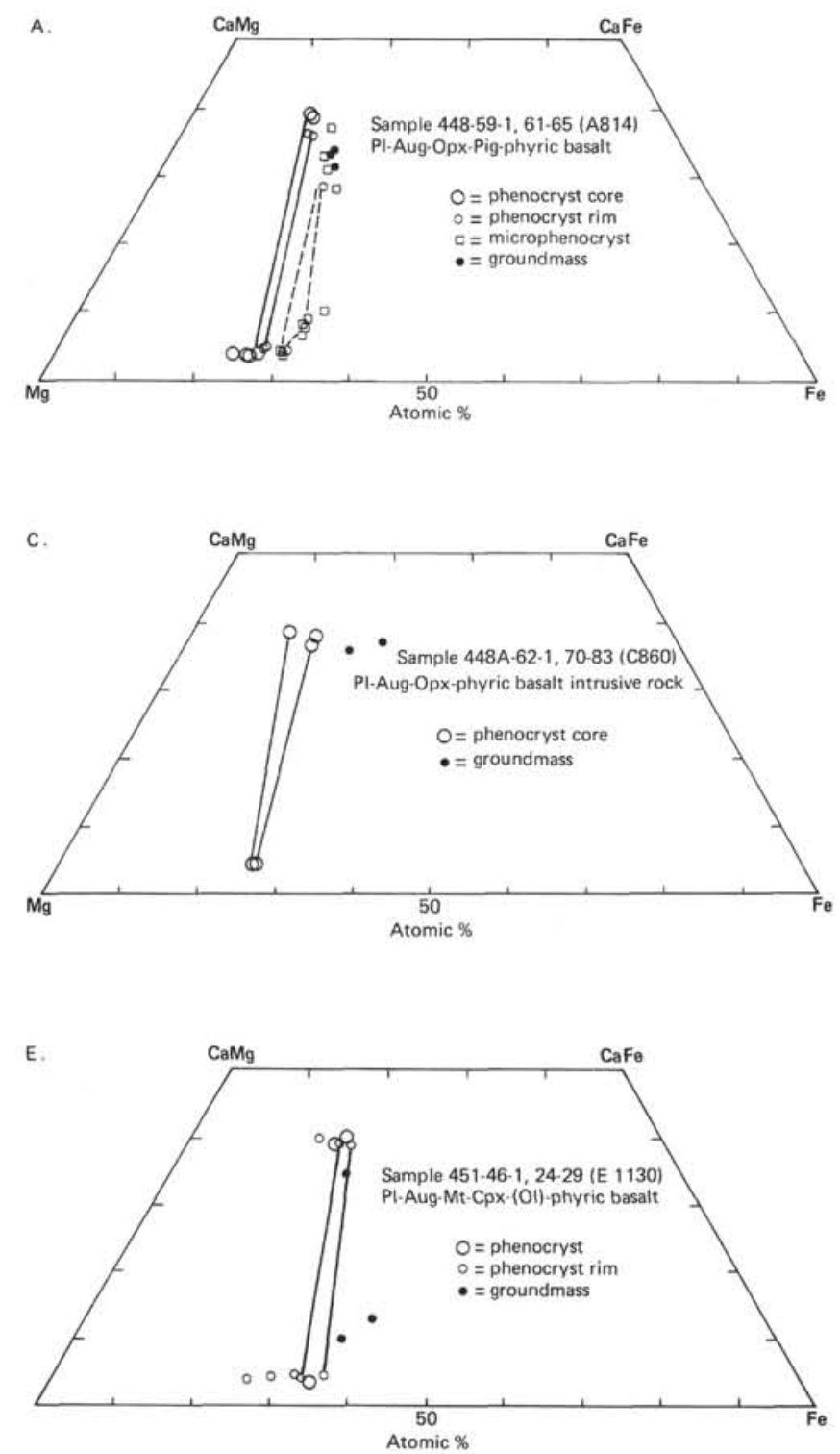

The petrology of the six samples used for these studies is described in the following report. Microprobe studies of these rocks were carried out on plagioclase, titanomagnetite, orthopyroxene, and clinopyroxene; selected results are presented in Tables 1 through 6 and plotted in Figure 1.

\section{Plagioclase-Augite-Bronzite-Pigeonite-Phyric Basaltic Glass (Rock A814) and Bytownite-Augite-Bronzite- Phyric Basalt (Rock B815)}

The specimens are from the upper chilled glassy marginal zone (Rock A814) (Table 1) and interior zone (Rock B815) (Table 2) of a massive lava flow more than 3 meters thick from Hole 448-Samples 448-59-1, 61-65 $\mathrm{cm}$ (Rock A814) and 117-120 cm (Rock B815). Megascopically, Rock B815 is vesicular and pale brown, with
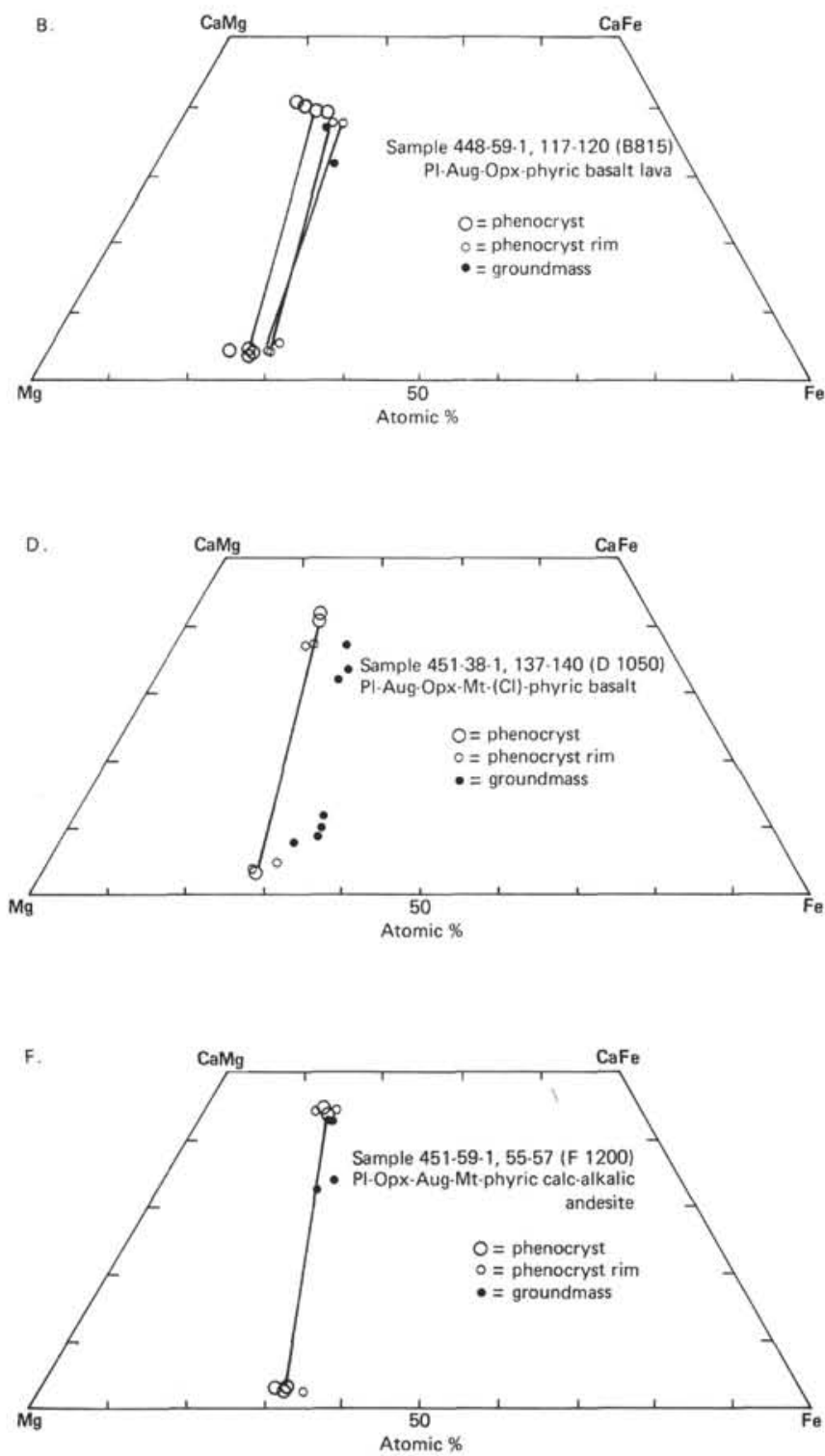

Figure 1. A. Ca-Mg-Fe plot of analyzed pyroxenes in Rock A814. B. Ca-Mg-Fe plot of analyzed pyroxenes in Rock B815. C. Ca-Mg-Fe plot of analyzed pyroxenes in Rock C860. D. Ca-Mg-Fe plot of analyzed pyroxenes in Rock D1050. E. Ca-Mg-Fe plot of analyzed pyroxenes in Rock E1130. F. Ca-Mg-Fe plot of analyzed pyroxenes in Rock F1200. 
Table 1. The pyroxene analyses of augite-bronzite-pigeonite-phyric basaltic glass (Rock A814) from Leg 59, Sample 448-59-1, 61-65 cm. a

\begin{tabular}{|c|c|c|c|c|c|c|c|c|c|c|c|}
\hline \multirow[b]{3}{*}{ Anal. No. ${ }^{b}$} & \multicolumn{5}{|c|}{ Orthopyroxene } & \multicolumn{5}{|c|}{ Augite } & \multirow{3}{*}{$\frac{\frac{\text { Pigeonite }}{\text { Gm. }}}{\text { A22 }}$} \\
\hline & \multicolumn{2}{|c|}{ Phenocryst core } & \multicolumn{3}{|c|}{ Phc. m. and microphc. } & \multirow{2}{*}{$\frac{\text { Phc.c. }}{\text { A17 }}$} & \multicolumn{3}{|c|}{ Phc. m. and microphc. } & \multirow{2}{*}{$\frac{\mathrm{Gm} .}{\mathrm{A} 21}$} & \\
\hline & A15 & A16 & Al1 & A18 & A13 & & $\mathrm{A} 12$ & A19 & Al4 & & \\
\hline $\mathrm{SiO}_{2}$ & 52.81 & 52.63 & 53.06 & 53.19 & 51.84 & 51.43 & 50.97 & 51.51 & 50.85 & 50.35 & 52.38 \\
\hline $\mathrm{Al}_{2} \mathrm{O}_{3}$ & 1.15 & 0.80 & 0.91 & 1.20 & 1.27 & 1.80 & 1.94 & 2.01 & 2.03 & 3.19 & 0.98 \\
\hline $\mathrm{TiO}_{2}$ & 0.16 & 0.18 & 0.16 & 0.23 & 0.24 & 0.31 & 0.36 & 0.27 & 0.34 & 0.55 & 0.27 \\
\hline $\mathrm{Cr}_{2} \mathrm{O}_{3}$ & 0.04 & 0.00 & 0.04 & 0.00 & 0.01 & 0.05 & 0.03 & 0.04 & 0.05 & 0.03 & 0.00 \\
\hline $\mathrm{FeO} *$ & 15.88 & 16.27 & 16.00 & 18.46 & 18.17 & 9.30 & 10.22 & 13.09 & 10.12 & 12.03 & 18.55 \\
\hline $\mathrm{MnO}$ & 0.37 & 0.34 & 0.39 & 0.36 & 0.44 & 0.25 & 0.33 & 0.22 & 0.26 & 0.28 & 0.33 \\
\hline $\mathrm{MgO}$ & 26.14 & 25.35 & 25.53 & 23.85 & 24.04 & 16.08 & 16.18 & 16.39 & 15.64 & 15.84 & 22.43 \\
\hline $\mathrm{CaO}$ & 2.01 & 2.11 & 2.22 & 2.40 & 2.36 & 18.83 & 18.54 & 14.85 & 19.06 & 16.62 & 3.99 \\
\hline $\mathrm{Na}_{2} \mathrm{O}$ & 0.04 & 0.02 & 0.06 & 0.11 & 0.04 & 0.19 & 0.21 & 0.22 & 0.25 & 0.20 & 0.13 \\
\hline Total & 98.60 & 97.70 & 98.37 & 99.80 & 98.41 & 98.24 & 98.78 & 98.60 & 98.60 & 99.09 & 99.06 \\
\hline \multicolumn{12}{|l|}{$0=6.000$} \\
\hline Si & 1.948 & 1.963 & 1.963 & 1.960 & 1.941 & 1.942 & 1.924 & 1.947 & 1.925 & 1.899 & 1.958 \\
\hline $\mathrm{Al}$ & 0.050 & 0.035 & 0.037 & 0.040 & 0.056 & 0.058 & 0.076 & 0.053 & 0.075 & 0.101 & 0.042 \\
\hline $\mathrm{Al}$ & 0.000 & 0.000 & 0.002 & 0.012 & 0.000 & 0.022 & 0.010 & 0.037 & 0.015 & 0.040 & 0.001 \\
\hline $\mathrm{Ti}$ & 0.004 & 0.005 & 0.004 & 0.006 & 0.007 & 0.009 & 0.010 & 0.008 & 0.010 & 0.016 & 0.008 \\
\hline $\mathrm{Cr}$ & 0.001 & 0.000 & 0.001 & 0.000 & 0.000 & 0.001 & 0.001 & 0.001 & 0.001 & 0.001 & 0.000 \\
\hline $\mathrm{Fe}$ & 0.490 & 0.507 & 0.495 & 0.569 & 0.569 & 0.294 & 0.323 & 0.414 & 0.320 & 0.379 & 0.580 \\
\hline $\mathrm{Mn}$ & 0.012 & 0.011 & 0.012 & 0.011 & 0.014 & 0.008 & 0.011 & 0.007 & 0.008 & 0.009 & 0.010 \\
\hline $\mathrm{Mg}$ & 1.437 & 1.409 & 1.407 & 1.310 & 1.341 & 0.905 & 0.910 & 0.924 & 0.882 & 0.890 & 1.250 \\
\hline $\mathrm{Ca}$ & 0.079 & 0.084 & 0.088 & 0.095 & 0.095 & 0.762 & 0.750 & 0.601 & 0.773 & 0.672 & 0.160 \\
\hline $\mathrm{Na}$ & 0.003 & 0.001 & 0.004 & 0.008 & 0.003 & 0.014 & 0.015 & 0.016 & 0.018 & 0.015 & 0.009 \\
\hline Z & 1.998 & 1.998 & 2.000 & 2.000 & 1.997 & 2.000 & 2.000 & 2.000 & 2.000 & 2.000 & 2.000 \\
\hline WXY & 2.026 & 2.018 & 2.015 & 2.011 & 2.029 & 2.015 & 2.030 & 2.008 & 2.029 & 2.022 & 2.018 \\
\hline \multicolumn{12}{|l|}{ Atomic $\%$} \\
\hline $\mathrm{Ca}$ & 4.0 & 4.2 & 4.4 & 4.8 & 4.7 & 38.9 & 37.8 & 31.0 & 39.1 & 34.6 & 8.0 \\
\hline $\mathrm{Mg}$ & 71.6 & 70.4 & 70.7 & 66.4 & 66.9 & 46.2 & 45.9 & 47.6 & 44.7 & 45.9 & 62.8 \\
\hline $\mathrm{Fe}$ & 24.4 & 25.4 & 24.9 & 28.8 & 28.4 & 15.0 & 16.3 & 21.3 & 16.2 & 19.5 & 29.1 \\
\hline $\begin{array}{l}\text { Contig. } \\
\text { Anal. No. }\end{array}$ & & A17 & A12 & & & A16 & A11 & & & & \\
\hline
\end{tabular}

Note: $\mathrm{FeO}^{*}$ indicates total $\mathrm{Fe}$ expressed as $\mathrm{FeO}$.

a Abbreviations often used in Tables 1 through 6 are: Phc. = phenocryst, m. = margin, microphc. = microphenocryst,

$\mathrm{Gm} .=$ groundmass, $\mathrm{Pig} .=$ pigeonite, $\mathrm{c} .=$ core .

b Anal. no. in Tables 1 through 7 and $9=$ the analysis number author uses for his data.

Contiguous-phase analyzed number. Each pair was used for temperature estimation.

Table 2. The pyroxene analyses of augite-bronzite-phyric tholeiitic basalt (Rock B815) from Leg 59, 448-59-1, 117-120 cm.

\begin{tabular}{|c|c|c|c|c|c|c|c|c|c|c|c|c|c|c|}
\hline \multirow[b]{3}{*}{ Anal. No. } & \multicolumn{8}{|c|}{ Orthopyroxene } & \multicolumn{6}{|c|}{ Augite } \\
\hline & \multicolumn{3}{|c|}{ Phenocryst core } & \multicolumn{5}{|c|}{ Phenocryst margin and microphenocryst } & \multicolumn{2}{|c|}{ Phc. c. } & \multicolumn{3}{|c|}{ Phc. m. and microphc. } & \multirow{2}{*}{$\frac{\mathrm{Gm} .}{\mathrm{B} 21}$} \\
\hline & B08 & B10 & B12 & B13 & B16 & B17 & B23 & B24 & В09 & B11 & B15 & B18 & B22 & \\
\hline $\mathrm{SiO}_{2}$ & 54.00 & 53.20 & 52.68 & 52.13 & 52.79 & 52.55 & 52.37 & 52.35 & 51.30 & 50.09 & 51.59 & 51.15 & 50.75 & 51.52 \\
\hline $\mathrm{Al}_{2} \mathrm{O}_{3}$ & 1.10 & 1.19 & 1.17 & 1.73 & 1.65 & 1.65 & 1.62 & 1.40 & 2.00 & 2.53 & 1.94 & 2.60 & 2.38 & 1.93 \\
\hline $\mathrm{TiO}_{2}$ & 0.15 & 0.09 & 0.13 & 0.24 & 0.16 & 0.21 & 0.22 & 0.24 & 0.33 & 0.40 & 0.31 & 0.29 & 0.38 & 0.49 \\
\hline $\mathrm{Cr}_{2} \mathrm{O}_{3}$ & 0.04 & 0.04 & 0.05 & 0.03 & 0.04 & 0.03 & 0.00 & 0.02 & 0.08 & 0.05 & 0.08 & 0.11 & 0.00 & 0.04 \\
\hline $\mathrm{FeO}^{*}$ & 15.12 & 16.62 & 17.94 & 18.23 & 16.38 & 16.61 & 18.27 & 16.30 & 10.06 & 12.40 & 9.43 & 8.03 & 11.25 & 11.49 \\
\hline $\mathrm{MnO}$ & 0.30 & 0.36 & 0.36 & 0.38 & 0.35 & 0.35 & 0.41 & 0.38 & 0.23 & 0.27 & 0.23 & 0.19 & 0.28 & 0.28 \\
\hline $\mathrm{MgO}$ & 26.43 & 25.58 & 24.50 & 23.23 & 25.24 & 24.89 & 24.28 & 25.16 & 15.57 & 14.38 & 16.21 & 16.30 & 15.05 & 15.14 \\
\hline $\mathrm{CaO}$ & 2.04 & 2.08 & 2.06 & 2.60 & 1.96 & 2.15 & 2.04 & 2.36 & 19.20 & 18.00 & 19.19 & 19.90 & 18.76 & 17.59 \\
\hline $\mathrm{Na}_{2} \mathrm{O}$ & 0.02 & 0.01 & 0.02 & 0.03 & 0.04 & 0.03 & 0.04 & 0.05 & 0.20 & 0.22 & 0.20 & 0.17 & 0.21 & 0.23 \\
\hline Total & 99.20 & 99.17 & 98.91 & 98.60 & 98.61 & 98.47 & 99.25 & 98.26 & 98.97 & 98.34 & 99.18 & 98.74 & 99.06 & 98.71 \\
\hline \multicolumn{15}{|l|}{$O=6.000$} \\
\hline $\mathrm{Si}$ & 1.967 & 1.955 & 1.954 & 1.946 & 1.949 & 1.946 & 1.940 & 1.944 & 1.932 & 1.916 & 1.933 & 1.917 & 1.919 & 1.948 \\
\hline Al & 0.033 & 0.045 & 0.046 & 0.054 & 0.051 & 0.054 & 0.060 & 0.056 & 0.068 & 0.084 & 0.067 & 0.083 & $0.08 \mathrm{I}$ & 0.052 \\
\hline $\mathrm{Al}$ & 0.014 & 0.007 & 0.005 & 0.022 & 0.020 & 0.018 & 0.011 & 0.005 & 0.021 & 0.030 & 0.018 & 0.031 & 0.025 & 0.034 \\
\hline $\mathrm{Ti}$ & 0.004 & 0.002 & 0.004 & 0.007 & 0.004 & 0.006 & 0.006 & 0.007 & 0.009 & 0.012 & 0.009 & 0.008 & 0.011 & 0.014 \\
\hline $\mathrm{Cr}$ & 0.001 & 0.001 & 0.001 & 0.001 & 0.001 & 0.001 & 0.000 & 0.001 & 0.002 & 0.002 & 0.002 & 0.003 & 0.000 & 0.001 \\
\hline $\mathrm{Fe}$ & 0.461 & 0.511 & 0.557 & 0.569 & 0.506 & 0.515 & 0.566 & 0.506 & 0.317 & 0.397 & 0.295 & 0.252 & 0.356 & 0.363 \\
\hline $\mathrm{Mn}$ & 0.009 & 0.011 & 0.011 & 0.012 & 0.011 & 0.011 & 0.013 & 0.012 & 0.007 & 0.009 & 0.007 & 0.006 & 0.009 & 0.009 \\
\hline $\mathrm{Mg}$ & 1.435 & 1.401 & 1.355 & 1.293 & 1.389 & 1.374 & 1.341 & 1.392 & 0.874 & 0.820 & 0.905 & 0.910 & 0.848 & 0.853 \\
\hline $\mathrm{Ca}$ & 0.080 & 0.082 & 0.082 & 0.104 & 0.078 & 0.085 & 0.081 & 0.094 & 0.775 & 0.738 & 0.770 & 0.799 & 0.760 & 0.712 \\
\hline $\mathrm{Na}$ & 0.001 & 0.001 & 0.001 & 0.002 & 0.003 & 0.002 & 0.003 & 0.004 & 0.015 & 0.016 & 0.015 & 0.012 & 0.015 & 0.017 \\
\hline Z & 2.000 & 2.000 & 2.000 & 2.000 & 2.000 & 2.000 & 2.000 & 2.000 & 2.000 & 2.000 & 2.000 & 2.000 & 2.000 & 2.000 \\
\hline WXY & 2.005 & 2.016 & 2.016 & 2.010 & 2.012 & 2.012 & 2.020 & 2.020 & 2.020 & 2.023 & 2.022 & 2.022 & 2.025 & 2.003 \\
\hline \multicolumn{15}{|l|}{ Atomic $\%$} \\
\hline $\mathrm{Ca}$ & 4.0 & 4.1 & 4.1 & 5.3 & 3.9 & 4.3 & 4.1 & 4.7 & 39.4 & 37.7 & 39.1 & 40.7 & 38.7 & 36.9 \\
\hline $\mathrm{Mg}$ & 72.7 & 70.3 & 68.0 & 65.8 & 70.4 & 69.6 & 67.4 & 69.9 & 44.5 & 42.0 & 45.9 & 46.4 & 43.2 & 44.2 \\
\hline $\mathrm{Fe}$ & 23.3 & 25.6 & 27.9 & 29.0 & 25.6 & 26.1 & 28.5 & 25.4 & 16.1 & 20.3 & 15.0 & 12.8 & 18.1 & 18.8 \\
\hline $\begin{array}{l}\text { Contig. } \\
\text { Anal. No. }\end{array}$ & & B09 & B11 & & B15 & & B22 & & B10 & B12 & B16 & & B23 & \\
\hline
\end{tabular}

Note: See Table 1 for meaning of abbreviations. 
rare phenocrysts of plagioclase (up to $3 \mathrm{~mm}$ in diameter) and indistinct black pyroxene. Scattered vesicles (up to 2 $\mathrm{mm}$ ) are partly filled with calcite and zeolites. Rock A814 has a compact, fresh, black glass margin up to 1.5 $\mathrm{cm}$ thick containing sparse plagioclase phenocrysts.

Thin-section observations of Rock B815 show that the rock consists of phenocrysts and microphenocrysts of plagioclase (15 volume \%, exclusive of vesicles, $0.4-3.0 \mathrm{~mm}$ long), augite $(2 \%, 0.4-1.5 \mathrm{~mm})$, and orthopyroxene $(1 \%, 0.5-2.6 \mathrm{~mm})$ with a hyalophitic groundmass of plagioclase $(25 \%, 0.5-0.1 \mathrm{~mm})$, augite $(20 \%$, $0.05-0.1 \mathrm{~mm})$, titanomagnetite $(7 \%, 0.01-0.05 \mathrm{~mm})$, and devitrified dark brown glass $(30 \%)$. Scattered irregular vesicles $(0.2-3 \mathrm{~mm}$, one third in volume) are usually not filled with secondary minerals.

Plagioclase phenocrysts are euhedral to subhedral and commonly contain rounded brown to black altered glass. Their composition ranges from $A_{88} A_{12}$ to $A_{80}$ $\mathrm{Ab}_{20}$ (molar ratios) and from $\mathrm{An}_{67} \mathrm{Ab}_{33}$ to $\mathrm{An}_{62} \mathrm{Ab}_{38}$ in the cores of phenocrysts and groundmass plagioclase, respectively; both zone toward $A_{57} A_{b_{43}}$ in their thin rims. On the other hand, rarely observed anhedral, rounded plagioclase is more calcic $\left(\mathrm{An}_{92} \mathrm{Ab}_{8}-\mathrm{An}_{90} \mathrm{Ab} \mathrm{b}_{10}\right)$ and contains abundant glass inclusions. These characteristics indicate that the calcic plagioclases are xenocrysts.

Augite phenocrysts are euhedral to subhedral and commonly glomerophyric with plagioclase and augite itself. As shown in Figure 1B, the reverse zoning (increasing $\mathrm{Mg} / \mathrm{Fe}$ ratio) is observed in the augite crystallization sequence, that is, chemical composition of augite varies from large phenocryst cores $\left(\mathrm{Ca}_{39}\right.$ $\mathrm{Mg}_{45} \mathrm{Fe}_{16}$ in atomic ratio) through small phenocryst cores $\left(\mathrm{Ca}_{38} \mathrm{Mg}_{42} \mathrm{Fe}_{20}\right)$ with relatively low $\mathrm{Mg} / \mathrm{Fe}$ ratios, and through microphenocrysts $\left(\mathrm{Ca}_{41} \mathrm{Mg}_{46} \mathrm{Fe}_{13}\right)$ with relatively high $\mathrm{Mg} / \mathrm{Fe}$ ratios to groundmass augite crystals $\left(\mathrm{Ca}_{32} \mathrm{Mg}_{46} \mathrm{Fe}_{22}\right)$ with relatively low $\mathrm{Mg} / \mathrm{Fe}$ and $\mathrm{Ca} /(\mathrm{Mg}+\mathrm{Fe}+\mathrm{Ca})$ ratios.

Bronzite phenocrysts are euhedral to subhedral, sometimes glomerophyric with augite, and always rimmed by zoned augite. The chemical composition of bronzite varies from large phenocryst cores $\left(\mathrm{Ca}_{4} \mathrm{Mg}_{73}\right.$ $\left.\mathrm{Fe}_{23}\right)$ through small phenocryst cores $\left(\mathrm{Ca}_{4} \mathrm{Mg}_{70} \mathrm{Fe}_{26}\right)$ with relatively low $\mathrm{Mg} / \mathrm{Fe}$ ratios, and through microphenocrysts $\left(\mathrm{Ca}_{4.5} \mathrm{Mg}_{70} \mathrm{Fe}_{25.5}\right)$ with reversed trends to $\mathrm{Mg} / \mathrm{Fe}$ ratios, to phenocryst margins $\left(\mathrm{Ca}_{5} \mathrm{Mg}_{66} \mathrm{Fe}_{29}\right)$ with relatively low $\mathrm{Mg} / \mathrm{Fe}$ ratios. Orthopyroxene is not observed in the groundmass.

The chemical composition of groundmass titanomagnetite varies from Usp ${ }_{33} \mathrm{Mt}_{67}$ (ulvospinel and magnetite molar ratio) with relatively large grains about $0.02 \mathrm{~mm}$ long, to $\mathrm{Usp}_{55} \mathrm{Mt}_{45}$ with grains smaller than about 0.01 $\mathrm{mm}$.

Under the microscope, the glassy rock (A814) consists of phenocrysts and microphenocrysts of plagioclase $(10 \%, 0.2-3 \mathrm{~mm})$, augite $(3 \%, 0.1-0.5 \mathrm{~mm})$, and bronzite $(1 \%, 0.1-0.7 \mathrm{~mm})$, and microphenocrysts of pigeonite $(1 \%, 0.1-0.3 \mathrm{~mm})$ with a groundmass of plagioclase $(3 \%, 0.01-0.1 \mathrm{~mm})$, augite $(1 \%, 0.01-0.03$ $\mathrm{mm}$ ), pigeonite (trace, $0.01-0.03 \mathrm{~mm}$ ), and scarcely devitrified pale brown clear glass $(80 \%)$.
Plagioclase phenocrysts are euhedral to subhedral and rarely contain brown to black relatively fresh glasses. Groundmass plagioclase crystals are lathshaped in most cases, but have stout prismatic forms in a few large crystals.

Augite phenocrysts are euhedral to subhedral. The chemical composition of augite varies from phenocryst cores $\left(\mathrm{Ca}_{43} \mathrm{Mg}_{48} \mathrm{Fe}_{9}\right)$ with relatively high $\mathrm{Mg} / \mathrm{Fe}$ ratios, through phenocryst margins or microphenocrysts $\left(\mathrm{Ca}_{36}\right.$ $\mathrm{Mg}_{47} \mathrm{Fe}_{17}-\mathrm{Ca}_{29} \mathrm{Mg}_{49} \mathrm{Fe}_{22}$ ) with relatively low $\mathrm{Mg} / \mathrm{Fe}$ and $\mathrm{Ca} /(\mathrm{Ca}+\mathrm{Mg}+\mathrm{Fe})$ ratios, to groundmass crystals $\left(\mathrm{Ca}_{33} \mathrm{Mg}_{46} \mathrm{Fe}_{21}\right)$. This represents an intensive quenched crystallization trend.

Orthopyroxene phenocrysts are euhedral to subhedral, and usually have no clinopyroxene rim. Although some orthopyroxene phenocrysts have a relatively thick augite rim, pigeonite rims are very rare. The chemical composition of Ca-poor pyroxene varies from bronzite phenocryst cores $\left(\mathrm{Ca}_{4} \mathrm{Mg}_{73} \mathrm{Fe}_{23}\right)$ with relatively high $\mathrm{Mg} / \mathrm{Fe}$ ratios, through phenocryst margins or microphenocrysts $\left(\mathrm{Ca}_{4} \mathrm{Mg}_{66} \mathrm{Fe}_{30}\right)$ with normal trends to $\mathrm{Mg} / \mathrm{Fe}$ ratios, to pigeonite microphenocrysts $\left(\mathrm{Ca}_{8} \mathrm{Mg}_{62}\right.$ $\mathrm{Fe}_{30}$ ). These pyroxene crystallization sequences indicate that three pyroxenes (augite + orthopyroxene + pigeonite) coprecipitated in equilibrium in the microphenocryst stage. Opaque minerals are not observed.

\section{Anorthite-Bronzite-Augite Phyric Basalt (Rock C860)}

This specimen, from the interior zone of a massive dike with a thickness of more than 2 meters, was collected from Hole 448A (Sample 448A-62-1, 70-83 cm) (Table 3). Megascopically, the rock is compact and pale greenish gray, with phenocrysts of abundant plagioclase (up to $4 \mathrm{~mm}$ ) and distinct black pyroxene (up to $3 \mathrm{~mm}$ ).

Thin-section observations show that the rock consists of phenocrysts and microphenocrysts of plagioclase $(40 \%, 0.5-3 \mathrm{~mm})$, orthopyroxene $(3 \%, 0.5-2 \mathrm{~mm})$, and augite $(2 \%, 0.5-1.5 \mathrm{~mm})$, with an intergranular groundmass of plagioclase $(15 \%, 0.1-0.3 \mathrm{~mm})$, augite $(15 \%$, $0.05-0.2 \mathrm{~mm})$, magnetite $(5 \%, 0.02-0.1 \mathrm{~mm})$, and altered pale brown glass $(20 \%)$.

Plagioclase phenocrysts are euhedral and rarely glomerophyric. The composition ranges from $\mathrm{An}_{93} \mathrm{Ab}_{7}$ to $A n_{89} A b_{11}$ and $A n_{70} A b_{30}$ to $A n_{67} A_{33}$ in the core of phenocrysts and groundmass plagioclase, respectively; both are zoned toward $\mathrm{An}_{53} \mathrm{Ab}_{47}$ in their thin rims. Very sodic rims $\left(\mathrm{An}_{33} \mathrm{Ab}_{63} \mathrm{Or}_{4}\right)$ are rarely observed.

Bronzite phenocrysts are subhedral and sometimes partially or wholly replaced by clay minerals, especially in the margins. Orthopyroxene and pigeonite are not observed in the groundmass. Phenocrysts of bronzite are very homogeneous $\left(\mathrm{Ca}_{4.5} \mathrm{Mg}_{70.5} \mathrm{Fe}_{25}\right)$ and free from augite or pigeonite rims.

Augite phenocrysts are euhedral to subhedral and sometimes glomerophyric with orthopyroxene and plagioclase. The chemical composition of augite varies from phenocryst cores $\left(\mathrm{Ca}_{38} \mathrm{Mg}_{49} \mathrm{Fe}_{13}\right)$ with relatively high $\mathrm{Mg} / \mathrm{Fe}$ ratios, through phenocryst margins $\left(\mathrm{Ca}_{38}\right.$ $\left.\mathrm{Mg}_{46} \mathrm{Fe}_{16}\right)$ with varying $\mathrm{Mg} / \mathrm{Fe}$ ratios, to groundmass augite crystals $\left(\mathrm{Ca}_{37} \mathrm{Mg}_{38} \mathrm{Fe}_{25}\right)$ with relatively low $\mathrm{Mg} / \mathrm{Fe}$ ratios. 
Table 3. The pyroxene analyses of bronzite-augite-phyric tholeiitic basalt (Rock C860) from Leg 59, Sample 448A-62-1, 70-83 cm.

\begin{tabular}{|c|c|c|c|c|c|c|}
\hline \multirow[b]{3}{*}{ Anal. No. } & \multirow{2}{*}{\multicolumn{2}{|c|}{$\frac{\text { Orthopyroxene }}{\text { Phenocryst core }}$}} & \multicolumn{4}{|c|}{ Augite } \\
\hline & & & \multicolumn{2}{|c|}{ Phenocryst core } & \multirow{2}{*}{$\frac{\text { Phc. m. }}{\cos }$} & \multirow{2}{*}{$\frac{\mathrm{Gm} .}{\mathrm{C} 07}$} \\
\hline & $\mathrm{CO1}$ & $\mathrm{CO2}$ & $\mathrm{CO} 3$ & $\mathrm{CO} 4$ & & \\
\hline $\mathrm{SiO}_{2}$ & 53.27 & 53.29 & 51.45 & 51.59 & 51.54 & 49.01 \\
\hline $\mathrm{Al}_{2} \mathrm{O}_{3}$ & 0.94 & 1.60 & 2.37 & 2.49 & 2.01 & 3.00 \\
\hline $\mathrm{TiO}_{2}$ & 0.17 & 0.19 & 0.38 & 0.35 & 0.40 & 0.78 \\
\hline $\mathrm{Cr}_{2} \mathrm{O}_{3}$ & 0.01 & 0.08 & 0.04 & 0.24 & 0.04 & 0.00 \\
\hline $\mathrm{FeO}^{*}$ & 16.24 & 15.90 & 10.18 & 7.90 & 10.21 & 15.16 \\
\hline $\mathrm{MnO}$ & 0.38 & 0.35 & 0.24 & 0.21 & 0.27 & 0.39 \\
\hline $\mathrm{MgO}$ & 25.39 & 25.11 & 16.17 & 17.04 & 15.88 & 12.76 \\
\hline $\mathrm{CaO}$ & 2.16 & 2.22 & 17.49 & 18.67 & 18.42 & 17.25 \\
\hline $\mathrm{Na}_{2} \mathrm{O}$ & 0.02 & 0.03 & 0.20 & 0.18 & 0.21 & 0.23 \\
\hline Total & 98.58 & 98.77 & 98.52 & 98.67 & 98.98 & 98.58 \\
\hline \multicolumn{7}{|l|}{$O=6.000$} \\
\hline $\mathrm{Si}$ & 1.996 & 1.959 & 1.936 & 1.926 & 1.937 & 1.894 \\
\hline $\mathrm{Al}$ & 0.034 & 0.041 & 0.064 & 0.074 & 0.063 & 0.106 \\
\hline $\mathrm{Al}$ & 0.007 & 0.028 & 0.041 & 0.035 & 0.026 & 0.031 \\
\hline $\mathrm{Ti}$ & 0.005 & 0.005 & 0.011 & 0.010 & 0.011 & 0.023 \\
\hline $\mathrm{Cr}$ & 0.000 & 0.002 & 0.001 & 0.007 & 0.001 & 0.000 \\
\hline $\mathrm{Fe}$ & 0.501 & 0.489 & 0.320 & 0.247 & 0.321 & 0.490 \\
\hline Mn & 0.012 & 0.011 & 0.008 & 0.007 & 0.009 & 0.013 \\
\hline $\mathrm{Mg}$ & 1.397 & 1.376 & 0.907 & 0.948 & 0.890 & 0.735 \\
\hline $\mathrm{Ca}$ & 0.085 & 0.087 & 0.705 & 0.747 & 0.742 & 0.714 \\
\hline $\mathrm{Na}$ & 0.001 & 0.002 & 0.015 & 0.013 & 0.015 & 0.017 \\
\hline Z & 2.000 & 2.000 & 2.000 & 2.000 & 2.000 & 2.000 \\
\hline WXY & 2.009 & 2.001 & 2.008 & 2.013 & 2.014 & 2.023 \\
\hline \multicolumn{7}{|l|}{ Atomic \% } \\
\hline $\mathrm{Ca}$ & 4.3 & 4.5 & 36.5 & 38.5 & 38.0 & 36.8 \\
\hline $\mathrm{Mg}$ & 70.4 & 70.5 & 46.9 & 48.8 & 45.6 & 37.9 \\
\hline $\mathrm{Fe}$ & 25.3 & 25.0 & 16.6 & 12.7 & 16.4 & 25.3 \\
\hline Contig. & $\mathrm{C} 03$ & $\mathrm{CO} 3$ & $\mathrm{CO1}$ & $\mathrm{C} 02$ & & \\
\hline Anal. No. & & $\mathrm{CO} 4$ & $\mathrm{CO} 2$ & & & \\
\hline
\end{tabular}

Note: See Table 1 for meaning of abbreviations.
The chemical composition of groundmass titanomagnetite crystals varies from Usp ${ }_{50} \mathrm{Mt}_{50}$ in relatively large grains about $0.05 \mathrm{~mm}$ long to Usp ${ }_{58} \mathrm{Mt}_{42}$ in small grains about $0.02 \mathrm{~mm}$ long.

\section{Anorthite-Augite-Bronzite-Titanomagnetite- (Olivine)-Phyric Basalt (Rock D1050)}

The specimen is a clast in the volcaniclastic breccia from Hole 451 (Sample 451-38-1, 137-140 cm). Megascopically, the rock is compact and slightly greenish dark gray, with phenocrysts of abundant plagioclases (up to $5 \mathrm{~mm}$ ) and a few pyroxenes (Table 4).

Microscopic examination of thin sections shows that the rock consists of phenocrysts and microphenocrysts of plagioclase $(35 \%, 0.4-7 \mathrm{~mm})$, augite $(3 \%, 0.4-3.0$ $\mathrm{mm})$, orthopyroxene $(2 \%, 0.4-2.0 \mathrm{~mm})$, titanomagnetite $(1 \%, 0.05-0.1 \mathrm{~mm})$, and pseudomorphed olivine $(1 \%, 0.4-0.8 \mathrm{~mm})$, with a hyalophitic groundmass of plagioclase $(10 \%, 0.01-0.1 \mathrm{~mm})$, augite $(10 \%, 0.01-0.1$ $\mathrm{mm})$, titanomagnetite $(5 \%, 0.01-0.05 \mathrm{~mm})$, pigeonite (trace, $<0.1 \mathrm{~mm}$ ), and devitrified yellow glass $(40 \%)$.

Two types of plagioclase phenocrysts can be recognized by the resorption structure in their cores: plagioclase phenocrysts without resorption are euhedral and have very large sizes (up to $7 \mathrm{~mm}$ ); those with resorption are subhedral to euhedral, small in size (up to 3 $\mathrm{mm}$ ), and show a honeycombed structure in the core, followed by overgrowths of more sodic plagioclase. In the plagioclase-phenocryst cores with and without re-

Table 4. The pyroxene analyses of augite-bronzite-phyric tholeiitic basalt (Rock D1050) from Leg 59, Sample 451-38-1, 137-140 cm.

\begin{tabular}{|c|c|c|c|c|c|c|c|c|c|c|}
\hline \multirow[b]{3}{*}{ Anal. No. } & \multicolumn{3}{|c|}{ Orthopyroxene } & \multicolumn{5}{|c|}{ Augite } & \multirow{2}{*}{\multicolumn{2}{|c|}{$\begin{array}{c}\text { Pigeonite } \\
\text { Groundmass }\end{array}$}} \\
\hline & \multirow{2}{*}{$\frac{\text { Phc. c. }}{\text { D13 }}$} & \multicolumn{2}{|c|}{$\begin{array}{l}\text { Phc. m. and } \\
\text { microphc. }\end{array}$} & \multicolumn{2}{|c|}{ Phenocryst core } & \multicolumn{2}{|c|}{$\begin{array}{l}\text { Phc. m. and } \\
\text { microphc. }\end{array}$} & \multirow{2}{*}{$\frac{\text { Gm. }}{\mathrm{D} 16}$} & & \\
\hline & & D19 & D14 & D12 & D23 & D18 & D15 & & D17 & D21 \\
\hline $\mathrm{SiO}_{2}$ & 52.28 & 52.61 & 52.04 & 49.72 & 49.70 & 50.83 & 50.22 & 49.59 & 52.38 & 51.23 \\
\hline $\mathrm{Al}_{2} \mathrm{O}_{3}$ & 1.49 & 1.40 & 1.05 & 3.15 & 3.37 & 1.98 & 2.60 & 3.09 & 0.77 & 1.20 \\
\hline $\mathrm{TiO}_{2}$ & 0.11 & 0.13 & 0.30 & 0.36 & 0.44 & 0.28 & 0.36 & 0.63 & 0.18 & 0.20 \\
\hline $\mathrm{Cr}_{2} \mathrm{O}_{3}$ & 0.00 & 0.00 & 0.00 & 0.00 & 0.00 & 0.01 & 0.01 & 0.00 & 0.00 & 0.00 \\
\hline $\mathrm{FeO}{ }^{*}$ & 17.04 & 17.11 & 18.34 & 10.33 & 9.87 & 10.60 & 10.94 & 13.39 & 19.91 & 19.02 \\
\hline $\mathrm{MnO}$ & 0.46 & 0.44 & 0.51 & 0.28 & 0.29 & 0.31 & 0.34 & 0.45 & 0.60 & 0.67 \\
\hline $\mathrm{MgO}$ & 24.86 & 25.34 & 23.83 & 14.81 & 14.67 & 16.29 & 15.93 & 14.12 & 20.35 & 22.25 \\
\hline $\mathrm{CaO}$ & 1.77 & 1.99 & 2.34 & 19.35 & 19.65 & 18.03 & 18.05 & 17.62 & 4.12 & 3.85 \\
\hline $\mathrm{Na}_{2} \mathrm{O}$ & 0.04 & 0.05 & 0.04 & 0.29 & 0.31 & 0.21 & 0.22 & 0.29 & 0.09 & 0.06 \\
\hline Total & 98.05 & 99.07 & 98.45 & 98.29 & 98.30 & 98.54 & 98.67 & 99.18 & 98.40 & 98.48 \\
\hline \multicolumn{11}{|l|}{$\mathrm{O}=6.000$} \\
\hline $\mathrm{Si}$ & 1.948 & 1.942 & 1.949 & 1.894 & 1.890 & 1.924 & 1.903 & 1.891 & 1.984 & 1.937 \\
\hline $\mathrm{Al}$ & 0.052 & 0.058 & 0.046 & 0.106 & 0.110 & 0.076 & 0.097 & 0.109 & 0.016 & 0.053 \\
\hline $\mathrm{Al}$ & 0.014 & 0.003 & 0.000 & 0.035 & 0.042 & 0.012 & 0.019 & 0.029 & 0.019 & 0.000 \\
\hline $\mathrm{Ti}$ & 0.003 & 0.004 & 0.008 & 0.010 & 0.013 & 0.008 & 0.010 & 0.018 & 0.005 & 0.006 \\
\hline $\mathrm{Cr}$ & 0.000 & 0.000 & 0.000 & 0.000 & 0.000 & 0.000 & 0.000 & 0.000 & 0.000 & 0.000 \\
\hline $\mathrm{Fe}$ & 0.531 & 0.528 & 0.574 & 0.329 & 0.314 & 0.336 & 0.347 & 0.427 & 0.631 & 0.601 \\
\hline $\mathrm{Mn}$ & 0.015 & 0.014 & 0.016 & 0.009 & 0.009 & 0.010 & 0.011 & 0.015 & 0.019 & 0.021 \\
\hline $\mathrm{Mg}$ & 1.381 & 1.394 & 1.330 & 0.841 & 0.832 & 0.919 & 0.900 & 0.802 & 1.149 & 1.254 \\
\hline $\mathrm{Ca}$ & 0.071 & 0.079 & 0.094 & 0.790 & 0.801 & 0.731 & 0.733 & 0.720 & 0.167 & 0.156 \\
\hline $\mathrm{Na}$ & 0.003 & 0.004 & 0.003 & 0.021 & 0.023 & 0.015 & 0.016 & 0.021 & 0.007 & 0.004 \\
\hline Z & 2.000 & 2.000 & 1.995 & 2.000 & 2.000 & 2.000 & 2.000 & 2.000 & 2.000 & 1.990 \\
\hline WXY & 2.017 & 2.025 & 2.026 & 2.036 & 2.033 & 2.032 & 2.036 & 2.033 & 1.997 & 2.043 \\
\hline \multicolumn{11}{|l|}{ Atomic $\%$} \\
\hline $\mathrm{Ca}$ & 3.6 & 3.9 & 4.7 & 40.3 & 41.1 & 36.8 & 37.0 & 36.9 & 8.6 & 7.8 \\
\hline $\mathrm{Mg}$ & 69.6 & 69.7 & 66.6 & 42.9 & 42.7 & 46.3 & 45.5 & 41.2 & 59.0 & 62.3 \\
\hline $\mathrm{Fe}$ & 26.8 & 26.4 & 28.7 & 16.8 & 16.1 & 16.9 & 17.5 & 21.9 & 32.4 & 29.9 \\
\hline $\begin{array}{l}\text { Contig. } \\
\text { Anal. No. }\end{array}$ & D12 & D18 & D15 & D13 & & D19 & D14 & & & \\
\hline
\end{tabular}

Note: See Table 1 for meaning of abbreviations. 
sorption, the compositions are near $\mathrm{An}_{85} \mathrm{Ab}_{15}$ and $\mathrm{An}_{95} \mathrm{Ab}_{5}$ to $\mathrm{An}_{92} \mathrm{Ab}_{8}$ (sodic anorthite), respectively. Both phenocrysts strongly zone toward $\mathrm{An}_{67} \mathrm{Ab}_{33}$ near their margins. Groundmass plagiocase has a composition range of $\mathrm{An}_{66} \mathrm{Ab}_{34}$ to $\mathrm{An}_{60} \mathrm{Ab}_{40}$.

Augite phenocrysts are anhedral and contain titanomagnetite and altered, brown, spherical glass inclusions. Augite crystals have chemical compositions of $\mathrm{Ca}_{40} \mathrm{Mg}_{43} \mathrm{Fe}_{17}$ and $\mathrm{Ca}_{37} \mathrm{Mg}_{41} \mathrm{Fe}_{22}$ for phenocrysts and groundmass, respectively.

Bronzite phenocrysts are subhedral to anhedral, have only a few clinopyroxene rims, and commonly contain rounded titanomagnetite inclusions. Bronzite phenocrysts are homogeneous $\left(\mathrm{Ca}_{3.5} \mathrm{Mg}_{69.5} \mathrm{Fe}_{27}\right)$ in the core and zone slightly toward the margin $\left(\mathrm{Ca}_{4.5} \mathrm{Mg}_{70} \mathrm{Fe}_{26.5}\right)$.

Titanomagnetite phenocrysts are subhedral to anhedral and free of exsolution. The composition of titanomagnetite ranges from Usp ${ }_{18} \mathrm{Mt}_{82}$ to $\mathrm{Usp}_{22} \mathrm{Mt}_{78}$ for phenocrysts and is about $\mathrm{Usp}_{25} \mathrm{Mt}_{75}$ for the groundmass.

Groundmass pigeonites are subhedral and show small variations in composition between grains, as shown in Figure 1D. The most magnesian pigeonite in the thin section has a composition of $\mathrm{Ca}_{8} \mathrm{Mg}_{62} \mathrm{Fe}_{30}$.

\section{Bytownite-Augite-Titanomagnetite-Hypersthene- (Olivine)-Phyric Basalt (Rock E1130)}

The specimen is a clast in the very coarse volcaniclastic conglomerate from Hole 451 (Sample 451-46-1, $24-29 \mathrm{~cm})$. Megascopically, the rock is vesicular and reddish brown, with phenocrysts of abundant plagio- clase (up to $3 \mathrm{~mm}$ ) and distinct black pyroxene (up to 1 $\mathrm{mm}$ ) (Table 5). It shows some resemblance to the reddish brown surface of the plagioclase-two-pyroxenephyric andesite lava, which is very common in calcalkalic volcanoes of island arcs.

Microscopic examination of thin section shows that the rock consists of phenocrysts and microphenocrysts of plagioclase $(30 \%, 0.5-6 \mathrm{~mm})$, augite $(3 \%, 0.5-2.0$ $\mathrm{mm})$, titanomagnetite $(2 \%, 0.2-0.7 \mathrm{~mm})$, orthopyroxene $(1 \%, 0.2-1.5 \mathrm{~mm})$, and pseudomorphous olivine (trace, $0.5-2.5 \mathrm{~mm}$ ), with a hyalophitic groundmass of plagioclase $(15 \%, 0.02-0.4 \mathrm{~mm})$, augite $(5 \%, 0.02-0.3$ $\mathrm{mm})$, magnetite $(5 \%, 0.01-0.05 \mathrm{~mm})$, pigeonite (trace, $<0.05 \mathrm{~mm}$ ), and devitrified altered brown glass $(40 \%)$.

Two types of plagioclase phenocrysts are recognized; one is clear, and the other contains dusty inclusions in the core (followed by a very thin overgrowth of more sodic plagioclase). Both plagioclases are euhedral to subhedral. Their composition ranges from $\mathrm{An}_{93} \mathrm{Ab}_{7}$ to $A n_{90} A b_{10}$ and from $A n_{86} A b_{14}$ to $A n_{80} A b_{20}$ in cores with and without dusty inclusions, respectively. Both phenocrysts strongly zone toward $\mathrm{An}_{62} \mathrm{Ab}_{38}$ in the margins. Groundmass plagioclase has a composition range from $\mathrm{An}_{67} \mathrm{Ab}_{33}$ to $\mathrm{An}_{55} \mathrm{Ab}_{45}$.

Augite phenocrysts are subhedral to anhedral and contain subhedral titanomagnetite inclusions. As shown in Figure 1E, the chemical composition of augite varies from phenocrysts $\left(\mathrm{Ca}_{39} \mathrm{Mg}_{42} \mathrm{Fe}_{19}\right)$ with relatively low $\mathrm{Mg} / \mathrm{Fe}$ ratios, through microphenocrysts $\left(\mathrm{Ca}_{40} \mathrm{Mg}_{44}\right.$ $\mathrm{Fe}_{16}$ ) with relatively high $\mathrm{Mg} / \mathrm{Fe}$ ratios, to groundmass augite crystals $\left(\mathrm{Ca}_{35} \mathrm{Mg}_{43} \mathrm{Fe}_{22}\right)$ with relatively low

Table 5. The pyroxene analyses of augite-hypersthene-phyric tholeitic basalt (Rock E1130) from Leg 59, Sample 451-46-1, 24-29 cm.

\begin{tabular}{|c|c|c|c|c|c|c|c|c|c|c|}
\hline \multirow[b]{3}{*}{ Anal. No. } & \multicolumn{4}{|c|}{ Orthopyroxene } & \multicolumn{5}{|c|}{ Augite } & \multirow{3}{*}{$\begin{array}{l}\text { Pig. } \\
\frac{\text { Gm. }}{\text { E37 }}\end{array}$} \\
\hline & \multirow{2}{*}{$\frac{\text { Phc. c. }}{\text { E24 }}$} & \multicolumn{3}{|c|}{$\begin{array}{l}\text { Phc. m. and } \\
\text { microphc. }\end{array}$} & \multicolumn{2}{|c|}{ Phenocryst core } & \multicolumn{2}{|c|}{$\begin{array}{l}\text { Phc. m. and } \\
\text { microphc. }\end{array}$} & \multirow{2}{*}{$\frac{\text { Gm. }}{\text { E28 }}$} & \\
\hline & & E29 & E33 & E35 & E25 & E34 & E32 & E36 & & \\
\hline $\mathrm{SiO}_{2}$ & 51.41 & 52.09 & 51.87 & 52.24 & 50.78 & 50.12 & 49.97 & 50.25 & 50.44 & 51.58 \\
\hline $\mathrm{Al}_{2} \mathrm{O}_{3}$ & 1.61 & 0.87 & 1.20 & 1.79 & 2.14 & 2.49 & 2.12 & 2.97 & 1.90 & 0.96 \\
\hline $\mathrm{TiO}_{2}$ & 0.25 & 0.19 & 0.21 & 0.15 & 0.42 & 0.43 & 0.45 & 0.45 & 0.43 & 0.23 \\
\hline $\mathrm{Cr}_{2} \mathrm{O}_{3}$ & 0.00 & 0.00 & 0.00 & 0.00 & 0.00 & 0.00 & 0.00 & 0.03 & 0.00 & 0.00 \\
\hline $\mathrm{FeO} *^{3}$ & 20.62 & 19.22 & 21.21 & 15.94 & 11.71 & 12.14 & 12.67 & 9.93 & 13.68 & 20.69 \\
\hline $\mathrm{MnO}$ & 0.70 & 0.52 & 0.69 & 0.45 & 0.46 & 0.41 & 0.44 & 0.31 & 0.46 & 0.63 \\
\hline $\mathrm{MgO}$ & 22.07 & 22.96 & 21.36 & 25.66 & 14.72 & 13.95 & 14.22 & 15.43 & 14.89 & 18.94 \\
\hline $\mathrm{CaO}$ & 1.71 & 2.32 & 2.12 & 2.03 & 18.90 & 19.10 & 18.80 & 19.30 & 16.52 & 4.73 \\
\hline $\mathrm{Na}_{2} \mathrm{O}$ & 0.08 & 0.08 & 0.05 & 0.06 & 0.29 & 0.34 & 0.34 & 0.31 & 0.22 & 0.12 \\
\hline Total & 98.45 & 98.25 & 98.71 & 98.32 & 99.42 & 98.98 & 99.01 & 98.98 & 98.54 & 97.88 \\
\hline \multicolumn{11}{|l|}{$O=6.000$} \\
\hline $\mathrm{Si}$ & 1.944 & 1.962 & 1.962 & 1.934 & 1.921 & 1.911 & 1.910 & 1.896 & 1.930 & 1.978 \\
\hline $\mathrm{Al}$ & 0.056 & 0.038 & 0.038 & 0.066 & 0.079 & 0.089 & 0.090 & 0.104 & 0.070 & 0.022 \\
\hline $\mathrm{Al}$ & 0.016 & 0.001 & 0.015 & 0.012 & 0.016 & 0.023 & 0.005 & 0.028 & 0.015 & 0.021 \\
\hline $\mathrm{Ti}$ & 0.007 & 0.005 & 0.006 & 0.004 & 0.012 & 0.012 & 0.013 & 0.013 & 0.012 & 0.007 \\
\hline $\mathrm{Cr}$ & 0.000 & 0.000 & 0.000 & 0.000 & 0.000 & 0.000 & 0.000 & 0.001 & 0.000 & 0.000 \\
\hline $\mathrm{Fe}$ & 0.652 & 0.605 & 0.671 & 0.494 & 0.370 & 0.387 & 0.405 & 0.313 & 0.438 & 0.664 \\
\hline $\mathrm{Mn}$ & 0.022 & 0.017 & 0.022 & 0.014 & 0.015 & 0.013 & 0.014 & 0.010 & 0.015 & 0.020 \\
\hline $\mathrm{Mg}$ & 1.244 & 1.289 & 1.204 & 1.416 & 0.830 & 0.793 & 0.810 & 0.868 & 0.849 & 1.083 \\
\hline $\mathrm{Ca}$ & 0.069 & 0.094 & 0.086 & 0.081 & 0.766 & 0.780 & 0.770 & 0.780 & 0.677 & 0.194 \\
\hline $\mathrm{Na}$ & 0.006 & 0.006 & 0.004 & 0.004 & 0.021 & 0.025 & 0.025 & 0.023 & 0.016 & 0.009 \\
\hline Z & 2.000 & 2.000 & 2.000 & 2.000 & 2.000 & 2.000 & 2.000 & 2.000 & 2.000 & 2.000 \\
\hline WXY & 2.016 & 2.016 & 2.008 & 2.025 & 2.030 & 2.033 & 2.042 & 2.036 & 2.023 & 1.998 \\
\hline \multicolumn{11}{|l|}{ Atomic \% } \\
\hline $\mathrm{Ca}$ & 3.5 & 4.7 & 4.4 & 4.0 & 39.0 & 39.8 & 38.8 & 39.8 & 34.5 & 10.0 \\
\hline $\mathrm{Mg}$ & 63.3 & 64.8 & 61.4 & 71.2 & 42.2 & 40.4 & 40.8 & 44.2 & 43.2 & 55,8 \\
\hline $\mathrm{Fe}$ & 33.2 & 30.5 & 34.2 & 24.8 & 18.8 & 19.7 & 20.4 & 16.0 & 22.3 & 34.2 \\
\hline $\begin{array}{l}\text { Contig. } \\
\text { Anal. No. }\end{array}$ & E25 & & $\mathrm{E} 32$ & E36 & E24 & & E33 & E35 & & \\
\hline
\end{tabular}

Note: See Table 1 for meaning of abbreviations. 
$\mathrm{Mg} / \mathrm{Fe}$ and $\mathrm{Ca} /(\mathrm{Ca}+\mathrm{Mg}+\mathrm{Fe})$ ratios; that is, reverse zoning is observed in the augite crystallization sequence.

Titanomagnetite phenocrysts are subhedral and contain exsolution ilmenite lamellae. The compositions are $\mathrm{Usp}_{26} \mathrm{Mt}_{74}$ to $\mathrm{Usp}_{38} \mathrm{Mt}_{62}$ for the phenocrysts, and $\mathrm{Il}_{77}$ $\mathrm{Ht}_{23}$ (ilmenite-hematite molar ratio) and $\mathrm{Usp}_{14} \mathrm{Mt}_{86}$ for the lamellae and host, respectively.

Orthopyroxene phenocrysts are subhedral to anhedral, relatively fresh, and always surrounded by one of three types of rims: (1) a dark brown alteration product after orthopyroxene, followed in order of abundance by (2) a relatively thick augite rim and (3) a thin pigeonite rim. Reverse zoning is also observed in the Capoor pyroxene crystallization sequence. Chemical compositions of $\mathrm{Ca}$-poor pyroxene vary from hypersthene phenocrysts $\left(\mathrm{Ca}_{3.5} \mathrm{Mg}_{63.5} \mathrm{Fe}_{33}\right)$ with relatively low $\mathrm{Mg} / \mathrm{Fe}$ ratios, through bronzite microphenocrysts $\left(\mathrm{Ca}_{4} \mathrm{Mg}_{71}\right.$ $\mathrm{Fe}_{25}$ ) with high $\mathrm{Mg} / \mathrm{Fe}$ ratios, and through hypersthene microphenocrysts $\left(\mathrm{Ca}_{4.5} \mathrm{Mg}_{61.5} \mathrm{Fe}_{34}\right)$ with relatively low $\mathrm{Mg} / \mathrm{Fe}$ ratios, to groundmass pigeonite crystals $\left(\mathrm{Ca}_{10}\right.$ $\mathrm{Mg}_{56} \mathrm{Fe}_{34}$ ) with low $\mathrm{Mg} / \mathrm{Fe}$ ratios.

Pigeonite is observed in the groundmass and in the rims of the microphenocryst orthopyroxene. Groundmass pigeonite shows small variation in composition between grains.

\section{Bytownite-Hypersthene-Augite-Titanomagnetite Phyric Calc-Alkalic Andesite (Rock F1200)}

The specimen is a clast in the tuff breccia from Hole 451 (Sample 451-59-1, 55-57 cm) (Table 6). Megascopically, the rock is slightly vesicular and gray, with phenocrysts of abundant plagioclase (up to $4 \mathrm{~mm}$ ) and distinct black pyroxene.

Thin-section observations show that the rock consists of phenocrysts and microphenocrysts of plagioclase $(35 \%, 0.5-3 \mathrm{~mm})$, hypersthene $(7 \%, 0.2-1 \mathrm{~mm})$, augite $(5 \%, 0.2-0.8 \mathrm{~mm})$, and titanomagnetite $(3 \%, 0.1-0.3$ $\mathrm{mm}$ ), with a typical hyalopilitic groundmass of plagioclase $(10 \%, 0.005-0.1 \mathrm{~mm})$, augite $(<1 \%, \sim 0.02 \mathrm{~mm})$, titanomagnetite $(<1 \%, \sim 0.01 \mathrm{~mm})$, ilmenite (trace, $\sim 0.01 \mathrm{~mm})$, and devitrified glass $(40 \%)$. Olivine pseudomorphs are not observed.

Plagioclase phenocrysts are subhedral to euhedral, rarely glomerophyric, and show intensive resorption (i.e., honeycombed structure in the core) followed by overgrowth of more sodic plagioclase. Their composition ranges from $\mathrm{An}_{78} \mathrm{Ab}_{22}$ to $\mathrm{An}_{63} \mathrm{Ab}_{37}$ (mainly bytownite) and near $\mathrm{An}_{63} \mathrm{Ab}_{37}$ in the cores of phenocrysts and groundmass plagioclase crystals, respectively. Both are zoned toward $\mathrm{An}_{43} \mathrm{Ab}_{37}$ in their thin rims.

Titanomagnetite phenocrysts are subhedral to euhedral and are free of exsolution. Their compositions are near $\mathrm{Usp}_{25} \mathrm{Mt}_{75}$ and between $\mathrm{Usp}_{31} \mathrm{Mt}_{69}$ and $\mathrm{Usp}_{45}$ $\mathrm{Mt}_{55}$ for phenocrysts and the groundmass titanomagnetite crystals, respectively. Groundmass ilmenite $\left(\mathrm{Il}_{53} \mathrm{Mt}_{47}\right)$ is rarely detected by microprobe.

Hypersthene phenocrysts are euhedral and commonly contain titanomagnetite inclusions. They are partially or wholly replaced by clay minerals in some cases. As shown in Table 6 and Figure 1F, hypersthene phenocrysts are homogeneous $\left(\mathrm{Ca}_{2.5} \mathrm{Mg}_{66.5} \mathrm{Fe}_{31}\right)$ and are rarely

Table 6. The pyroxene analyses of hypersthene-augite phyric calc-alkalic andesite (Rock F1200) from Leg 59, Sample 451-59-1, 55-57 cm.

\begin{tabular}{|c|c|c|c|c|c|c|c|c|c|c|}
\hline \multirow[b]{3}{*}{ Anal. No. } & \multicolumn{5}{|c|}{ Orthopyroxene } & \multicolumn{5}{|c|}{ Augite } \\
\hline & \multicolumn{4}{|c|}{ Phenocryst core } & \multirow{2}{*}{$\frac{\text { Phc. m. }}{\text { F05 }}$} & \multicolumn{2}{|c|}{ Phenocryst core } & \multicolumn{2}{|c|}{ Microphenocryst } & \multirow{2}{*}{$\frac{\text { Gm. }}{\text { F09 }}$} \\
\hline & $\mathrm{F} 02$ & F04 & F08 & F10 & & F03 & F11 & F06 & F07 & \\
\hline $\mathrm{SiO}_{2}$ & 51.19 & 52.86 & 52.81 & 51.96 & 52.29 & 51.27 & 50.79 & 51.65 & 51.55 & 48.24 \\
\hline $\mathrm{Al}_{2} \mathrm{O}_{3}$ & 1.79 & 0.69 & 0.82 & 0.84 & 0.80 & 1.97 & 1.68 & 1.33 & 1.06 & 4.92 \\
\hline $\mathrm{TiO}_{2}$ & 0.21 & 0.11 & 0.12 & 0.13 & 0.14 & 0.40 & 0.31 & 0.23 & 0.17 & 0.77 \\
\hline $\mathrm{Cr}_{2} \mathrm{O}_{3}$ & 0.00 & 0.00 & 0.00 & 0.00 & 0.00 & 0.00 & 0.00 & 0.00 & 0.00 & 0.00 \\
\hline $\mathrm{FeO}^{*}$ & 19.73 & 19.77 & 19.16 & 19.69 & 20.78 & 9.83 & 9.30 & 9.12 & 10.59 & 10.17 \\
\hline $\mathrm{MnO}$ & 0.76 & 0.80 & 0.77 & 0.97 & 1.08 & 0.40 & 0.46 & 0.59 & 0.68 & 0.24 \\
\hline $\mathrm{MgO}$ & 23.16 & 23.68 & 24.13 & 23.29 & 22.18 & 14.25 & 14.05 & 14.68 & 13.54 & 13.67 \\
\hline $\mathrm{CaO}$ & 1.40 & 1.28 & 1.32 & 1.52 & 1.17 & 21.16 & 21.16 & 21.37 & 21.14 & 19.85 \\
\hline $\mathrm{Na}_{2} \mathrm{O}$ & 0.06 & 0.05 & 0.05 & 0.07 & 0.05 & 0.31 & 0.30 & 0.30 & 0.34 & 0.27 \\
\hline Total & 98.30 & 99.24 & 99.18 & 98.47 & 98.49 & 99.59 & 98.05 & 99.27 & 99.07 & 98.13 \\
\hline \multicolumn{11}{|l|}{$\mathrm{O}=6.000$} \\
\hline $\mathrm{Si}$ & 1.931 & 1.970 & 1.964 & 1.957 & 1.957 & 1.930 & 1.940 & 1.947 & 1.960 & 1.844 \\
\hline $\mathrm{Al}$ & 0.069 & 0.030 & 0.036 & 0.037 & 0.025 & 0.070 & 0.060 & 0.053 & 0.040 & 0.156 \\
\hline Al & 0.010 & 0.000 & 0.000 & 0.000 & 0.011 & 0.017 & 0.016 & 0.006 & 0.007 & 0.066 \\
\hline $\mathrm{Ti}$ & 0.006 & 0.003 & 0.003 & 0.004 & 0.004 & 0.011 & 0.009 & 0.007 & 0.005 & 0.022 \\
\hline $\mathrm{Cr}$ & 0.000 & 0.000 & 0.000 & 0.000 & 0.000 & 0.000 & 0.000 & 0.000 & 0.000 & 0.000 \\
\hline $\mathrm{Fe}$ & 0.622 & 0.616 & 0.596 & 0.620 & 0.656 & 0.309 & 0.297 & 0.287 & 0.337 & 0.325 \\
\hline $\mathrm{Mn}$ & 0.024 & 0.025 & 0.024 & 0.031 & 0.035 & 0.013 & 0.015 & 0.019 & 0.022 & 0.008 \\
\hline $\mathrm{Mg}$ & 1.032 & 1.315 & 1.337 & 1.308 & 1.249 & 0.800 & 0.800 & 0.825 & 0.767 & 0.779 \\
\hline $\mathrm{Ca}$ & 0.057 & 0.051 & 0.053 & 0.061 & 0.047 & 0.853 & 0.866 & 0.863 & 0.861 & 0.813 \\
\hline $\mathrm{Na}$ & 0.004 & 0.004 & 0.004 & 0.005 & 0.004 & 0.023 & 0.022 & 0.022 & 0.025 & 0.020 \\
\hline $\mathrm{Z}$ & 2.000 & 2.000 & 2.000 & 1.994 & 2.000 & 2.000 & 2.000 & 2.000 & 2.000 & 2.000 \\
\hline WXY & 2.026 & 2.014 & 2.017 & 2.029 & 2.005 & 2.026 & 2.024 & 2.028 & 2.024 & 2.033 \\
\hline \multicolumn{11}{|l|}{ Atomic $\%$} \\
\hline $\mathrm{Ca}$ & 2.9 & 2.6 & 2.6 & 3.1 & 2.4 & 43.5 & 44.1 & 43.7 & 43.8 & 42.4 \\
\hline $\mathrm{Mg}$ & 65.7 & 66.3 & 67.3 & 65.7 & 64.0 & 40.7 & 40.8 & 41.8 & 39.0 & 40.6 \\
\hline $\mathrm{Fe}$ & 31.4 & 31.1 & 30.0 & 31.2 & 33.6 & 15.8 & 15.1 & 14.6 & 17.1 & 17.0 \\
\hline $\begin{array}{l}\text { Contig. } \\
\text { Anal. No. }\end{array}$ & & F03 & & F11 & & F04 & F10 & & & \\
\hline
\end{tabular}

Note: See Table 1 for meaning of abbreviations. 
rimmed by augite $\left(\mathrm{Ca}_{34} \mathrm{Mg}_{44} \mathrm{Fe}_{22}\right)$. Groundmass hypersthene is not observed.

Augite phenocrysts, commonly containing titanomagnetite inclusions, are euhedral and sometimes resorbed to a round shape. Augite phenocrysts are homogeneous $\left(\mathrm{Ca}_{44} \mathrm{Mg}_{41} \mathrm{Fe}_{15}\right)$ in the core and are rimmed by strongly zoned augite toward $\mathrm{Ca}$-poor augite $\left(\mathrm{Ca}_{32} \mathrm{Mg}_{48} \mathrm{Fe}_{20}\right)$ in some cases. Groundmass augite crystals show zoning from cores $\left(\mathrm{Ca}_{42} \mathrm{Mg}_{41} \mathrm{Fe}_{17}\right)$ to $\mathrm{Ca}$ poor augite rims (about $\mathrm{Ca}_{33} \mathrm{Mg}_{49} \mathrm{Fe}_{18}$ ). Discrete $\mathrm{Ca}$ poor augite is not observed.

\section{PYROXENE GEOTHERMOMETERS}

Detailed data and the method used for these pyroxene geothermometers have been partly reported (Ishii, 1974, 1975; Ishii et al., 1976). These pyroxene geothermometers are briefly summarized in the following material.

\section{Three-Pyroxene Geothermometer (POA-GT)}

Pyroxenes in common mafic magmas are approximated in the three-component system: $\mathrm{CaSiO}_{3}$ $\mathrm{MgSiO}_{3}-\mathrm{FeSiO}_{3}$. In this system, the lower stability limit of pigeonite, or the pigeonite eutectoid reaction (PER) line (Ishii and Takeda, 1974), is the isobaric univariant line on which three phases (pigeonite + orthopyroxene + augite) coexist. A practical application of the PER line to geothermometry was initiated by Ishii (1974). Based on the compositions of such pyroxenes in two lavas in Japan of known eruption temperature as well as on Brown's experimental data (Brown, 1968), the PER line was approximated by

$$
T=1270-480 X_{\mathrm{Fe}}
$$

where $T$ is temperature in ${ }^{\circ} \mathrm{C}$ and $X_{\mathrm{Fe}}$ is atomic ratio $\mathrm{Fe} /(\mathrm{Mg}+\mathrm{Fe})$ (Ishii, 1975).

The PER line can be used as a three-pyroxene geothermometer (i.e., if the composition of the pigeonite that crystallized on or close to the PER line is known, its crystallization temperature can be determined by using this equation). In some basic lavas and intrusives, pyroxene assemblages change during crystallization from orthopyroxene + augite to pigeonite + augite. In this pyroxene crystallization sequence, the most magnesian pigeonite crystallizes close to the PER line. For example, the crystallization temperature $1118^{\circ} \mathrm{C}$ was deduced for the most magnesian pigeonite with $X_{\mathrm{Fe}}=0.317$ in Rock A814.

\section{Orthopyroxene-Augite Geothermometer (OA-GT)}

Not many experimental low-pressure data on the enstatite-diopside two-phase region are available at present. We calibrated Wood and Banno's formula (1973), estimated from high-pressure data, by employing compositions of four orthopyroxene-augite pairs in three-pyroxene rocks collected from Funagata (Aoki, 1960; Ishii, 1974), Hakone (Kuno, 1936; Ishii, 1974), Ashio (Kuno, 1969; Ishii, 1974), and Weiselberg (Nakamura and Kushiro, 1970b). These data are shown in Figure 2 and Table 7 . Crystallization temperatures

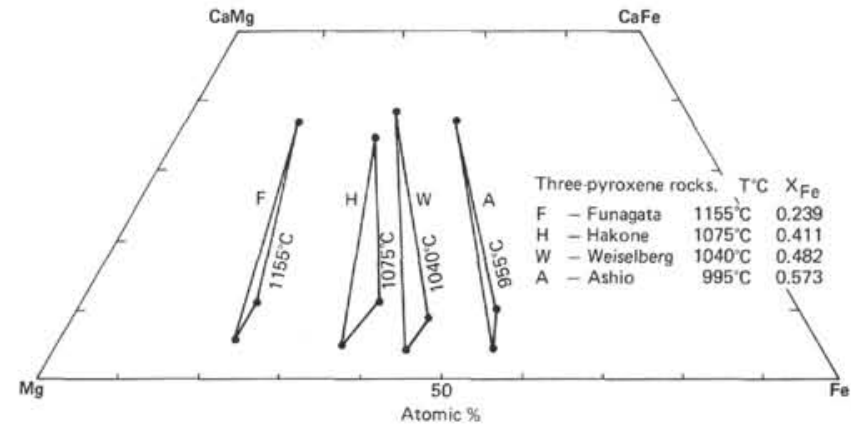

Figure 2. Ca-Mg-Fe plot of coexisting three-pyroxene phenocrysts.

estimated from the compositions of the coexisting pigeonites (by the PER line just cited) are also shown in Table 7. According to Wood and Banno, the crystallization temperature (in terms of $X_{\mathrm{Fe}}$ of orthopyroxene) is given as:

$$
\begin{aligned}
T=A /[ & \ln \left(\alpha_{\mathrm{Mg}_{2} \mathrm{Si}_{2} \mathrm{O}_{6}}^{\mathrm{Aug}} / \alpha_{\mathrm{Mg}_{2} \mathrm{Si}_{2} \mathrm{O}_{6}}^{\mathrm{Opx}}\right) \\
& \left.-B-C X_{\mathrm{Fe}}-D X_{\mathrm{Fe}}^{2}\right]-273
\end{aligned}
$$

where $\alpha$ is component activity. Accepting the $A(-10202)$ and $B(4.6)$ values of Wood and Banno, we obtain $C(7.10)$ and $D(-6.02)$ by employing the least-squares method on the four-pyroxene pairs data (Table 7).

\section{Pigeonite-Augite Geothermometer (PA-GT)}

Assuming that equation (2) will still be valid even if orthopyroxene is replaced by pigeonite, the $A(-6232)$ and $B(2.96)$ terms at $X_{\mathrm{Fe}}=0$ were estimated from the pigeonite-augite solvus at low pressure (Boyd and Schairer, 1964; Kushiro, 1972; Yang, 1973). The $C(1.141)$ and $D(0.68)$ values were obtained by employing the compositions of pigeonite and augite (Table 7) from the four sets of the three-pyroxene assemblages and by employing their estimated temperatures.

These three kinds of pyroxene geothermometers can be used to estimate the crystallization temperature of pyroxenes in the lavas using a Fortran computer program coded by Miyamoto (Ishii et al., 1976).

\section{ESTIMATION OF CRYSTALLIZATION TEMPERATURES OF PYROXENES}

The compositions of Ca-poor and Ca-rich pyroxene pairs crystallized at equilibrium in each rock have been obtained by detailed microprobe analyses. Using these data we estimated the equilibrium crystallization temperatures of pyroxenes with the previously mentioned pyroxene geothermometers.

In the anorthite-bronzite-augite-phyric basalt (C860), bronzite phenocrysts are partially replaced by clay minerals along the margins. Augite and bronzite phenocrysts are in contact with each other, as if augite crystals were molded into a single large bronzite crystal, as shown in Figure 3. Many microprobe-scan traverses across these crystals for $\mathrm{Ca}, \mathrm{Mg}$, and $\mathrm{Fe}$ have revealed that each crystal is very homogeneous and that minor chemical zoning is observed only in augite in the narrow 
Table 7. The pyroxene analyses of three pyroxene rocks from Funagata, ${ }^{a}$ Hakone ${ }^{b}$ Weiselberg, ${ }^{c}$ and Ashio. ${ }^{d}$

\begin{tabular}{|c|c|c|c|c|c|c|c|c|c|c|c|c|}
\hline \multirow{2}{*}{$\begin{array}{c}\begin{array}{c}\text { Samples } \\
\text { and Temp. }\end{array} \\
\text { Anal. No. }\end{array}$} & \multicolumn{3}{|c|}{ Funagata $\left(1115^{\circ} \mathrm{C}\right)^{e}$} & \multicolumn{3}{|c|}{ Hakone $\left(1073^{\circ} \mathrm{C}\right)$} & \multicolumn{3}{|c|}{ Weiselberg $\left(1039^{\circ} \mathrm{C}\right)$} & \multicolumn{3}{|c|}{ Ashio $\left(995^{\circ} \mathrm{C}\right)$} \\
\hline & $\begin{array}{c}\text { Opx }{ }^{f} \\
1\end{array}$ & $\begin{array}{c}\text { Pig. } \\
2\end{array}$ & $\underset{3}{\text { Aug. }}$ & $\underset{4}{\text { Opx. }}$ & $\begin{array}{c}\text { Pig. } \\
5\end{array}$ & $\underset{6}{\text { Aug. }}$ & Opx. & $\begin{array}{l}\text { Pig. } \\
8\end{array}$ & Aug. & $\begin{array}{c}\text { Opx. } \\
10\end{array}$ & $\begin{array}{c}\text { Pig. } \\
11\end{array}$ & $\underset{12}{\text { Aug. }}$ \\
\hline $\mathrm{SiO}_{2}$ & 53.8 & 52.9 & 52.1 & 51.1 & 51.0 & 49.8 & 51.6 & 51.1 & 50.3 & 48.8 & 49.2 & 48.9 \\
\hline $\mathrm{Al}_{2} \mathrm{O}_{3}$ & 1.56 & 1.53 & 2.33 & 1.70 & 1.54 & 2.78 & 0.67 & 0.62 & 1.43 & 1.58 & 1.00 & 2.34 \\
\hline $\mathrm{TiO}_{2}$ & 0.17 & 0.13 & 0.28 & 0.27 & 0.41 & 0.61 & 0.33 & 0.29 & 0.68 & 0.32 & 0.29 & 0.48 \\
\hline $\mathrm{FeO}^{*}$ & 14.5 & 13.9 & 8.97 & 22.4 & 22.4 & 14.9 & 27.0 & 26.9 & 15.1 & 32.2 & 30.1 & 19.6 \\
\hline $\mathrm{MnO}$ & 0.34 & 0.34 & 0.28 & 0.48 & 0.60 & 0.37 & 0.56 & 0.66 & 0.38 & 0.67 & 0.71 & 0.44 \\
\hline $\mathrm{MgO}$ & 27.2 & 24.8 & 17.7 & 21.4 & 18.0 & 14.1 & 18.3 & 16.2 & 12.4 & 13.6 & 12.6 & 9.93 \\
\hline $\mathrm{CaO}$ & 2.54 & 5.72 & 18.2 & 2.23 & 5.29 & 16.5 & 1.86 & 4.07 & 18.1 & 2.05 & 4.59 & 17.0 \\
\hline $\mathrm{Na}_{2} \mathrm{O}$ & 0.03 & 0.08 & 0.15 & 0.04 & 0.11 & 0.35 & n.d. & n.d. & n.d. & 0.00 & 0.15 & 0.24 \\
\hline Total & 100.1 & 99.4 & 100.0 & 99.6 & 99.3 & 99.4 & 100.3 & 99.8 & 98.4 & 99.2 & 98.6 & 98.9 \\
\hline \multicolumn{13}{|l|}{$\mathrm{O}=6.000$} \\
\hline $\mathrm{Si}$ & 1.941 & 1.938 & 1.924 & 1.927 & 1.947 & 1.900 & 1.969 & 1.974 & 1.947 & 1.941 & 1.965 & 1.922 \\
\hline $\mathrm{Al}$ & 0.059 & 0.062 & 0.076 & 0.073 & 0.053 & 0.100 & 0.030 & 0.026 & 0.053 & 0.059 & 0.035 & 0.078 \\
\hline $\mathrm{Al}$ & 0.007 & 0.004 & 0.025 & 0.003 & 0.016 & 0.025 & 0.000 & 0.003 & 0.013 & 0.015 & 0.012 & 0.030 \\
\hline $\mathrm{Ti}$ & 0.005 & 0.004 & 0.008 & 0.008 & 0.012 & 0.018 & 0.009 & 0.008 & 0.020 & 0.010 & 0.009 & 0.014 \\
\hline $\mathrm{Fe}$ & 0.437 & 0.426 & 0.277 & 0.706 & 0.715 & 0.475 & 0.862 & 0.869 & 0.489 & 1.071 & 1.005 & 0.644 \\
\hline $\mathrm{Mn}$ & 0.010 & 0.011 & 0.009 & 0.015 & 0.019 & 0.012 & 0.018 & 0.022 & 0.012 & 0.023 & 0.024 & 0.015 \\
\hline $\mathrm{Mg}$ & 1.463 & 1.354 & 0.974 & 1.203 & 1.024 & 0.802 & 1.041 & 0.933 & 0.716 & 0.806 & 0.750 & 0.582 \\
\hline $\mathrm{Ca}$ & 0.098 & 0.224 & 0.720 & 0.090 & 0.216 & 0.675 & 0.076 & 0.168 & 0.751 & 0.087 & 0.196 & 0.716 \\
\hline $\mathrm{Na}$ & 0.002 & 0.006 & 0.011 & 0.003 & 0.008 & 0.026 & - & - & - & 0.000 & 0.012 & 0.018 \\
\hline Z & 2.000 & 2.000 & 2.000 & 2.000 & 2.000 & 2.000 & 2.000 & 2.000 & 2.000 & 2.000 & 2.000 & 2.000 \\
\hline WXY & 2.022 & 2.028 & 2.023 & 2.029 & 2.011 & 2.033 & 2.006 & 2.003 & 2.000 & 2.012 & 2.008 & 2.019 \\
\hline \multicolumn{13}{|l|}{ Atomic $\%$} \\
\hline $\mathrm{Ca}$ & 4.9 & 11.2 & 36.5 & 4.5 & 11.1 & 34.6 & 3.8 & 8.5 & 38.4 & 4.4 & 10.1 & 36.9 \\
\hline $\mathrm{Mg}$ & 73.2 & 67.6 & 49.4 & 60.2 & 52.4 & 41.1 & 52.6 & 47.3 & 36.6 & 41.0 & 38.4 & 30.0 \\
\hline $\mathrm{Fe}$ & 21.9 & 21.2 & 14.1 & 35.3 & 36.6 & 24.4 & 43.5 & 44.1 & 25.0 & 54.5 & 51.5 & 33.2 \\
\hline
\end{tabular}

Note: $\mathrm{FeO}^{*}=$ total $\mathrm{Fe}$ as $\mathrm{FeO}$.

a From Aoki, 1960; Ishii, 1974.

b From Kuno, 1936; Ishii, 1974.

c From Nakamura and Kushiro, 1970 b.

d From Kuno, 1969; Ishii, 1974.

e Crystallization temperatures estimated by the three-pyroxene geothermometer (see text).

Abbreviations: Opx. = orthopyroxene; Pig. = pigeonite; Aug. = augite.

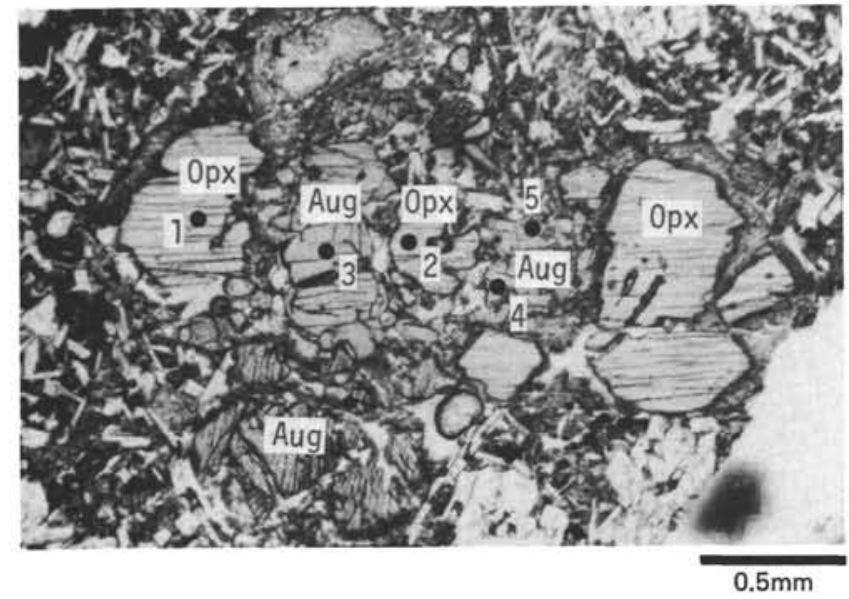

Figure 3. Photomicrograph of analyzed orthopyroxenes and augites (represented by the black circles).

margin in contact with the groundmass. The chemical compositions of the uniform portions of each pyroxene are given in Table 3 and Figure $1 \mathrm{C}$, and the regions analyzed are marked by the black circles in Figure 3 . This textural and chemical evidence suggests that the two pyroxenes were crystallized from magma in equilibrium.

Compositions determined with the contiguous crystals of bronzite and augite are connected by straight lines (Fig. 1C). The crystallization temperatures were deduced with the orthopyroxene-augite geothermometer using each pyroxene pair according to equa- tion (2). The estimated temperatures from three pyroxene pairs-Opx C01-Aug C03, Opx C02-Aug C03, and Opx C02-Aug C04 in Table 3-are $1129^{\circ} \mathrm{C}, 1134^{\circ} \mathrm{C}$, and $1131^{\circ} \mathrm{C}$, respectively, and average $1131^{\circ} \mathrm{C}$. The crystallization temperature $1131^{\circ} \mathrm{C}$ was obtained for the core of the mosi magnesian orthopyroxene phenocryst (with $X_{\mathrm{Fe}}=0.262$ ). The temperatures deduced by a detailed investigation of pyroxene pairs contained in each rock are shown in Table 8, and plotted in Figure 4, (where the $X_{\mathrm{Fe}}$ value is of the most magnesian orthopyroxene-phenocryst core).

Hakone Volcano in Central Japan is a typical islandarc type stratovolcano, and its geology and petrology have been investigated in detail by Kuno (1950). Detailed microprobe data on pyroxenes in the tholeitic

Table 8. Estimated temperature of magma by pyroxene geothermometers.

\begin{tabular}{llcccccc}
\hline & Rock & $\begin{array}{c}\mathrm{SiO}_{2}{ }^{\mathrm{a}} \\
(\text { wt. \%) }\end{array}$ & $\begin{array}{c}\mathrm{SI}^{\mathrm{a}} \\
\text { value }\end{array}$ & $\begin{array}{c}X_{\mathrm{Fe}}{ }^{\mathrm{b}} \text { of } \\
\text { opx. phc. }\end{array}$ & $\begin{array}{c}\text { Phc. } \\
\text { stage }^{\mathrm{d}} \\
\left({ }^{\circ} \mathrm{C}\right)\end{array}$ & $\begin{array}{c}\text { Gm. } \\
\text { stage } \\
\left({ }^{\circ} \mathrm{C}\right)\end{array}$ & $\begin{array}{c}\text { Differ- } \\
\text { ence } \\
\left({ }^{\circ} \mathrm{C}\right)\end{array}$ \\
\hline Site 448 & $\mathrm{A} 814$ & 53.63 & 18.97 & 0.254 & 1100 & 1120 & +20 \\
& $\mathrm{~B} 815$ & 48.27 & 23.78 & 0.243 & 1075 & 1095 & +20 \\
& C860 & 49.20 & 24.78 & 0.262 & 1130 & - & - \\
& Dite 451 & 49.99 & 24.72 & 0.278 & 1055 & 1115 & +60 \\
& E1130 & 50.6 & 33.74 & 0.344 & 1055 & 1090 & +35 \\
& F1200 & 57.2 & 20.35 & 0.319 & 970 & - & - \\
\hline
\end{tabular}

a See Table 9 for values.

b $X_{\mathrm{Fe}}$ is mole fraction of $\mathrm{Fe}$ in orthopyroxene (see text).

c Abbreviations: $\mathrm{Opx} .=$ orthopyroxene; $\mathrm{Phc} .=$ phenocryst $\mathrm{Gm}$. = groundmass.

d Temperature of magma in the magma chamber.

e Temperature of magma in the effusive stage. 


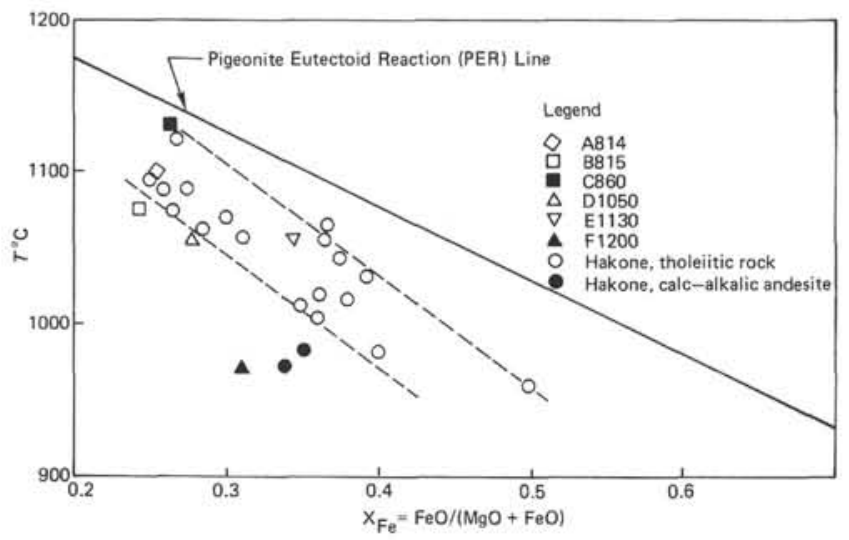

Figure 4. Crystallization temperatures of orthopyroxene phenocrysts and $X_{\mathrm{Fe}}$ values.

and calc-alkalic rocks from Hakone Volcano have been reported in part (Ishii, 1974, 1976, 1978). These data are also shown in Figure 4.

The following features are remarkable: (1) the crystallization temperature of orthopyroxene phenocryst cores of Rock F1200 is at least $80^{\circ} \mathrm{C}$ lower than that of the other samples from the Philippine Sea; (2) the tholeiitic rocks from the Hakone Volcano have certain ranges of crystallization temperatures, and the lowest of the Hakone tholeiites is still higher than those with similar $X_{\mathrm{Fe}}$ values in the calc-alkalic rocks from the Hakone Volcano; and (3) Rock F1200 is plotted near the positions of calc-alkalic rocks, whereas the other five samples fall in the area of the tholeiitic rocks of Hakone Volcano.

The core of phenocrysts in each sample started to crystallize at equilibrium in the magma chamber. Its composition and crystallization temperature may also reflect fractional crystallization of the magma in the magma chamber. It may therefore be reasonable to assume that the temperatures estimated earlier correspond to the temperature in the magma chamber. In the following discussion, the temperatures of the magma will be represented by those temperatures of phenocrysts listed in Table 8. It is notable that the estimated temperatures of the groundmass stage of crystallization are higher than those of the phenocryst stage.

\section{CHEMISTRY OF ROCKS AND TEMPERATURE OF MAGMA}

Major elements contained in rocks and glass used in this study have been analyzed by three methods: XRF analyses by the Birmingham University group (Mattey et al., this volume) and by Ishii; wet chemical analyses (gravimetric, flame photometric, and calorimetric) by Haramura; and electron probe microanalyses (EPMA) by Ishii. The analytic results and their CIPW norms are shown in Table 9. By wet chemical method, H. Haramura analyzed 8 samples, including 3 rocks in Table 9 collected from the Palau-Kyushu and West Mariana ridges (see Appendix). The $\mathrm{Fe}_{2} \mathrm{O}_{3} / \mathrm{FeO}$ ratio of these 8 samples averages 1.06. Contents of $\mathrm{Fe}_{2} \mathrm{O}_{3}$ and $\mathrm{FeO}$ in

Table 9. The major-element analyses of rocks and glasses from Leg 59, Holes 448, 448A and 451.

\begin{tabular}{|c|c|c|c|c|c|c|c|c|c|c|}
\hline \multirow{2}{*}{$\begin{array}{c}\text { Rock } \\
\text { Sample }\end{array}$} & \multirow{2}{*}{$\begin{array}{c}\frac{\mathrm{A} 814}{448-59-1} \\
61 \mathrm{~cm}\end{array}$} & \multirow{2}{*}{$\begin{array}{c}\frac{B 815}{448-59-1,} \\
115 \mathrm{~cm}\end{array}$} & \multicolumn{2}{|c|}{$\mathrm{C} 860$} & \multicolumn{4}{|c|}{ D1050 } & \multirow{2}{*}{$\begin{array}{c}\text { E1130 } \\
\begin{array}{c}451-46-1 \\
24 \mathrm{~cm}\end{array}\end{array}$} & \multirow{2}{*}{$\begin{array}{c}\frac{F 1200}{451-59-1} \\
54 \mathrm{~cm}\end{array}$} \\
\hline & & & $\begin{array}{c}448 \mathrm{~A}-62-1 \\
70 \mathrm{~cm}\end{array}$ & $\begin{array}{c}448 \mathrm{~A}-62-1, \\
70 \mathrm{~cm}\end{array}$ & $\begin{array}{c}451-38-1 \\
134 \mathrm{~cm}\end{array}$ & $\begin{array}{c}451-38-1 \\
137 \mathrm{~cm}\end{array}$ & $\begin{array}{c}451-38-1 \\
134 \mathrm{~cm}\end{array}$ & $\begin{array}{c}451-38-1 \\
134 \mathrm{~cm}\end{array}$ & & \\
\hline Anal. No. & 1 & 2 & 3 & 4 & 5 & 6 & 7 & $8^{c}$ & 9 & 10 \\
\hline $\mathrm{SiO}_{2}$ & 53.63 & 48.27 & 49.20 & 49.71 & 49.99 & 50.30 & 49.59 & 53.76 & 50.60 & 57.20 \\
\hline $\mathrm{TiO}_{2}$ & 1.22 & 0.97 & 0.93 & 0.92 & 0.68 & 0.70 & 0.63 & 1.33 & 0.77 & 0.65 \\
\hline $\mathrm{Al}_{2} \mathrm{O}_{3}$ & 12.37 & 17.18 & 19.45 & 18.67 & 19.76 & 19.00 & 19.03 & 12.30 & 15.80 & 17.70 \\
\hline $\mathrm{Fe}_{2} \mathrm{O}_{3} \mathrm{a}$ & 6.70 & 5.95 & 4.69 & 4.96 & 4.45 & 4.88 & 4.57 & 7.31 & 5.27 & 3.40 \\
\hline $\mathrm{FeO}$ & 6.70 & 6.11 & 5.26 & 4.96 & 4.92 & 4.88 & 4.57 & 7.31 & 5.27 & 3.40 \\
\hline $\mathrm{MnO}$ & 0.17 & 0.20 & 0.15 & 0.15 & 0.17 & 0.18 & 0.16 & 0.30 & 0.17 & 0.15 \\
\hline $\mathrm{MgO}$ & 3.69 & 4.69 & 4.01 & 3.86 & 3.87 & 4.31 & 3.65 & 3.12 & 6.70 & 3.03 \\
\hline $\mathrm{CaO}$ & 8.18 & 9.16 & 10.67 & 10.84 & 10.52 & 10.83 & 10.45 & 7.19 & 9.58 & 8.60 \\
\hline $\mathrm{Na}_{2} \mathrm{O}$ & 2.59 & 2.78 & 2.48 & (1.87) & 2.16 & 2.16 & (1.65) & 2.93 & 2.52 & 3.27 \\
\hline $\mathrm{K}_{2} \mathrm{O}$ & 0.44 & 0.79 & 0.21 & 0.21 & 0.70 & 0.72 & 0.71 & 1.51 & 0.62 & 2.13 \\
\hline $\mathrm{P}_{2} \mathrm{O}_{5}$ & n.d. & 0.15 & 0.12 & 0.20 & 0.13 & 0.06 & 0.20 & n.d. & 0.23 & 0.14 \\
\hline $\mathrm{H}_{2} \mathrm{O}^{+}$ & n.d. & 1.33 & 1.13 & n.d. & 1.83 & n.d. & n.d. & n.d. & n.d. & n.d. \\
\hline $\mathrm{H}_{2} \mathrm{O}^{-}$ & n.d. & 2.11 & 1.92 & n.d. & 0.92 & n.d. & n.d. & n.d. & n.d. & n.d. \\
\hline Total & 95.71 & 99.69 & 100.22 & 96.35 & 100.10 & 98.02 & 95.21 & 97.06 & 97.53 & 99.67 \\
\hline $\mathrm{Ni}$ (ppm) & $(150)^{b}$ & 37 & 24 & n.d. & 21 & 3 & n.d. & $(0)$ & 5 & 2 \\
\hline $\mathrm{Cr}(\mathrm{ppm})$ & $(0)$ & 20 & 16 & n.d. & 11 & 12 & n.d. & (0) & 23 & 11 \\
\hline \multicolumn{11}{|l|}{ CIPW Norm } \\
\hline Q & 16.53 & 3.38 & 5.92 & 10.56 & 6.90 & 6.66 & 10.50 & 12.91 & 5.32 & 9.43 \\
\hline Or & 2.72 & 4.85 & 1.28 & 1.29 & 4.25 & 4.34 & 4.41 & 9.19 & 3.76 & 12.63 \\
\hline $\mathrm{Ab}$ & 22.90 & 24.44 & 21.59 & 16.42 & 18.77 & 18.65 & 14.66 & 25.54 & 21.86 & 27.76 \\
\hline An & 21.76 & 33.31 & 42.52 & 43.52 & 43.30 & 40.83 & 44.55 & 16.43 & 30.73 & 27.42 \\
\hline Wo & 8.62 & 5.38 & 4.65 & 4.57 & 3.94 & 5.67 & 3.56 & 8.48 & 6.87 & 6.04 \\
\hline En & 9.60 & 12.13 & 10.28 & 9.98 & 9.90 & 10.95 & 9.55 & 8.00 & 17.11 & 7.57 \\
\hline Fs & 5.28 & 5.27 & 4.66 & 3.91 & 4.67 & 4.19 & 4.07 & 5.92 & 4.48 & 2.65 \\
\hline $\mathrm{Mt}$ & 10.15 & 8.96 & 7.00 & 7.46 & 6.63 & 7.22 & 6.96 & 10.92 & 7.83 & 4.95 \\
\hline II & 2.42 & 1.91 & 1.82 & 1.81 & 1.33 & 1.36 & 1.26 & 2.60 & 1.50 & 1.24 \\
\hline Ap & 0.00 & 0.36 & 0.29 & 0.48 & 0.31 & 0.14 & 0.49 & 0.00 & 0.55 & 0.33 \\
\hline $\mathrm{SI}^{\mathrm{d}}$ & 18.97 & 23.78 & 24.78 & 25.12 & 24.72 & 26.18 & 24.84 & 14.55 & 33.75 & 20.35 \\
\hline Analyst ${ }^{d}$ & T.I. & H.H. & H.H. & T.I. & H.H. & J.T. \& N.M. & T.I. & T.I. & J.T. \& N.M. & J.T. \& N.M. \\
\hline Method & EPMA & Wet C. & Wet C. & XRF & Wet $\mathrm{C}$. & XRF & XRF & EPMA & XRF & XRF \\
\hline
\end{tabular}

${ }^{a} \mathrm{Fe}_{2} \mathrm{O}_{3} / \mathrm{FeO}=1.0$ for EPMA and XRF data (see text).

$b$ Degree of reliability is relatively low.

c Glass inclusion in the plagioclase phenocryst of Rock D1050.

Abbreviations: $\mathrm{SI}=$ solidification index; Wet $\mathrm{C}$. = wet chemical analysis; T.I. = T. Ishii; H.H. = H. Haramura; J.T. \& N.M. = J. Tarney \& N. Marsh (Mattey et al., this volume). 
other samples analyzed by XRF and EPMA are only calculated on the assumption that the $\mathrm{Fe}_{2} \mathrm{O}_{3} / \mathrm{FeO}$ ratio is 1.0. Because of the common occurrence of alteration products, migration of some elements is expected during alteration in the seafloor environment. Nevertheless, it is remarkable that many rocks are quartz normative and have high $\mathrm{Al}_{2} \mathrm{O}_{3}$ contents and low $\mathrm{Na}_{2} \mathrm{O} / \mathrm{K}_{2} \mathrm{O}$ ratios.

Results of analyses including glass plotted in Figure 5 are used to classify the volcanic rocks according to their chemical composition. In Figure $5 \mathrm{~A}$, the $\mathrm{SiO}_{2}$ $\left(\mathrm{Na}_{2} \mathrm{O}+\mathrm{K}_{2} \mathrm{O}\right)$ diagram (Kuno, 1965), and in the $\mathrm{Al}_{2} \mathrm{O}_{3}-\left(\mathrm{Na}_{2} \mathrm{O}+\mathrm{K}_{2} \mathrm{O}\right)-\mathrm{SiO}_{2}$ (Kuno, 1960) diagram (Fig. $5 \mathrm{~B}$ ), all rocks plotted exist in the areas of high alumina basalt and the tholeiite. In Figure $5 \mathrm{C}$, the $\mathrm{MgO}-\mathrm{FeO}-$ $\left(\mathrm{Na}_{2} \mathrm{O}+\mathrm{K}_{2} \mathrm{O}\right)$ diagram, the data fall on the tholeiitic/ calc-alkalic boundary (estimated by Kuno [1954] in the Izu-Hakone region) and into the calc-alkalic field. On the other hand, in both $\mathrm{SiO}_{2}-\mathrm{FeO} * / \mathrm{MgO}$ (Fig. 5D) and $\mathrm{FeO}^{*}-\mathrm{FeO}^{*} / \mathrm{MgO}$ (Fig. 5E) plots (Miyashiro, 1974), Rock F1200 lies in the calc-alkalic field, but all the others fall in the tholeiitic field.

Minor-element chemistry determined by XRF (Mattey et al., this volume) is also available for the samples from the Palau-Kyushu and West Mariana ridges. These selected data are shown in Table 10 with compiled chemical values of calc-alkalic, island-arc tholeiitic, and abyssal tholeiitic series (Jakeš and Gill, 1970). It is clear that none of the samples from the Palau-Kyushu and West Mariana ridges are abyssal tholeiites. According to the criteria of Jakeš and Gill, data of $\mathrm{Rb}$ and $\mathrm{Ba}$ contents, as well as $\mathrm{Rb} / \mathrm{Sr}$ and $\mathrm{Na}_{2} \mathrm{O} / \mathrm{K}_{2} \mathrm{O}$ ratios (Table 10), strongly suggest that F1200 is of calc-alkalic affinity, whereas D1050, E1130, and the others from the PalauKyushu and West Mariana ridges are of island-arc tholeiitic affinities. However, Sr contents are very high in the calc-alkalic and tholeiitic rocks from the West Mariana Ridge.

Temperatures of magma deduced in the previous section (Table 8) are plotted with respect to major-element analyses (Fig. 6) and to the solidification index (SI) of bulk rock; the solidification index is $100 \times \mathrm{Mg} /(\mathrm{MgO}$ $+\mathrm{FeO}^{*}+\mathrm{Na}_{2} \mathrm{O}+\mathrm{K}_{2} \mathrm{O}$ ) (Kuno, 1954) and can be used as an indicator of degree of differentiation of magma (Fig. 7). The data of previously studied igneous rocks are also shown in Figure 7.

The following remarkable features are shown in Figure 7 ; (1) the temperatures of magmas from the Palau-Kyushu Ridge are higher than those from the West Mariana Ridge, with similar SI values, (2) tholeiitic magmas from Hakone Volcano have certain temperature ranges, the highest one of which is still lower than those of some tholeiitic magmas from the other area; (3) Rock F1200 is very close to the calc-alkalic magma of the Hakone Volcano; and (4) the other five samples from the Palau-Kyushu and West Mariana ridges are included in the high- and low-temperature regions of the tholeiitic magma. It is expected that Rock F1200 is of calc-alkalic affinity.

As shown in Figures 6 and 7, magmas with a similar chemical composition of nonvolatile components have a very wide temperature range. According to the data, it is difficult to judge which components have significant efects on the temperature of magmas. Oxygen pressure does not significantly lower their temperature (Aramaki and Katsura, 1973). Differences in volatile content, particularly water, appear to be the controlling factor in determining these temperature differences. It is suggested that water content in the high-temperature magma is lower than that in the low-temperature one. Temperature differences (Fig. 7) suggest that water content of the Palau-Kyushu Ridge magma was lower than that of the West Mariana Ridge magma and that water content of the F1200 magma was as high as the calc-alkalic magma of Hakone Volcano.

\section{MAGNETIC PROPERTY AND PALEOENVIRONMENT}

Changes in saturation magnetization $(J s)$ with temperature $(T)$ were studied with five of the samples; the glass sample (A814) was excluded. The method of measurement is the same as that described by Kobayashi et al. (1979).

Two types of samples can be distinguished by their thermomagnetic behavior: a thermally reversible type and an irreversible type. Samples from the West Mariana Ridge (Fig. 8A) are thermally reversible and those from the Palau-Kyushu Ridge (Fig. 8B) irreversible. Their Curie temperatures are estimated to be $440^{\circ} \mathrm{C}$ (B815), $280^{\circ} \mathrm{C}(\mathrm{C} 860), 350^{\circ} \mathrm{C}$ (D1050), $560^{\circ} \mathrm{C}$ (E1130), and $505^{\circ} \mathrm{C}$ (F1200) by heating experiments.

As previously mentioned, the exsolution lamellae of ilmenite in titanomagnetite can only be observed by microscope and microprobe in Rock E1130.The occurrence and magnetic properties of titanomagnetite in the volcanic clasts of the West Mariana Ridge can be interpreted to indicate that the clasts have suffered from high-temperature oxidation. It is plausible that these volcanic rocks were erupted and cooled in a subaerial environment.

The thermomagnetic behavior of Rocks B815, taken from the interior of a massive lava, and C860, from interior of a massive dike from the Palau-Kyushu Ridge, indicates that the former has undergone intensive lowtemperature oxidation, whereas the latter has undergone relatively weak low-temperature oxidation. It is expected that the degree of oxidation depends on the geological environments in which magmas were settled. It may be reasonable to assume that magma of $\mathrm{B} 815$ was erupted and cooled on the seafloor and was intensively oxidized by seawater, whereas magma of C860 intruded into the previously settled pyroclastic sediment in the seafloor so that the effect of seawater was relatively weak. Magnetic properties seem to be a useful tool with which to investigate the geologic paleoenvironment in which igneous activity occured.

\section{DISCUSSION AND CONCLUSION}

The volcanic sequences at Sites 448 and 451 were formed by basaltic igneous activities that differ significantly from typical oceanic igneous activity forming Layer 2 of the oceanic crust. Abundance of pyroclastic rocks, high vesicularity of extrusive units, and wide 


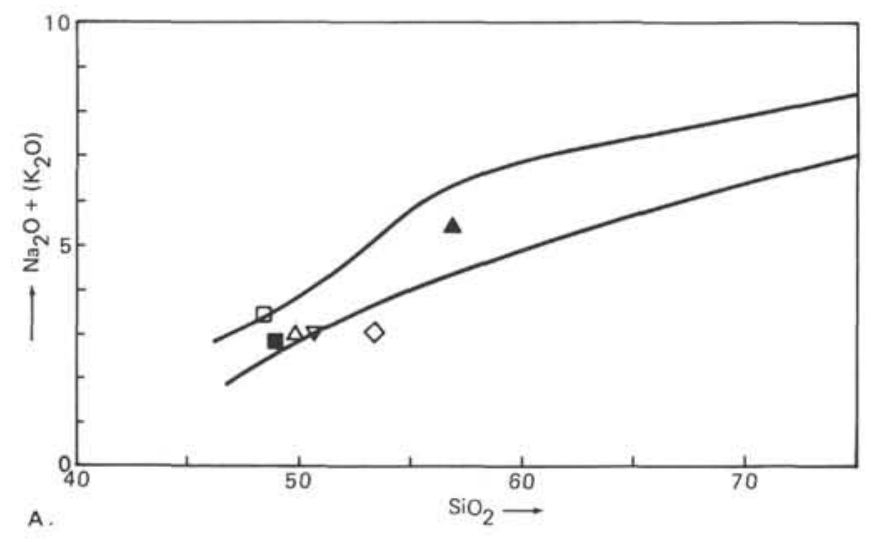

A.
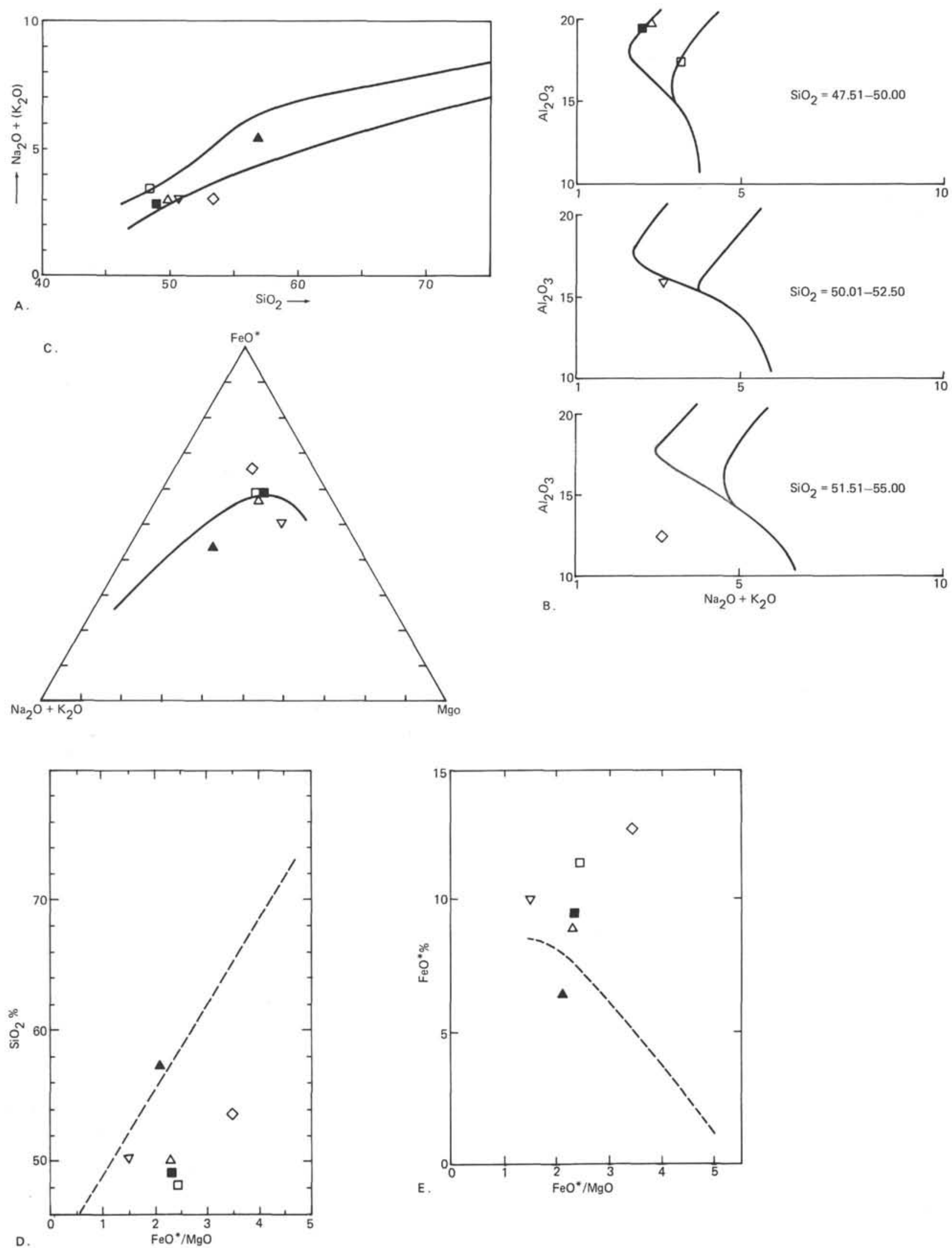

Figure 5. Various diagrams to classify volcanic rocks according to their major chemistry. A. $\mathrm{SiO}_{2}-\left(\mathrm{Na}_{2} \mathrm{O}+\mathrm{K}_{2} \mathrm{O}\right)$ diagram B. $\mathrm{Al}_{2} \mathrm{O}_{3}-\left(\mathrm{Na}_{2} \mathrm{O}+\mathrm{K}_{2} \mathrm{O}\right)-\mathrm{SiO}_{2}$ diagram. C. $\mathrm{MgO}-\mathrm{FeO}^{*}-\left(\mathrm{Na}_{2} \mathrm{O}+\mathrm{K}_{2} \mathrm{O}\right)$ diagram. D. $\mathrm{SiO}_{2} \mathrm{O}-\mathrm{FeO} * / \mathrm{MgO}$ diagram. E. FeO*$\mathrm{FeO}^{*} / \mathrm{MgO}$ diagram. (Symbols are the same as in Fig. 4. $\mathrm{FeO}^{*}=$ total $\mathrm{Fe}$ as $\mathrm{FeO}$.) 
Table 10. Selected minor-element analyses.

\begin{tabular}{|c|c|c|c|c|c|c|c|c|}
\hline & \multicolumn{5}{|c|}{ (Mattey et al., this volume) } & \multicolumn{3}{|c|}{ (Jakeš and Gill, 1970) } \\
\hline & \multicolumn{3}{|c|}{ Site 451, West Mariana Ridge } & \multirow{2}{*}{$\begin{array}{l}\text { Site } 448 \\
\left(\text { rangea }^{\mathrm{a}}\right)\end{array}$} & \multirow{2}{*}{$\begin{array}{l}\text { Site } 451 \\
\left(\text { rangeb) }^{b}\right.\end{array}$} & \multirow{2}{*}{$\begin{array}{l}\text { Calc- } \\
\text { Alkalic } \\
\text { Series }\end{array}$} & \multirow{2}{*}{$\begin{array}{c}\text { Island-Arc } \\
\text { Tholeiitic } \\
\text { Series }\end{array}$} & \multirow{2}{*}{$\begin{array}{c}\text { Abyssal } \\
\text { Tholeiiti } \\
\text { Series }\end{array}$} \\
\hline & D1050 & E1130 & F1200 & & & & & \\
\hline \multicolumn{9}{|l|}{$\mathrm{ppm}$} \\
\hline $\mathrm{Ni}$ & 3 & 5 & 2 & $1-30$ & 3-13 & 18 & $0-30$ & $30-200$ \\
\hline $\mathrm{Cr}_{\mathrm{r}}-\mathrm{r}$ & 12 & 23 & 11 & $11-69$ & $7-23$ & 56 & $0-50$ & $200-400$ \\
\hline $\mathrm{Rb}$ & 11 & 8 & 43 & $0-21$ & $2-11$ & 30 & $3-10$ & $0.2-5.0$ \\
\hline $\mathrm{Sr}$ & 493 & 539 & 520 & $137-212$ & $482-621$ & 380 & $100-200$ & $70-150$ \\
\hline $\mathrm{Ba}$ & 176 & 186 & 446 & $22-99$ & $114-186$ & 270 & $50-150$ & $6-30$ \\
\hline \multicolumn{9}{|l|}{ Ratio } \\
\hline $\mathrm{K} / \mathrm{Rb}$ & 541 & 639 & 411 & $604-2681$ & $541-1136$ & $400-500$ & 1000 & 1000 \\
\hline $\mathrm{Rb} / \mathrm{Sr}$ & 0.022 & 0.015 & 0.083 & $0.006-0.146$ & $0.004-0.022$ & $0.05-0.10$ & $0.01-0.05$ & 0.02 \\
\hline $\mathrm{Na}_{2} \mathrm{O} / \mathrm{K}_{2} \mathrm{O}$ & 3.09 & 4.06 & 1.54 & $1.27-24.80$ & $1.54-9.68$ & $2-3$ & 4-6 & $10-15$ \\
\hline
\end{tabular}

${ }^{\mathrm{a}}$ Excluding analysis of Sample $448 \mathrm{~A}-36-4,130 \mathrm{~cm}$.

b Excluding analyses of Rock F1200 and Sample 451-102,CC, $11 \mathrm{~cm}$.

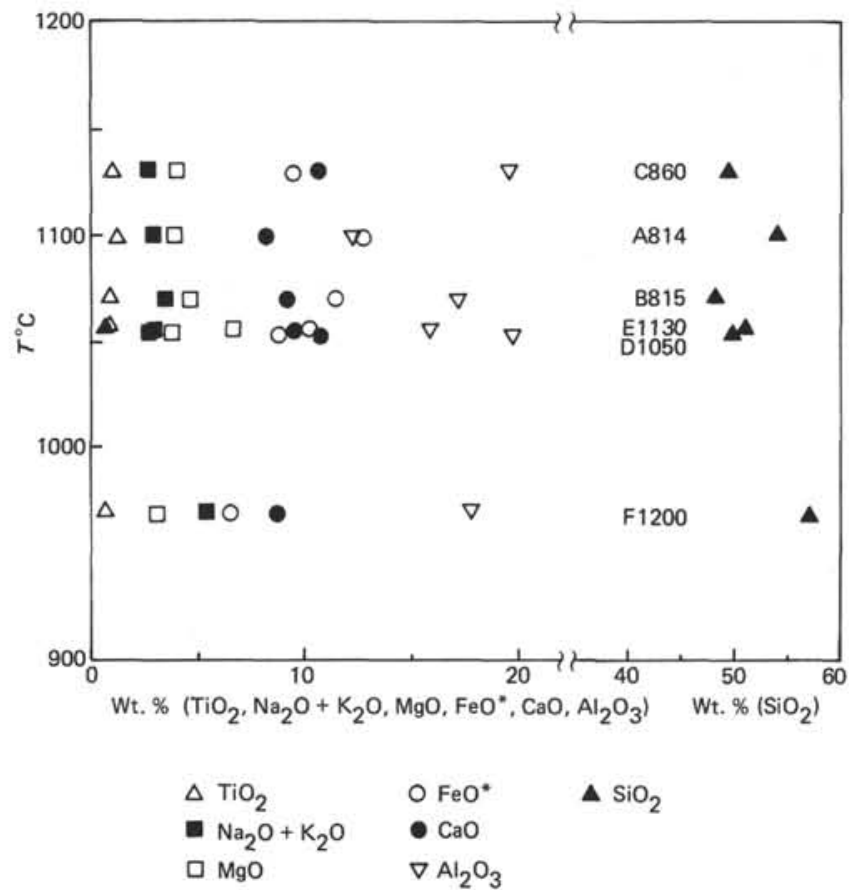

Figure 6. Temperatures of magmas and major-element analyses.

distribution of orthopyroxene phenocrysts suggest that the volcanic rocks are of island-arc affinity.

This conclusion is supported by major and minor geochemical data: abundance of normative quartz, high content of $\mathrm{Al}_{2} \mathrm{O}_{3}, \mathrm{Rb}, \mathrm{Sr}$, and $\mathrm{Ba}$, low content of $\mathrm{Ni}$ and $\mathrm{Cr}$, and low ratio of $\mathrm{Na}_{2} \mathrm{O} / \mathrm{K}_{2} \mathrm{O}$ are obvious chemical evidences of the volcanic activities of the island-arc tholeiite and/or calc-alkalic affinities.

Occurrence of groundmass orthopyroxene is a mineralogically reliable criterion to distinguish the calcalkalic rock from tholeiite (Kuno, 1950, 1954). Unfortunately, it is difficult to apply this criterion to altered rocks and glassy samples with low crystallinity of groundmass. In this chapter, groundmass orthopyroxene has not been found with the microscope or microprobe.

Occurrences of titanomagnetite phenocrysts and intensively resolved plagioclase phenocrysts with honey-

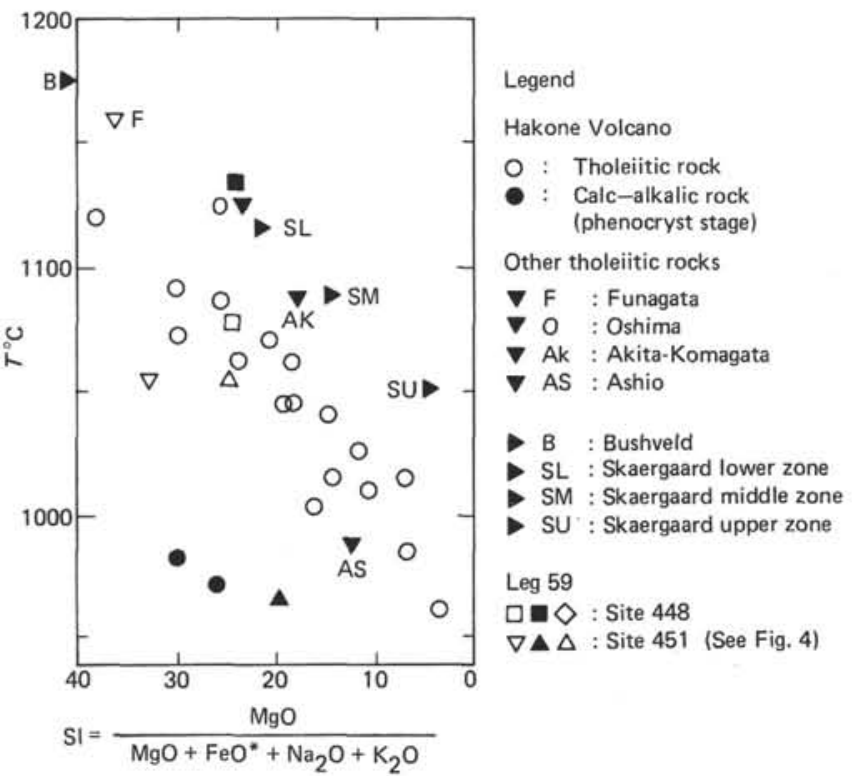

Figure 7. Temperatures of magmas and solidification indexes (SI) (see Ishii, 1978)

combed structure, followed by overgrowth of more sodic plagioclase, may be other criteria for identifying calc-alkalic rocks but are not sufficiently reliable.

On the bases of the geochemical criteria-high $\mathrm{Rb}$ and $\mathrm{Ba}$ contents, high $\mathrm{Rb} / \mathrm{Sr}$ ratio, and low $\mathrm{Na}_{2} \mathrm{O} / \mathrm{K}_{2} \mathrm{O}$ ratio-one sample (F1200) can be distinguished as a calc-alkalic rock from the other rocks, which are islandarc tholeiites (Table 10).

Furthermore, Rock F1200 can be independently identified as a calc-alkalic rock by new criteria: the comparative studies of crystallization temperature of orthopyroxene phenocrysts and its $X_{\mathrm{Fe}}$ value (Fig. 4) as well as of the temperature of magma (obtained by pyroxene geothermometers) and its solidification index (Fig. 7).

It may be reasonable to state that the present rocks are classified into the following three groups: (1) hightemperature island-arc tholeiite (A814, B815, and C860), (2) low-temperature island-arc tholeiite (D1050 and E1130) and (3) calc-alkalic andesite (F1200). The 

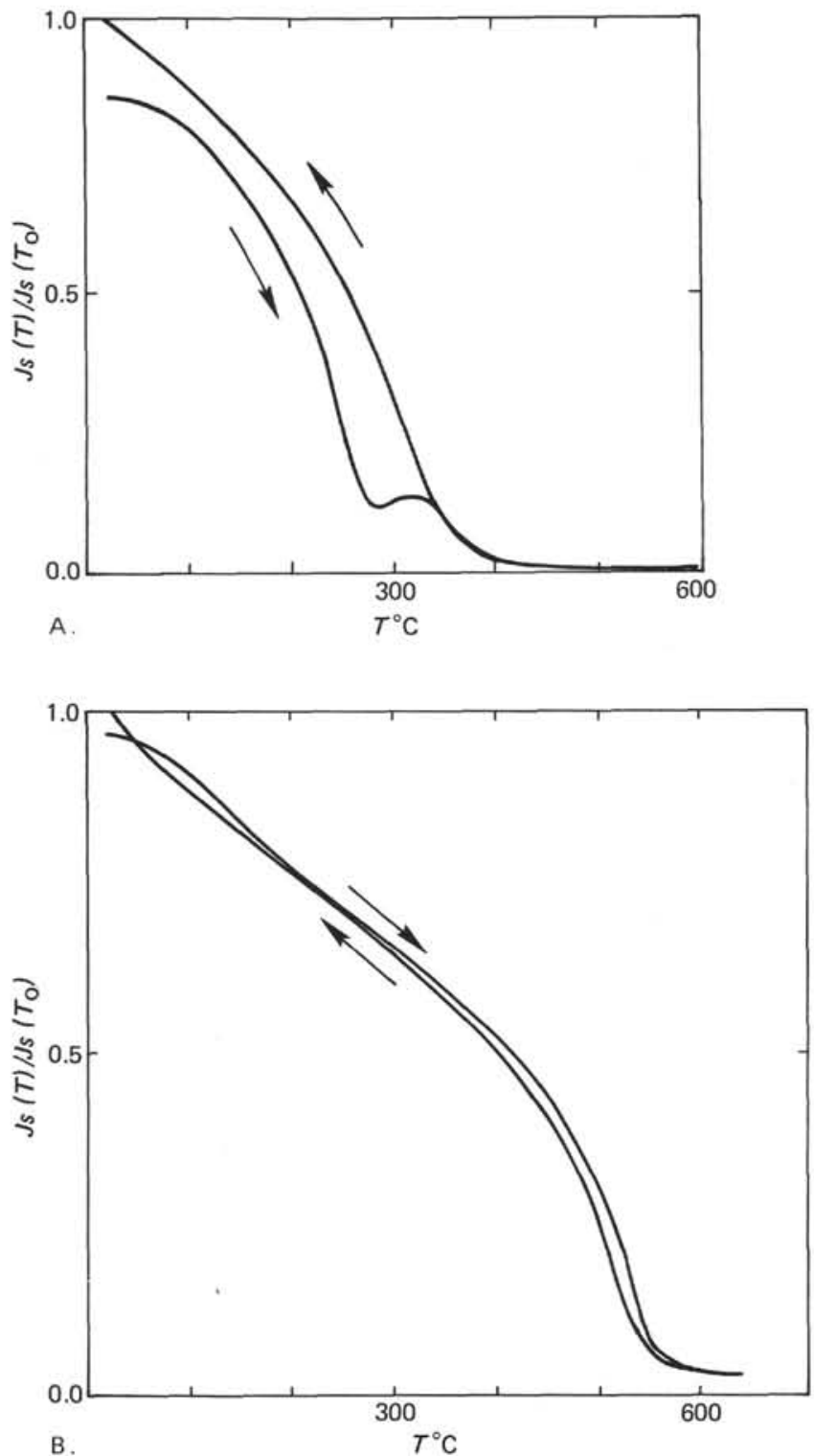

Figure 8. A. Thermomagnetism curves, thermally irreversible type (C860); B. Thermomagnetism curves, thermally reversible type (E1130).

water content of magma increases in this order. A problem then arises as to the cause of varied water contents in the island-arc magma. Further investigation of the crustal structure and the evolutionary history of the two remnant arcs may solve the problem.

\section{ACKNOWLEDGMENTS}

The author is very grateful to the late Professor Hisashi Kuno for his consultation on the pyroxene problem, to Professor K. Kobayashi (University of Tokyo) for his critical reading of the manuscript, and to Mr. H. Haramura (University of Tokyo) for his wet chemical analyses. Thanks are also extended to Professors I. Kushiro and $\mathrm{H}$. Takeda, and to Mrs. T. Furuta, K. Fujioka, and H. Tokuyama (University of Tokyo) for their discussions and encouragements during the research and to Miss $\mathrm{K}$. Tabata for her help in preparation of the manuscript.

\section{REFERENCES}

Aoki, K., 1960. Early stage basalts from the Nasu volcanic zone. $J$. Japan Assoc. Mineral. Petrol. Econ. Geol., 45:54-65.

Aramaki, S., and Katsura, T., 1973. Petrology and liquidus temperature of the magma of the 1970 eruption of Akita-Komagatake volcano, northeastern Japan. J. Japan Assoc. Mineral. Petrol. Econ. Geol., 68:101-124.

Boyd, F. R., and Schairer, J. F., 1964. The system $\mathrm{MgSiO}_{3}-$ $\mathrm{CaMgSi}_{2} \mathrm{O}_{6}$. J. Petrol., 5:275-309.

Brown, G. M., 1968. Experimental studies on inversion relations in natural pigeonitic pyroxenes. Carnegie Inst. Washington yearbook, 66:347-353.

Hilde, T. W. C., Uyeda, S., and Kroenke, L., 1977. Evolution of the western Pacific and its margins. Tectonophysics, 30:145-165.

Ishii, T., 1974. Pyroxene geothermometry and its application to the petrological study of the Hakone Volcano [Ph.D. dissert.]. University of Tokyo.

1975. The relations between temperature and composition of pigeonite in some lavas and their application to geothermometry. Mineral. J., 8:48-57.

1976. Crystallization temperature and composition of pyroxenes from tholeiitic magmas, Hakone Volcano, Japan. Geol. Soc. Am. 1976 Annual Meetings, 8:936-937. (Abstract)

1978. Temperature and water content of tholeitic magmas from Hakone Volcano and Bushveld intrusion. Intern. Geophys. Conf. "Western Pacific" and "Magma Genesis"' (Tokyo), pp. 256-257. (Abstract)

Ishii, T., Miyamoto, M., and Takeda, H., 1976. Pyroxene geothermometry and crystallization, subsolidus equilibration temperatures of lunar and achondritic pyroxenes. Lunar Science VII: Houston (Lunar Science Institute), pp. 408-410.

Ishii, T., and Takeda, H., 1974. Inversion, decomposition and exsolution phenomena of terrestrial and extraterrestrial pigeonites. Mem. Geol. Soc. Japan, 11:19-36.

Ishii, T., Takeda, H., and Yanai, K., 1979. Pyroxene geothermometry applied to a three-pyroxene achondrite from Allan Hills, Antarctica and ordinary chondrites. Mineral. J., 9:460-481.

Jakeš, P., and Gill, J., 1970. Rare earth elements and the arc tholeiitic series. Earth Planet. Sci. Lett., 9:17-28.

Karig, D. E., 1975. Basin genesis in the Philippine Sea. In Karig, D. E., Ingle, J. C., Jr., et al., Init. Repts. DSDP, 31: Washington (U.S. Govt. Printing Office), 857-879.

Kobayashi, K., Steiner, M., Faller, A., et al., 1979. Magnetic mineralogy of basalts from Leg 49. In Luyendyk, B. P., Cann, J. R., et al., Init. Repts. DSDP, 49: Washington (U.S. Govt. Printing Office), 793-805.

Kuno, H., 1936. Petrological notes on some pyroxene-andesites from Hakone volcano, with special reference to some types with pigeonite phenocrysts. Japan J. Geol. Geogr., 13:107-140. , 1950. Petrology of Hakone Volcano and the adjacent areas, Japan. Bull. Geol. Soc. Am., 61:957-1020. 1954. Volcanoes and Volcanic Rocks: Tokyo (Iwanami). 1960. High-alumina basalt. J. Petrol., 1:121-145. 1965. Fractionation trends of basalt magmas in lava flows. J. Petrol., 6:302-321.

1969. Pigeonite-bearing andesite and associated dacite from Ashio, Japan. Am. J. Sci., 267:257-268.

Kushiro, I., 1972. Determination of liquidus relations in synthetic silicate systems with electron probe analysis: the system forsteritediopside-silica at 1 atmosphere. Am. Mineral., 57:1260-1271.

Miyashiro, A., 1974. Volcanic rock series in island arcs and active continental margins. Am. J. Sci., 274:321-355.

Nakamura, Y., and Kushiro, I., 1970a. Compositional relations of coexisting orthopyroxene, pigeonite, and augite in a tholeiitic andesite from Hakone volcano. Contrib. Mineral. Petrol., 26:265-275. 1970b. Equilibrium relations of hypersthene, pigeonite, and augite in crystallizing magmas: microprobe study of a pigeonite andesite from Weiselberg, Germany. Am. Mineral., 55:1999-2015.

Uyeda, S., and Ben-Avraham, Z., 1972. Origin and development of the Philippine Sea. Nature, 240:176-178. 
Wood, B. J., and Banno, S., 1973. Garnet-orthopyroxene and orthopyroxene-clinopyroxene relationships in simple and complex systems. Contrib. Mineral. Petrol., 42:109-124.

Yang, H. Y., 1973. Crystallization of iron-free pigeonite in the system anorthite-diopside-enstatite-silica at atmospheric pressure. Am. J. Sci., 273:488-497.

\section{APPENDIX}

Data on Major-Element Compositions of DSDP Leg 59 Tholeiitic Basalt, Calc-Alkalic Andesite, and Glass Obtained by Wet Chemical Analysis, XRF, and EPMA Methods

Teruaki Ishii, Ocean Research Institute, University of Tokyo, Minamidai, Nakano-ku, Tokyo 164, Japan and

Hiroshi Haramura, Geological Institute, Faculty of Science, University of Tokyo, Hongo, Tokyo 113, Japan

During the DSDP Leg 59 cruise, various igneous rocks (lava, intrusive rocks, volcaniclastic breccias and tuffs) were obtained from Sites 447 through 451 , along the South Philippine Sea transect; these include oceanic igneous rocks from the West Philippine Basin (Site 447) and the Parece Vela Basin (Sites 449 and 450), and island-arc igneous rocks from the Palau-Kyushu Ridge (Site 448) and West Mariana Ridge (Site 451). Major-element analyses of rocks and glasses as well as microprobe analyses of some minerals will be presented in this Appendix.
The major elements contained in some rocks and glasses obtained during Leg 59 have been analyzed by three methods: wet chemical analyses by Haramura, XRF analyses, and electron microanalyses (EPMA) by Ishii (preceding chapter). The analytic results and their CIPW norms are shown in Tables 1 through 8 and Figure 1 (the oxide [wt. \%]-solidification index [SI] diagram). The microprobe analyses reported in the preceding chapter include groundmass compositions of rocks from the West Mariana Ridge and roughly estimated bulk compositions of hornblende gabbro from the Palau-Kyushu Ridge. To obtain reliable composition with polished thin sections, these sections were moved rapidly over a wide area under the electron beam during analysis.

The hornblende gabbro consists of green hornblende, augite, plagioclase, and opaques. Plagioclase-olivine-phyric basalts from the lowermost part of Hole 447A contain plagioclase aggregates and Alrich pyroxene and plagioclase xenocrysts. Microprobe analyses of those particular minerals in the above rocks are presented in Tables 9 and 10 and plotted in Figures 2 and 3 .

\section{ACKNOWLEDGMENTS}

The author is grateful to Mr. K. Fujioka and Dr. R. Matsumoto for their help on the XRF analyses, to Dr. M. Nomura, Mr. A. Uchiyama, and Mr. K. Kutsukake for the computer programs they contributed to the study, and to Miss S. Washida for her help in preparation of the manuscript. I thank Professor K. Kobayashi for his encouragements during the research.

Table 1. The major-element analyses obtained by wet chemical analysis of the rocks from Leg 59, Holes $447 \mathrm{~A}, 449$, and $450 .^{\mathrm{a}}$

\begin{tabular}{|c|c|c|c|c|c|c|c|c|c|}
\hline \multirow[b]{2}{*}{ Anal. No. } & \multicolumn{5}{|c|}{ West Philippine Sea Basin } & \multicolumn{4}{|c|}{ Parece Vela Basin } \\
\hline & 1 & 2 & 3 & 4 & sb & 6 & 7 & 8 & 9 \\
\hline Sample & $\begin{array}{c}447 \mathrm{~A}-19-3 \\
85 \mathrm{~cm}\end{array}$ & $\begin{array}{c}447 \mathrm{~A}-23-1 \\
39 \mathrm{~cm}\end{array}$ & $\begin{array}{c}447 \mathrm{~A}-24-2 \\
99 \mathrm{~cm}\end{array}$ & $\begin{array}{c}447 \mathrm{~A}-27-1 \\
21 \mathrm{~cm}\end{array}$ & $\begin{array}{c}447 \mathrm{~A}-36-5 \\
9 \mathrm{~cm}\end{array}$ & $\begin{array}{c}449-15-2 \\
1 \mathrm{~cm}\end{array}$ & $\begin{array}{c}449-17-2 \\
98 \mathrm{~cm}\end{array}$ & $\begin{array}{c}450-36-2 \\
125 \mathrm{~cm}\end{array}$ & $\begin{array}{c}450-36-3 \\
134 \mathrm{~cm}\end{array}$ \\
\hline $\mathrm{SiO}_{2}$ & 46.80 & 49.60 & 46.80 & 46.23 & 41.25 & 46.12 & 46.32 & 46.50 & 47.09 \\
\hline $\mathrm{TiO}_{2}$ & 1.14 & 1.07 & 0.83 & 0.84 & 0.79 & 0.92 & 1.05 & 1.42 & 1.34 \\
\hline $\mathrm{Al}_{2} \mathrm{O}_{3}$ & 16.32 & 15.11 & 17.29 & 18.86 & 16.48 & 16.81 & 18.06 & 17.50 & 16.31 \\
\hline $\mathrm{Fe}_{2} \mathrm{O}_{3}$ & 6.95 & 2.43 & 2.40 & 5.20 & 5.51 & 6.43 & 6.63 & 7.23 & 6.00 \\
\hline $\mathrm{FeO}$ & 4.19 & 7.19 & 5.97 & 3.22 & 3.07 & 3.37 & 3.96 & 3.55 & 4.37 \\
\hline $\mathrm{MnO}$ & 0.15 & 0.17 & 0.14 & 0.15 & 0.13 & 0.19 & 0.15 & 0.17 & 0.18 \\
\hline $\mathrm{MgO}$ & 6.06 & 8.47 & 9.58 & 7.17 & 4.53 & 6.12 & 4.84 & 4.84 & 6.08 \\
\hline $\mathrm{CaO}$ & 11.70 & 11.79 & 11.87 & 11.76 & 16.60 & 12.03 & 11.71 & 11.35 & 12.14 \\
\hline $\mathrm{Na}_{2} \mathrm{O}$ & 2.40 & 2.13 & 2.28 & 2.31 & 2.05 & 2.57 & 2.79 & 2.87 & 2.66 \\
\hline $\mathrm{K}_{2} \mathrm{O}$ & 0.61 & 0.05 & 0.06 & 0.41 & 1.02 & 0.37 & 0.35 & 0.81 & 0.32 \\
\hline $\mathrm{P}_{2} \mathrm{O}_{5}$ & 0.11 & 0.07 & 0.05 & 0.04 & 0.14 & 0.15 & 0.27 & 0.25 & 0.20 \\
\hline $\mathrm{H}_{2} \mathrm{O}^{+}$ & 2.30 & 1.36 & 2.40 & 3.16 & 0.94 & 2.60 & 1.62 & 2.30 & 1.98 \\
\hline $\mathrm{H}_{2} \mathrm{O}-$ & 1.37 & 0.80 & 0.70 & 0.92 & 1.50 & 2.59 & 2.03 & 1.32 & 1.41 \\
\hline $\mathrm{CO}_{2}$ & - & - & - & - & 6.1 & - & - & - & - \\
\hline Total & 100.10 & 100.24 & 100.37 & 100.27 & 100.11 & 100.27 & 99.78 & 100.11 & 100.08 \\
\hline \multicolumn{10}{|c|}{ CIPW Norm } \\
\hline Q & 2.11 & 0.63 & 0.0 & 0.0 & 0.0 & 0.82 & 1.57 & 0.70 & 1.28 \\
\hline Or & 3.74 & 0.30 & 0.36 & 2.52 & 6.58 & 2.30 & 2.15 & 4.96 & 1.96 \\
\hline $\mathrm{Ab}$ & 21.06 & 18.37 & 19.83 & 20.32 & 4.65 & 22.87 & 24.56 & 25.17 & 23.28 \\
\hline An & 33.14 & 32.14 & 37.80 & 41.46 & 35.77 & 34.96 & 37.16 & 33.66 & 32.70 \\
\hline $\mathrm{Ne}$ & 0.0 & 0.0 & 0.0 & 0.0 & 7.74 & 0.0 & 0.0 & 0.0 & 0.0 \\
\hline Wo & 10.98 & 11.29 & 9.35 & 7.90 & 14.28 & 11.18 & 8.95 & 9.61 & 11.79 \\
\hline En & 9.33 & 7.22 & 6.46 & 6.68 & 12.32 & 9.66 & 7.57 & 8.30 & 9.61 \\
\hline Fs & 0.22 & 3.33 & 2.13 & 0.19 & 0.02 & 0.0 & 0.21 & 0.0 & 0.76 \\
\hline En & 6.32 & 14.29 & 3.95 & 9.00 & 0.0 & 6.37 & 4.97 & 4.19 & 6.05 \\
\hline Fs & 0.15 & 6.60 & 1.30 & 0.26 & 0.0 & 0.0 & 0.14 & 0.0 & 0.47 \\
\hline Fo & 0.0 & 0.0 & 9.89 & 2.02 & 0.0 & 0.0 & 0.0 & 0.0 & 0.0 \\
\hline $\mathrm{Fa}$ & 0.0 & 0.0 & 3.59 & 0.06 & 0.0 & 0.0 & 0.0 & 0.0 & 0.0 \\
\hline Mt & 10.45 & 3.59 & 3.58 & 7.84 & 8.72 & 9.27 & 10.00 & 8.17 & 9.00 \\
\hline II & 2.25 & 2.07 & 1.62 & 1.66 & 1.64 & 1.84 & 2.07 & 2.80 & 2.63 \\
\hline Ap & 0.26 & 0.17 & 0.12 & 0.10 & 0.35 & 0.37 & 0.65 & 0.60 & 0.48 \\
\hline $\mathrm{Ni}$ (ppm) & 93 & 74 & 130 & 125 & 96 & 102 & 80 & 62 & 84 \\
\hline $\mathrm{Cr}$ (ppm) & 256 & 226 & 275 & 260 & 336 & 208 & 212 & 260 & 268 \\
\hline
\end{tabular}

Analyst: H. Haramura.

b Intensively altered. 
Table 2 . The major-element analyses obtained by wet chemical analysis of rocks from Leg 59 , Holes $448,448 \mathrm{~A}$, and $451 .^{\mathrm{a}}$

\begin{tabular}{|c|c|c|c|c|c|c|c|c|}
\hline \multirow[b]{2}{*}{ Anal. No. } & \multicolumn{5}{|c|}{ Palau-Kyushu Ridge } & \multicolumn{3}{|c|}{ West Mariana Ridge } \\
\hline & 1 & 2 & 3 & 4 & 5 & 6 & 7 & 8 \\
\hline Sample & $\begin{array}{c}448-59-1 \\
115 \mathrm{~cm}\end{array}$ & $\begin{array}{c}448 \mathrm{~A}-16-3 \\
50 \mathrm{~cm}\end{array}$ & $\begin{array}{c}448 \mathrm{~A}-50-2 \\
2 \mathrm{~cm}\end{array}$ & $\begin{array}{c}448 \mathrm{~A}-62-1 \\
5 \mathrm{~cm}\end{array}$ & $\begin{array}{c}448 \mathrm{~A}-62-1 \\
70 \mathrm{~cm}\end{array}$ & $\begin{array}{c}451-38-1 \\
134 \mathrm{~cm}\end{array}$ & $\begin{array}{c}451-59-1 \\
60 \mathrm{~cm}\end{array}$ & $\begin{array}{c}451-69-2 \\
85 \mathrm{~cm}\end{array}$ \\
\hline $\mathrm{SiO}_{2}$ & 48.27 & 48.31 & 49.21 & 49.54 & 49.20 & 49.99 & 55.01 & 57.34 \\
\hline $\mathrm{TiO}_{2}$ & 0.97 & 1.06 & 1.29 & 1.13 & 0.93 & 0.68 & 0.72 & 0.62 \\
\hline $\mathrm{Al}_{2} \overline{\mathrm{O}}_{3}$ & 17.18 & 17.46 & 14.07 & 18.38 & 19.45 & 19.76 & 18.78 & 17.70 \\
\hline $\mathrm{Fe}_{2} \mathrm{O}_{3}$ & 5.95 & 5.69 & 6.97 & 5.69 & 4.69 & 4.45 & 4.17 & 2.48 \\
\hline $\mathrm{FeO}$ & 6.11 & 6.45 & 6.71 & 4.78 & 5.26 & 4.92 & 2.67 & 4.22 \\
\hline $\mathrm{MnO}$ & 0.20 & 0.22 & 0.20 & 0.25 & 0.15 & 0.17 & 0.16 & 0.17 \\
\hline $\mathrm{MgO}$ & 4.69 & 3.89 & 5.38 & 3.88 & 4.01 & 3.87 & 1.77 & 2.05 \\
\hline $\mathrm{CaO}$ & 9.16 & 10.01 & 8.18 & 9.41 & 10.67 & 10.52 & 9.26 & 7.12 \\
\hline $\mathrm{Na}_{2} \mathrm{O}$ & 2.78 & 2.81 & 2.42 & 2.91 & 2.48 & 2.16 & 3.26 & 3.93 \\
\hline $\mathrm{K}_{2} \mathrm{O}$ & 0.79 & 0.71 & 0.23 & 0.42 & 0.21 & 0.70 & 2.55 & 1.23 \\
\hline $\mathrm{P}_{2} \mathrm{O}_{5}$ & 0.15 & 0.21 & 0.17 & 0.20 & 0.12 & 0.13 & 0.28 & 0.32 \\
\hline $\mathrm{H}_{2} \mathrm{O}+$ & 1.33 & 1.62 & 1.79 & 1.24 & 1.13 & 1.83 & 1.50 & 2.33 \\
\hline $\mathrm{H}_{2} \mathrm{O}^{-}$ & 2.11 & 1.93 & 3.55 & 2.39 & 1.92 & 0.92 & 0.12 & 0.59 \\
\hline Total & 99.69 & 100.37 & 100.17 & 100.22 & 100.22 & 100.10 & 100.25 & 100.10 \\
\hline \multicolumn{9}{|c|}{ CIPW Norm } \\
\hline Q & 3.38 & 3.38 & 10.26 & 6.69 & 5.92 & 6.90 & 7.70 & 11.77 \\
\hline Or & 4.85 & 4.33 & 1.43 & 2.57 & 1.28 & 4.25 & 15.28 & 7.48 \\
\hline $\mathrm{Ab}$ & 24.44 & 24.56 & 21.59 & 25.49 & 21.59 & 18.77 & 27.97 & 34.22 \\
\hline An & 33.31 & 34.01 & 28.31 & 37.11 & 42.52 & 43.30 & 29.48 & 27.81 \\
\hline $\mathrm{Ne}$ & 0.0 & 0.0 & 0.0 & 0.0 & 0.0 & 0.0 & 0.0 & 0.0 \\
\hline Wo & 5.38 & 6.62 & 5.56 & 4.12 & 4.65 & 3.94 & 5.68 & 2.67 \\
\hline En & 3.49 & 3.93 & 3.77 & 2.94 & 2.99 & 2.50 & 4.47 & 1.32 \\
\hline Fs & 1.52 & 2.35 & 1.35 & 0.81 & 1.36 & 1.18 & 0.57 & 1.29 \\
\hline En & 8.64 & 6.07 & 10.36 & 7.06 & 7.29 & 7.40 & 0.0 & 3.93 \\
\hline Fs & 3.75 & 3.64 & 3.71 & 1.96 & 3.30 & 3.49 & 0.0 & 3.84 \\
\hline Fo & 0.0 & 0.0 & 0.0 & 0.0 & 0.0 & 0.0 & 0.0 & 0.0 \\
\hline $\mathrm{Fa}$ & 0.0 & 0.0 & 0.0 & 0.0 & 0.0 & 0.0 & 0.0 & 0.0 \\
\hline Mt & 8.96 & 8.52 & 10.66 & 8.54 & 7.00 & 6.63 & 6.13 & 3.70 \\
\hline II & 1.91 & 2.08 & 2.58 & 2.22 & 1.82 & 1.33 & 1.39 & 1.21 \\
\hline Ap & 0.36 & 0.50 & 0.42 & 0.48 & 0.29 & 0.31 & 0.66 & 0.76 \\
\hline $\mathrm{Ni}$ (ppm) & 37 & 24 & 24 & 24 & 24 & 21 & 16 & 8 \\
\hline $\mathrm{Cr}(\mathrm{ppm})$ & 20 & 16 & 18 & 12 & 16 & 11 & 8 & 5 \\
\hline
\end{tabular}

a Analyst: H. Haruyama.

Table 3. The major-element analyses obtained by XRF method of the rocks from Leg 59 , Holes 449 and $450 .^{\mathrm{a}}$

\begin{tabular}{|c|c|c|c|c|c|c|}
\hline \multirow[b]{3}{*}{ Anal. No. } & \multicolumn{6}{|c|}{ Parece Vela Basin } \\
\hline & \multicolumn{4}{|c|}{ West (Site 449) } & \multicolumn{2}{|c|}{ East (Site 450) } \\
\hline & 1 & 2 & 3 & 4 & 5 & 6 \\
\hline Sample & $\begin{array}{c}449-15-2 \\
59 \mathrm{~cm}\end{array}$ & $\begin{array}{c}449-17-1 \\
85 \mathrm{~cm}\end{array}$ & $\begin{array}{l}449-17-1 \\
103 \mathrm{~cm}\end{array}$ & $\begin{array}{l}449-17-2 \\
98 \mathrm{~cm}\end{array}$ & $\begin{array}{c}450-36-3 \\
104 \mathrm{~cm}\end{array}$ & $\begin{array}{c}450-36-3 \\
117 \mathrm{~cm}\end{array}$ \\
\hline $\mathrm{SiO}_{2}$ & 45.87 & 47.05 & 46.10 & 47.00 & 48.54 & 47.61 \\
\hline $\mathrm{TiO}_{2}$ & 0.98 & 0.94 & 0.99 & 1.00 & 1.33 & 1.22 \\
\hline $\mathrm{Al}_{2} \mathrm{O}_{3}$ & 18.09 & 18.23 & 18.00 & 17.20 & 15.78 & 16.08 \\
\hline $\mathrm{Fe}_{2} \mathrm{O}_{3} \mathrm{~b}$ & 10.67 & 10.09 & 10.41 & 10.83 & 9.31 & 9.76 \\
\hline $\mathrm{FeO}$ & 0.0 & 0.0 & 0.0 & 0.0 & 0.0 & 0.0 \\
\hline $\mathrm{MnO}$ & 0.21 & 0.17 & 0.14 & 0.13 & 0.15 & 0.15 \\
\hline $\mathrm{MgO}$ & 3.26 & 4.14 & 3.55 & 4.64 & 5.94 & 6.01 \\
\hline $\mathrm{CaO}$ & 12.32 & 12.82 & 12.95 & 12.04 & 12.40 & 12.30 \\
\hline $\mathrm{Na}_{2} \mathrm{O}$ & 2.14 & 2.08 & 2.07 & 2.23 & 1.99 & 2.16 \\
\hline $\mathrm{K}_{2} \mathrm{O}$ & 0.46 & 0.39 & 0.41 & 0.37 & 0.44 & 0.46 \\
\hline $\mathrm{P}_{2} \mathrm{O}_{5}$ & 0.27 & 0.27 & 0.34 & 0.35 & 0.22 & 0.27 \\
\hline $\mathrm{H}_{2} \mathrm{O}+\mathrm{c}$ & 0.0 & 0.0 & 0.0 & 0.0 & 0.0 & 0.0 \\
\hline $\mathrm{H}_{2} \mathrm{O}^{-\mathrm{c}}$ & 0.0 & 0.0 & 0.0 & 0.0 & 0.0 & 0.0 \\
\hline Total & 94.27 & 96.18 & 94.96 & 95.79 & 96.10 & 96,02 \\
\hline \multicolumn{7}{|l|}{ CIPW Norm } \\
\hline Q & 6.04 & 5.68 & 5.76 & 5.80 & 6.62 & 4.63 \\
\hline Or & 2.88 & 2.40 & 2.55 & 2.28 & 2.71 & 2.83 \\
\hline $\mathrm{Ab}$ & 19.21 & 18.30 & 18.44 & 19.70 & 17.52 & 19.03 \\
\hline An & 40.73 & 40.81 & 40.66 & 37.40 & 34.16 & 34.18 \\
\hline $\mathrm{Ne}$ & 0.0 & 0.0 & 0.0 & 0.0 & 0.0 & 0.0 \\
\hline Wo & 8.14 & 8.67 & 9.02 & 8.13 & 10.08 & 9.90 \\
\hline En & 7.03 & 7.49 & 7.80 & 7.02 & 8.72 & 8.56 \\
\hline Fs & 0.0 & 0.0 & 0.0 & 0.0 & 0.0 & 0.0 \\
\hline En & 1.58 & 3.23 & 1.51 & 5.04 & 6.68 & 7.03 \\
\hline Fs & 0.0 & 0.0 & 0.0 & 0.0 & 0.0 & 0.0 \\
\hline Fo & 0.0 & 0.0 & 0.0 & 0.0 & 0.0 & 0.0 \\
\hline $\mathrm{Fa}$ & 0.0 & 0.0 & 0.0 & 0.0 & 0.0 & 0.0 \\
\hline $\mathrm{Mt}$ & 0.0 & 0.0 & 0.0 & 0.0 & 0.0 & 0.0 \\
\hline II & 0.48 & 0.38 & 0.32 & 0.29 & 0.33 & 0.33 \\
\hline Ap & 0.66 & 0.65 & 0.83 & 0.85 & 0.53 & 0.65 \\
\hline
\end{tabular}

analyst: T. Ishii.

Total $\mathrm{Fe}$ as $\mathrm{Fe}_{2} \mathrm{O}_{3}$.

c Not determined. 
Table 4. The major-element analyses obtained by XRF method of the rocks from Leg 59, Holes 448A and $451 .^{a}$

\begin{tabular}{|c|c|c|c|c|c|c|}
\hline \multirow[b]{2}{*}{ Anal. No. } & \multicolumn{2}{|c|}{ Palau-Kyushu Ridge } & \multicolumn{4}{|c|}{ West Mariana Ridge } \\
\hline & 1 & 2 & 3 & 4 & 5 & 6 \\
\hline Sample & $\begin{array}{c}448 \mathrm{~A}-62-1 \\
70 \mathrm{~cm}\end{array}$ & $\begin{array}{c}448 \mathrm{~A}-62-2 \\
9 \mathrm{~cm}\end{array}$ & $\begin{array}{c}451-38-1 \\
134 \mathrm{~cm}\end{array}$ & $\begin{array}{c}451-38-2 \\
12 \mathrm{~cm}\end{array}$ & $\begin{array}{c}451-58-2 \\
132 \mathrm{~cm}\end{array}$ & $\begin{array}{c}451-89-2 \\
54 \mathrm{~cm}\end{array}$ \\
\hline $\mathrm{SiO}_{2}$ & 49.71 & 48.30 & 49.59 & 51.68 & 55.61 & 64.55 \\
\hline $\mathrm{TiO}_{2}$ & 0.92 & 0.92 & 0.63 & 0.76 & 0.67 & 0.85 \\
\hline $\mathrm{Al}_{2} \mathrm{O}_{3}$ & 18.67 & 18.49 & 19.03 & 17.21 & 18.33 & 14.12 \\
\hline $\mathrm{Fe}_{2} \mathrm{O}_{3} \mathrm{~b}$ & 10.47 & 10.66 & 9.64 & 10.73 & 6.74 & 6.73 \\
\hline $\mathrm{FeO}$ & 0.0 & 0.0 & 0.0 & 0.0 & 0.0 & 0.0 \\
\hline $\mathrm{MnO}$ & 0.15 & 0.12 & 0.16 & 0.17 & 0.13 & 0.12 \\
\hline $\mathrm{MgO}$ & 3.86 & 4.08 & 3.65 & 3.27 & 1.89 & 0.80 \\
\hline $\mathrm{CaO}$ & 10.84 & 10.87 & 10.45 & 8.89 & 8.84 & 5.21 \\
\hline $\mathrm{Na}_{2} \mathrm{O}$ & 1.87 & 1.84 & 1.65 & 2.15 & 2.62 & 2.41 \\
\hline $\mathrm{K}_{2} \mathrm{O}$ & 0.21 & 0.13 & 0.71 & 1.04 & 2.41 & 1.92 \\
\hline $\mathrm{P}_{2} \mathrm{O}_{5}$ & 0.20 & 0.20 & 0.20 & 0.29 & 0.31 & 0.56 \\
\hline $\mathrm{H}_{2} \mathrm{O}+\mathrm{c}$ & 0.0 & 0.0 & 0.0 & 0.0 & 0.0 & 0.0 \\
\hline $\mathrm{H}_{2} \mathrm{O}^{-\mathrm{c}}$ & 0.0 & 0.0 & 0.0 & 0.0 & 0.0 & 0.0 \\
\hline Total & 96.90 & 95.61 & 95.71 & 96.19 & 97.55 & 97.27 \\
\hline \multicolumn{7}{|l|}{ CIPW Norm } \\
\hline Q & 12.27 & 11.12 & 12.29 & 14.36 & 12.89 & 33.35 \\
\hline Or & 1.28 & 0.80 & 4.38 & 6.39 & 14.60 & 11.66 \\
\hline $\mathrm{Ab}$ & 16.33 & 16.28 & 14.59 & 18.91 & 22.72 & 20.96 \\
\hline An & 43.27 & 43.73 & 44.32 & 35.59 & 31.92 & 22.66 \\
\hline $\mathrm{Ne}$ & 0.0 & 0.0 & 0.0 & 0.0 & 0.0 & 0.0 \\
\hline Wo & 3.42 & 3.53 & 2.86 & 2.60 & 3.80 & 0.0 \\
\hline En & 2.95 & 3.05 & 2.47 & 2.25 & 3.28 & 0.0 \\
\hline Fs & 0.0 & 0.0 & 0.0 & 0.0 & 0.0 & 0.0 \\
\hline En & 6.97 & 7.58 & 7.03 & 6.22 & 1.54 & 2.05 \\
\hline Fs & 0.0 & 0.0 & 0.0 & 0.0 & 0.0 & 0.0 \\
\hline Fo & 0.0 & 0.0 & 0.0 & 0.0 & 0.0 & 0.0 \\
\hline $\mathrm{Fa}$ & 0.0 & 0.0 & 0.0 & 0.0 & 0.0 & 0.0 \\
\hline Mt & 0.0 & 0.0 & 0.0 & 0.0 & 0.0 & 0.0 \\
\hline II & 0.33 & 0.27 & 0.36 & 0.38 & 0.29 & 0.26 \\
\hline Ap & 0.48 & 0.48 & 0.48 & 0.70 & 0.74 & 1.33 \\
\hline
\end{tabular}

a Analyst: T. Ishii.

b Total $\mathrm{Fe}$ as $\mathrm{Fe}_{2} \mathrm{O}_{3}$.

c Not determined. 
Table 5. The major-element analyses obtained by EPMA of the glass from Leg 59, Hole 447A. ${ }^{a}$

\begin{tabular}{|c|c|c|c|c|c|c|c|}
\hline \multirow[b]{2}{*}{ Anal. No. } & \multicolumn{7}{|c|}{ West Philippine Sea Basin } \\
\hline & $1^{\mathrm{d}}$ & 2 & 3 & 4 & 5 & 6 & $7^{e}$ \\
\hline Sample & $\begin{array}{c}447 \mathrm{~A}-17-1 \\
79 \mathrm{~cm}\end{array}$ & $\begin{array}{c}447 \mathrm{~A}-22-1 \\
112 \mathrm{~cm}\end{array}$ & $\begin{array}{c}447 \mathrm{~A}-22-2 \\
34 \mathrm{~cm}\end{array}$ & $\begin{array}{c}447 \mathrm{~A}-32-1 \\
69 \mathrm{~cm}\end{array}$ & $\begin{array}{c}447 \mathrm{~A}-35-3 \\
70 \mathrm{~cm}\end{array}$ & $\begin{array}{c}447 \mathrm{~A}-36-2 \\
35 \mathrm{~cm}\end{array}$ & $\begin{array}{c}447 \mathrm{~A}-36-3, \\
90 \mathrm{~cm}\end{array}$ \\
\hline $\mathrm{SiO}_{2}$ & 46.85 & 49.89 & 49.01 & 50.44 & 50.37 & 50.15 & 48.44 \\
\hline $\mathrm{TiO}_{2}$ & 1.05 & 1.04 & 1.05 & 0.84 & 0.92 & 0.90 & 0.88 \\
\hline $\mathrm{Al}_{2} \mathrm{O}_{3}$ & 15.92 & 14.86 & 14.54 & 15.09 & 15.41 & 15.41 & 14.93 \\
\hline $\mathrm{Fe}_{2} \mathrm{O}_{3} \mathrm{~b}$ & 1.23 & 1.29 & 1.30 & 1.15 & 1.22 & 1.21 & 1.27 \\
\hline $\mathrm{FeO}$ & 8.22 & 8.61 & 8.66 & 7.64 & 8.13 & 8.05 & 8.44 \\
\hline $\mathrm{MnO}$ & 0.15 & 0.16 & 0.17 & 0.13 & 0.13 & 0.15 & 0.23 \\
\hline $\mathrm{MgO}$ & 8.39 & 8.23 & 8.26 & 8.90 & 8.67 & 8.70 & 8.06 \\
\hline $\mathrm{CaO}$ & 11.97 & 12.22 & 12.22 & 13.12 & 12.76 & 12.61 & 11.45 \\
\hline $\mathrm{Na}_{2} \mathrm{O}$ & 2.68 & 2.15 & 2.17 & 1.84 & 2.07 & 2.09 & 2.25 \\
\hline $\mathrm{K}_{2} \mathrm{O}$ & 0.09 & 0.06 & 0.04 & 0.04 & 0.04 & 0.04 & 0.64 \\
\hline $\mathrm{P}_{2} \mathrm{O}_{5} \mathrm{c}$ & 0.0 & 0.0 & 0.0 & 0.0 & 0.0 & 0.0 & 0.0 \\
\hline $\mathrm{H}_{2} \mathrm{O}+\mathrm{c}$ & 0.0 & 0.0 & 0.0 & 0.0 & 0.0 & 0.0 & 0.0 \\
\hline $\mathrm{H}_{2} \mathrm{O}-\mathrm{c}$ & 0.0 & 0.0 & 0.0 & 0.0 & 0.0 & 0.0 & 0.0 \\
\hline Total & 96.61 & 98.57 & 97.48 & 99.27 & 99.76 & 99.37 & 97.89 \\
\hline \multicolumn{8}{|l|}{ CIPW Norm } \\
\hline Q & 0.0 & 0.0 & 0.0 & 0.0 & 0.0 & 0.0 & 0.0 \\
\hline Or & 0.55 & 0.36 & 0.24 & 0.24 & 0.24 & 0.24 & 3.86 \\
\hline $\mathrm{Ab}$ & 21.61 & 18.46 & 18.84 & 15.68 & 17.56 & 17.80 & 19.45 \\
\hline An & 32.24 & 31.16 & 30.59 & 33.04 & 32.72 & 32.75 & 29.37 \\
\hline $\mathrm{Ne}$ & 1.01 & 0.0 & 0.0 & 0.0 & 0.0 & 0.0 & 0.0 \\
\hline Wo & 12.20 & 12.67 & 13.20 & 13.58 & 12.83 & 12.61 & 11.97 \\
\hline En & 7.21 & 7.32 & 7.62 & 8.31 & 7.66 & 7.56 & 7.05 \\
\hline Fs & 4.38 & 4.77 & 4.98 & 4.51 & 4.51 & 4.39 & 4.32 \\
\hline En & 0.0 & 11.40 & 9.54 & 13.32 & 11.09 & 11.00 & 6.04 \\
\hline Fs & 0.0 & 7.42 & 6.23 & 7.23 & 6.53 & 6.39 & 3.70 \\
\hline Fo & 10.10 & 1.46 & 2.77 & 0.49 & 2.03 & 2.27 & 5.19 \\
\hline $\mathrm{Fa}$ & 6.77 & 1.04 & 1.99 & 0.29 & 1.32 & 1.45 & 3.51 \\
\hline Mt & 1.85 & 1.90 & 1.93 & 1.68 & 1.77 & 1.77 & 1.88 \\
\hline Il & 2.06 & 2.00 & 2.05 & 1.61 & 1.75 & 1.72 & 1.71 \\
\hline Ap & 0.0 & 0.0 & 0.0 & 0.0 & 0.0 & 0.0 & 0.0 \\
\hline
\end{tabular}

a Analyst: T. Ishii.

b $\mathrm{Fe}_{2} \mathrm{O}_{3} / \mathrm{FeO}=0.15$.

c Not determined.

d Degree of reliability is relatively low.

${ }^{e}$ Glass in the plagioclase aggregate. 
Table 6. The major-element analyses obtained by EPMA of the glass from Leg 59, Holes 449 and 450 . $^{\mathrm{a}}$

\begin{tabular}{|c|c|c|c|c|c|}
\hline \multirow[b]{2}{*}{ Anal. No. } & \multicolumn{5}{|c|}{ Parece Vela Basin } \\
\hline & 1 & 2 & 3 & 4 & 5 \\
\hline Sample & $\begin{array}{c}449-15-2 \\
1 \mathrm{~cm}\end{array}$ & $\begin{array}{c}449-15-2 \\
59 \mathrm{~cm}\end{array}$ & $\begin{array}{c}450-36-3 \\
134 \mathrm{~cm}\end{array}$ & $\begin{array}{c}450-36-3 \\
134 \mathrm{~cm}\end{array}$ & $\begin{array}{c}450-36-3 \\
134 \mathrm{~cm}\end{array}$ \\
\hline $\mathrm{SiO}_{2}$ & 48.59 & 48.77 & 49.54 & 49.32 & 49.05 \\
\hline $\mathrm{TiO}_{2}$ & 1.01 & 0.99 & 1.52 & 1.55 & 1.52 \\
\hline $\mathrm{Al}_{2} \mathrm{O}_{3}$ & 15.80 & 16.25 & 14.87 & 14.99 & 14.74 \\
\hline $\mathrm{Fe}_{2} \mathrm{O}_{3} \mathrm{~b}$ & 1.26 & 1.25 & 1.30 & 1.30 & 1.28 \\
\hline $\mathrm{FeO}$ & 8.40 & 8.32 & 8.69 & 8.66 & 8.56 \\
\hline $\mathrm{MnO}$ & 0.15 & 0.17 & 0.16 & 0.16 & 0.14 \\
\hline $\mathrm{MgO}$ & 7.72 & 7.65 & 7.75 & 7.71 & 7.51 \\
\hline $\mathrm{CaO}$ & 11.58 & 11.62 & 11.79 & 11.73 & 11.65 \\
\hline $\mathrm{Na}_{2} \mathrm{O}$ & 2.51 & 2.56 & 2.76 & 3.01 & 1.28 \\
\hline $\mathrm{K}_{2} \mathrm{O}$ & 0.19 & 0.19 & 0.10 & 0.08 & 0.16 \\
\hline $\mathrm{P}_{2} \mathrm{O}_{5} \mathrm{c}$ & 0.0 & 0.0 & 0.0 & 0.0 & 0.0 \\
\hline $\mathrm{H}_{2} \mathrm{O}+\mathrm{c}$ & 0.0 & 0.0 & 0.0 & 0.0 & 0.0 \\
\hline $\mathrm{H}_{2} \mathrm{O}-\mathrm{c}$ & 0.0 & 0.0 & 0.0 & 0.0 & 0.0 \\
\hline Total & 97.25 & 97.77 & 98.51 & 98.58 & 95.90 \\
\hline \multicolumn{6}{|l|}{ CIPW Norm } \\
\hline Q & 0.0 & 0.0 & 0.0 & 0.0 & 4.50 \\
\hline Or & 1.15 & 1.15 & 0.60 & 0.48 & 0.99 \\
\hline $\mathrm{Ab}$ & 21.84 & 22.15 & 23.71 & 25.83 & 11.29 \\
\hline An & 32.17 & 33.02 & 28.31 & 27.54 & 35.45 \\
\hline $\mathrm{Ne}$ & 0.0 & 0.0 & 0.0 & 0.0 & 0.0 \\
\hline Wo & 11.23 & 10.83 & 12.97 & 13.15 & 10.36 \\
\hline En & 6.42 & 6.17 & 7.46 & 7.58 & 5.95 \\
\hline Fs & 4.33 & 4.19 & 4.92 & 4.97 & 3.95 \\
\hline En & 5.85 & 5.30 & 5.59 & 2.52 & 13.56 \\
\hline Fs & 3.94 & 3.59 & 3.69 & 1.65 & 9.01 \\
\hline Fo & 5.26 & 5.62 & 4.58 & 6.57 & 0.0 \\
\hline $\mathrm{Fa}$ & 3.91 & 4.20 & 3.33 & 4.75 & 0.0 \\
\hline Mt & 1.88 & 1.85 & 1.91 & 1.91 & 1.94 \\
\hline II & 1.97 & 1.92 & 2.93 & 2.99 & 3.01 \\
\hline Ap & 0.0 & 0.0 & 0.0 & 0.0 & 0.0 \\
\hline
\end{tabular}

a Analyst: T. Ishii.

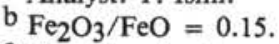

c Not determined. 
Table 7. The major-element analyses obtained by EPMA of the glass from Leg 59, Holes 448 and 448A. ${ }^{a}$

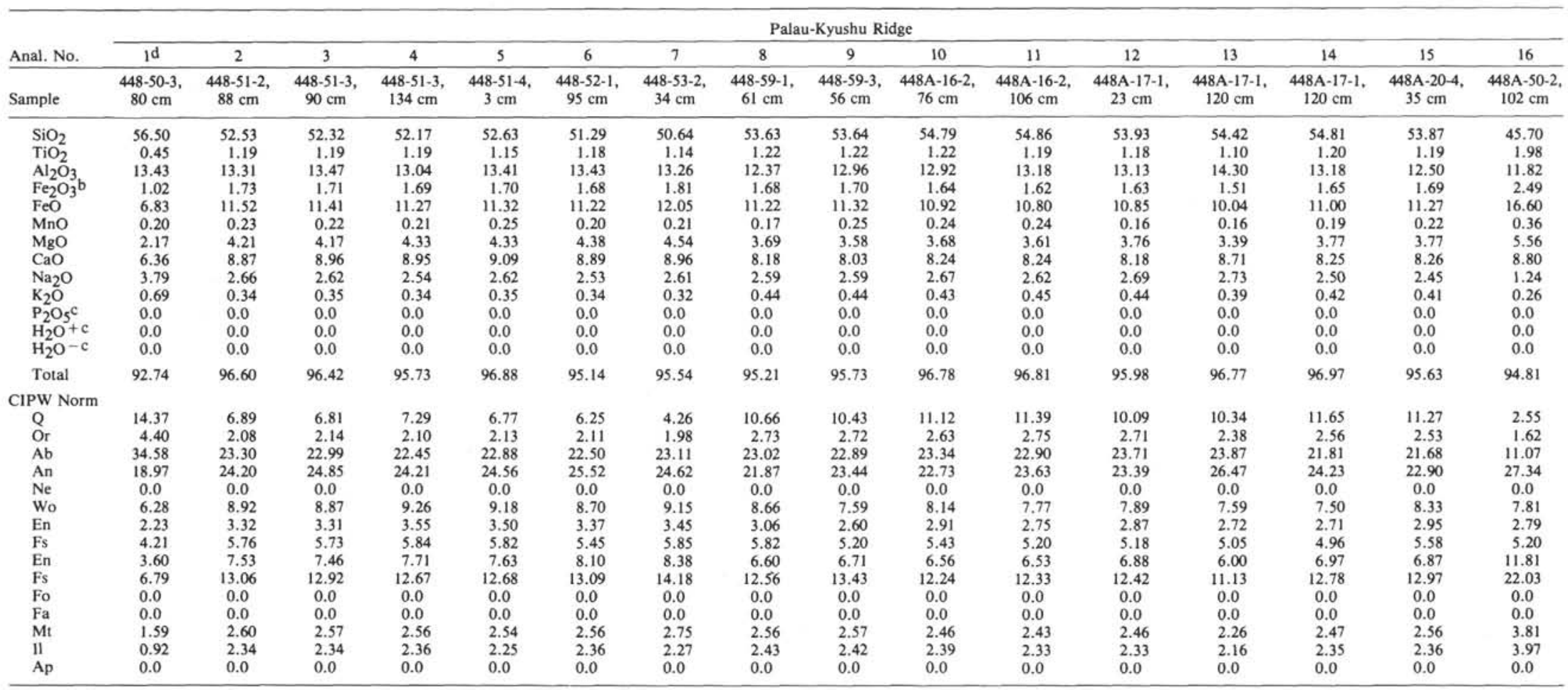

a Analyst: T. Ishii.

$\mathrm{Fe}_{2} \mathrm{O}_{3} / \mathrm{FeO}=0.15 .7$
Not determined.

d Roughly estimated analysis of hornblende gabbro. 
Table 8. The major-element analyses by EPMA of the groundmass (see text) in the rock from Leg 59 , Hole 451 . $^{\mathrm{a}}$

\begin{tabular}{|c|c|c|c|c|c|}
\hline \multirow[b]{2}{*}{ Anal. No. } & \multicolumn{5}{|c|}{ West Mariana Ridge } \\
\hline & 1 & 2 & 3 & 4 & 5 \\
\hline Sample & $\begin{array}{c}451-38-2 \\
12 \mathrm{~cm}\end{array}$ & $\begin{array}{c}451-58-2 \\
132 \mathrm{~cm}\end{array}$ & $\begin{array}{c}451-59-1, \\
60 \mathrm{~cm}\end{array}$ & $\begin{array}{c}451-69-2 \\
85 \mathrm{~cm}\end{array}$ & $\begin{array}{c}451-89-2, \\
54 \mathrm{~cm}\end{array}$ \\
\hline $\mathrm{SiO}_{2}$ & 58.95 & 66.31 & 64.05 & 61.87 & 63.87 \\
\hline $\mathrm{TiO}_{2}$ & 0.86 & 0.53 & 0.48 & 0.48 & 0.91 \\
\hline $\mathrm{Al}_{2} \mathrm{O}_{3}$ & 18.10 & 16.05 & 17.35 & 14.50 & 15.95 \\
\hline $\mathrm{Fe}_{2} \mathrm{O}_{3} \mathrm{~b}$ & 0.96 & 0.41 & 0.35 & 0.61 & 0.76 \\
\hline $\mathrm{FeO}$ & 6.39 & 2.75 & 2.36 & 4.06 & 5.10 \\
\hline $\mathrm{MnO}$ & 0.16 & 0.04 & 0.03 & 0.18 & 0.11 \\
\hline $\mathrm{MgO}$ & 2.20 & 0.69 & 0.45 & 1.12 & 0.73 \\
\hline $\mathrm{CaO}$ & 6.96 & 4.04 & 4.71 & 4.04 & 5.35 \\
\hline $\mathrm{Na}_{2} \mathrm{O}$ & 4.04 & 4.11 & 4.15 & 4.63 & 3.62 \\
\hline $\mathrm{K}_{2} \mathrm{O}$ & 1.63 & 3.38 & 3.20 & 1.71 & 2.04 \\
\hline $\mathrm{P}_{2} \mathrm{O}_{5} \mathrm{c}$ & 0.0 & 0.0 & 0.0 & 0.0 & 0.0 \\
\hline $\mathrm{H}_{2} \mathrm{O}+\mathrm{c}$ & 0.0 & 0.0 & 0.0 & 0.0 & 0.0 \\
\hline $\mathrm{H}_{2} \mathrm{O}^{-\mathrm{c}}$ & 0.0 & 0.0 & 0.0 & 0.0 & 0.0 \\
\hline Total & 100.25 & 98.31 & 97.17 & 93.20 & 98.44 \\
\hline \multicolumn{6}{|l|}{ CIPW Norm } \\
\hline Q & 8.28 & 19.34 & 16.76 & 17.68 & 20.53 \\
\hline Or & 9.61 & 20.32 & 19.46 & 10.84 & 12.25 \\
\hline $\mathrm{Ab}$ & 34.10 & 35.37 & 36.14 & 42.03 & 31.11 \\
\hline An & 26.37 & 15.33 & 19.82 & 14.73 & 21.58 \\
\hline $\mathrm{Ne}$ & 0.0 & 0.0 & 0.0 & 0.0 & 0.0 \\
\hline Wo & 3.37 & 1.99 & 1.76 & 2.83 & 2.25 \\
\hline En & 1.23 & 0.63 & 0.47 & 0.88 & 0.47 \\
\hline Fs & 2.21 & 1.43 & 1.38 & 2.05 & 1.93 \\
\hline En & 4.23 & 1.12 & 0.68 & 2.11 & 1.38 \\
\hline Fs & 7.59 & 2.55 & 2.01 & 4.91 & 5.63 \\
\hline Fo & 0.0 & 0.0 & 0.0 & 0.0 & 0.0 \\
\hline $\mathrm{Fa}$ & 0.0 & 0.0 & 0.0 & 0.0 & 0.0 \\
\hline Mt & 1.39 & 0.60 & 0.52 & 0.95 & 1.12 \\
\hline Il & 1.63 & 1.02 & 0.94 & 0.98 & 1.76 \\
\hline Ap & 0.0 & 0.0 & 0.0 & 0.0 & 0.0 \\
\hline
\end{tabular}

a Analyst: T. Ishii.

b $\mathrm{Fe}_{2} \mathrm{O}_{3} / \mathrm{FeO}=0.15$.

c Not determined. 

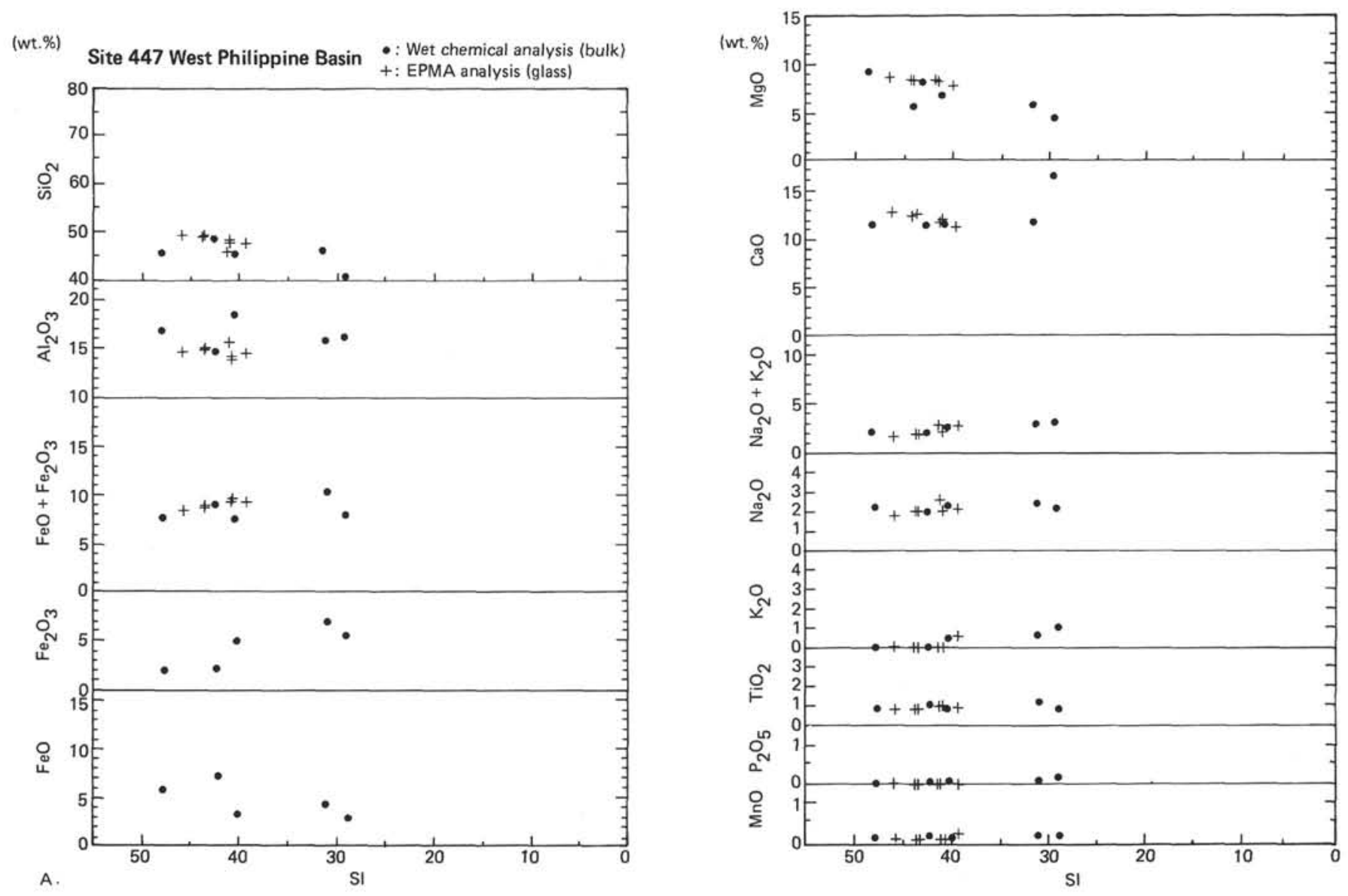

Figure 1. Oxide (wt. \%)-solidification index (SI) diagram of chemical analyses of rocks and glasses from Site 447 in the West Philippine Sea (A), Site 448 on the Palau-Kyushu Ridge (B), Site 449 and 450 in the Parece Vera Basin (C), and Site 451 on the West Mariana Ridge (D). 

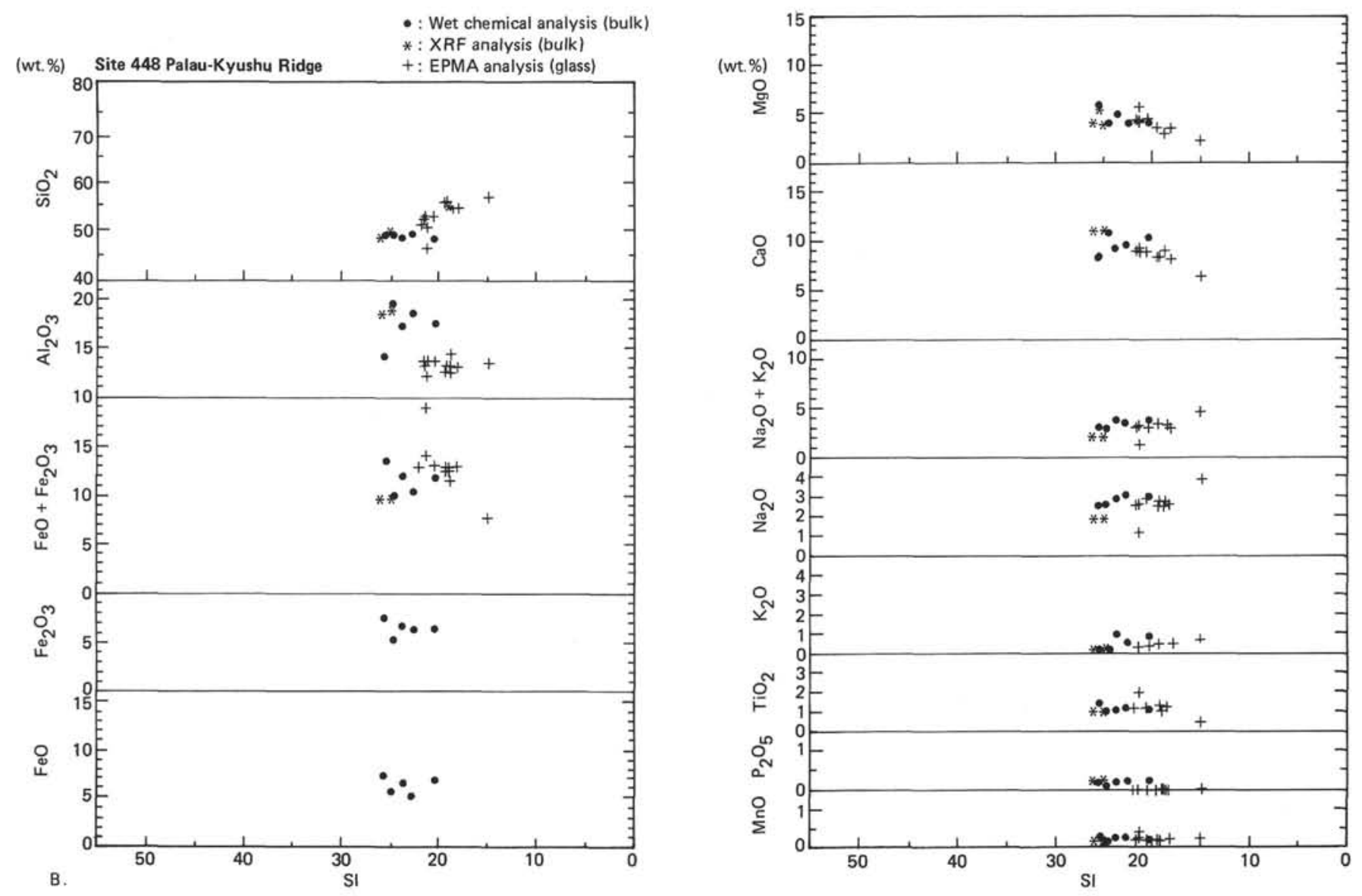

Figure 1. (Continued). 
- : Wet chemical analysis (bulk

* : XRF analysis (bulk)

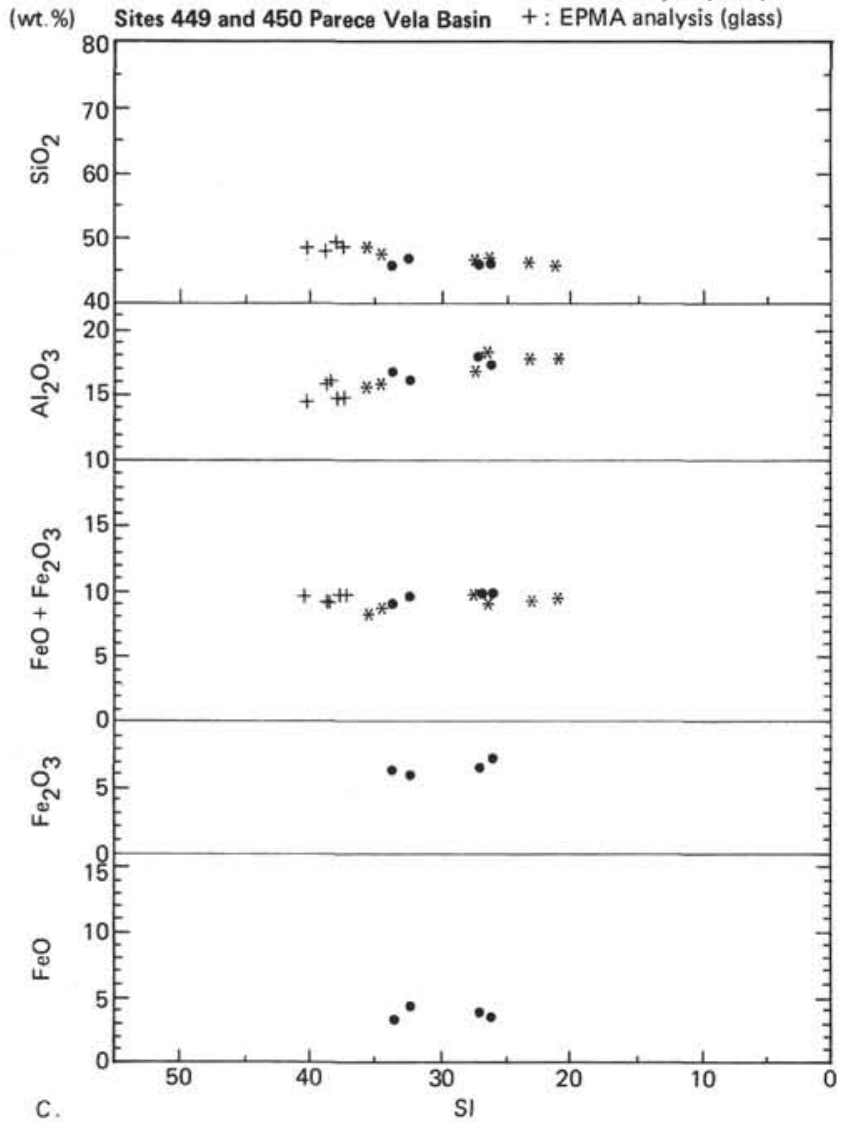

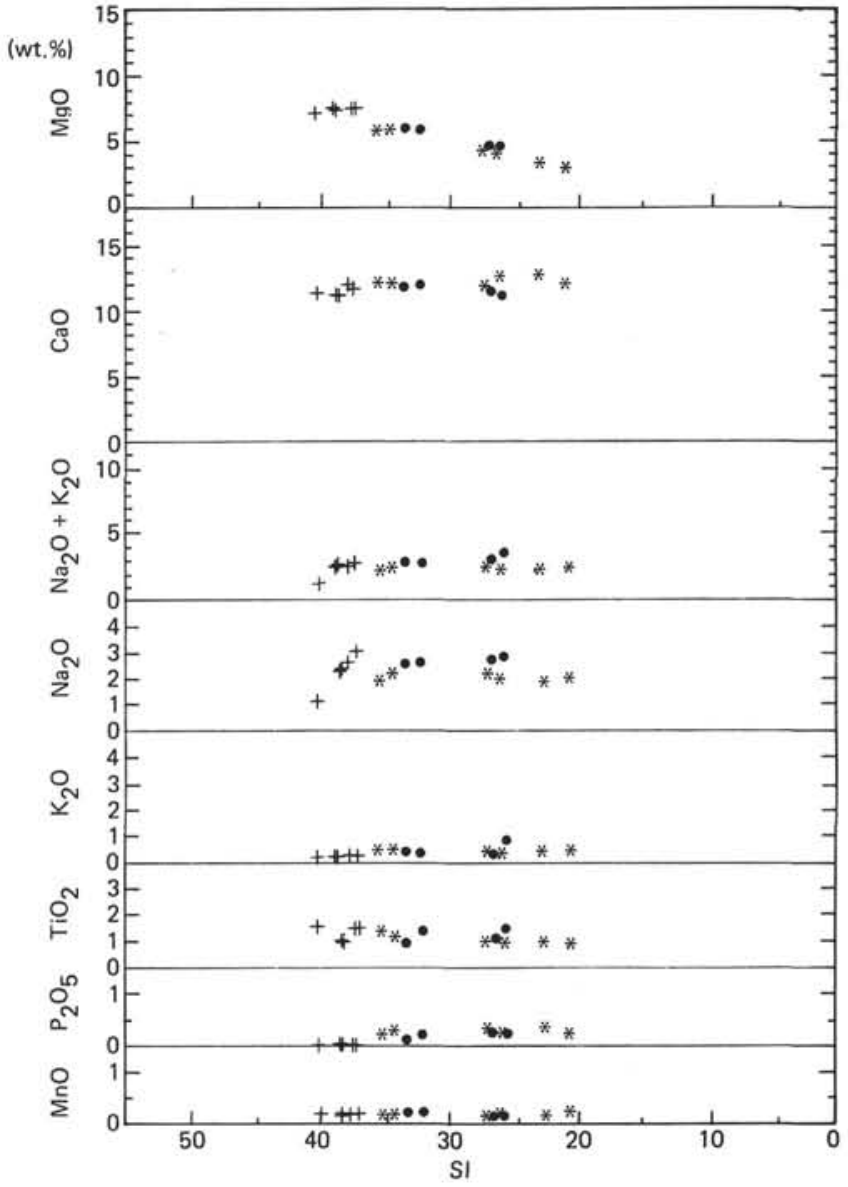

Figure 1. (Continued). 

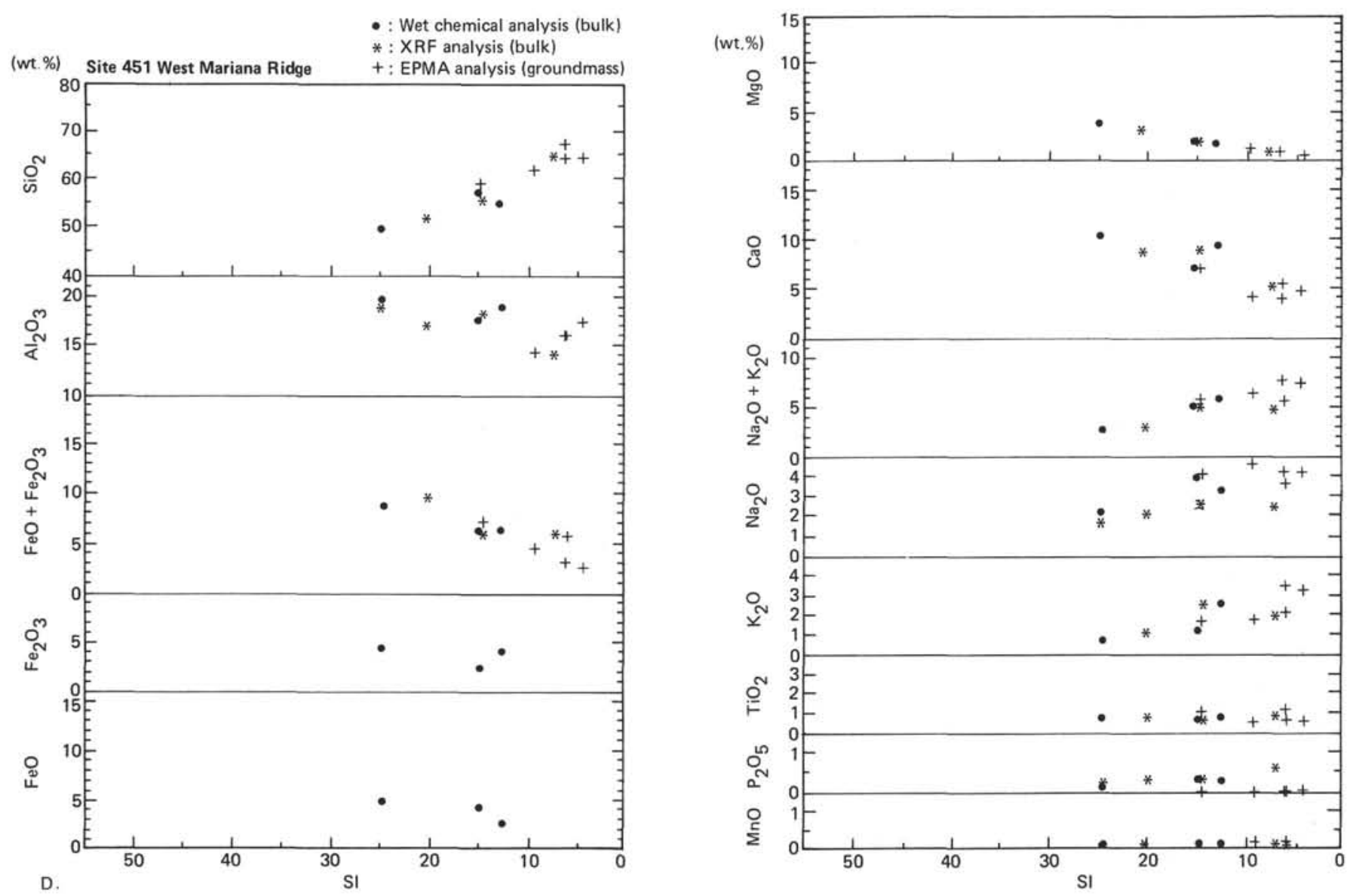

Figure 1. (Continued). 
Table 9. The pyroxene and hornblende analyses from Leg 59. ${ }^{\mathrm{a}}$

\begin{tabular}{|c|c|c|c|c|c|}
\hline \multirow[b]{4}{*}{ Anal. No. } & \multirow{2}{*}{\multicolumn{3}{|c|}{$\begin{array}{c}\begin{array}{c}\text { Plagioclase-phyric } \\
\text { basalt }(\mathrm{G} 740),\end{array} \\
\text { Sample } 447 \mathrm{~A}-36-5,7 \mathrm{~cm}\end{array}$}} & \multicolumn{2}{|c|}{$\begin{array}{l}\text { Hornblende gabbro } \\
\text { (1803), Sample } \\
448-50-3,80 \mathrm{~cm}\end{array}$} \\
\hline & & & & \multirow{3}{*}{$\frac{\overline{\text { Augite }}}{\frac{\text { Phc. }}{1811}}$} & \multirow{3}{*}{$\frac{\frac{\text { Hornb. }}{\text { Phc. }}}{1810}$} \\
\hline & \multicolumn{2}{|c|}{ Groundmass } & \multirow{2}{*}{$\frac{\text { Xenoc. }}{G 904}$} & & \\
\hline & G804 & G805 & & & \\
\hline $\mathrm{SiO}_{2}$ & 47.82 & 48.49 & 49.13 & 50.40 & 49.44 \\
\hline $\mathrm{Al}_{2} \mathrm{O}_{3}$ & 6.39 & 5.54 & 11.88 & 0.42 & 3.09 \\
\hline $\mathrm{TiO}_{2}$ & 1.67 & 1.52 & 0.46 & 0.02 & 0.28 \\
\hline $\mathrm{Cr}_{2} \mathrm{O}_{3}$ & 0.28 & 0.81 & 0.08 & 0.00 & 0.00 \\
\hline $\mathrm{FeO} \mathrm{O}^{\circ}$ & 5.98 & 6.54 & 8.64 & 11.54 & 21.83 \\
\hline $\mathrm{MnO}$ & 0.08 & 0.11 & 0.22 & 0.77 & 0.77 \\
\hline $\mathrm{MgO}$ & 12.73 & 13.15 & 13.52 & 11.02 & 9.94 \\
\hline $\mathrm{CaO}$ & 22.88 & 22.92 & 14.14 & 23.83 & 10.71 \\
\hline $\mathrm{Na}_{2} \mathrm{O}$ & 0.59 & 0.50 & 1.61 & 0.24 & 0.62 \\
\hline $\mathrm{K}_{2} \mathrm{O}$ & - & - & - & - & 0.13 \\
\hline Total & 98.42 & 99.58 & 99.68 & 98.24 & 96.81 \\
\hline \multicolumn{6}{|l|}{$0=6.000$} \\
\hline $\mathrm{Si}$ & 1.806 & 1.816 & 1.794 & 1.963 & 1.970 \\
\hline $\mathrm{Al}$ & 0.194 & 0.184 & 0.206 & 0.019 & 0.030 \\
\hline $\mathrm{Al}$ & 0.090 & 0.060 & 0.305 & 0.000 & 0.115 \\
\hline $\mathrm{Ti}$ & 0.047 & 0.043 & 0.013 & 0.001 & 0.008 \\
\hline $\mathrm{Cr}_{\mathrm{r}}$ & 0.008 & 0.024 & 0.002 & 0.000 & 0.000 \\
\hline $\mathrm{Fe}$ & 0.189 & 0.205 & 0.264 & 0.376 & 0.728 \\
\hline Mn & 0.003 & 0.003 & 0.007 & 0.025 & 0.026 \\
\hline $\mathrm{Mg}$ & 0.716 & 0.734 & 0.736 & 0.640 & 0.590 \\
\hline $\mathrm{Ca}$ & 0.926 & 0.920 & 0.553 & 0.994 & 0.457 \\
\hline $\mathrm{Na}$ & 0.043 & 0.036 & 0.114 & 0.018 & 0.048 \\
\hline $\mathrm{K}$ & - & - & - & - & 0.024 \\
\hline & 2.000 & 2.000 & 2.000 & 1.982 & - \\
\hline WXY & 2.022 & 2.025 & 1.994 & 2.054 & - \\
\hline \multicolumn{6}{|l|}{ Atomic $\%$} \\
\hline & 50.6 & 49.5 & 35.6 & 49.5 & 25.8 \\
\hline $\mathrm{M}_{8}$ & & & & 31.8 & 33.3 \\
\hline $\mathrm{Fe}$ & 10.3 & 11.0 & 17.0 & 18.7 & 41.0 \\
\hline
\end{tabular}

a Abbreviations: Hornb. = hornblende, Xenoc. = xenocryst, $\mathrm{b}_{\mathrm{FeO}}$ and $=$ total $\mathrm{Fe}$ as $\mathrm{FeO}$.

Table 10. The plagioclase analyses from Leg $59 .^{\mathrm{a}}$

\begin{tabular}{|c|c|c|c|c|}
\hline \multirow[b]{4}{*}{ Anal. No. } & \multirow{2}{*}{\multicolumn{2}{|c|}{$\begin{array}{c}\text { Plagioclase-phyric } \\
\text { basalt (G740); } \\
\text { Sample } 447 \mathrm{~A}-36-5, \\
7 \mathrm{~cm} \\
\text { Plagioclase } \\
\end{array}$}} & \multirow{4}{*}{$\begin{array}{c}\text { Pl. aggre- } \\
\text { gate (H7389), } \\
\text { Sample } 447 \mathrm{~A}-36-3, \\
90 \mathrm{~cm} \\
\text { Pl. } \\
\text { Phc. } \\
\text { H808 }\end{array}$} & \multirow{3}{*}{$\begin{array}{c}\text { Hoinb. } \\
\text { gabbro (1803) } \\
\text { Sample } 448-50-3, \\
80 \mathrm{~cm} \\
\text { Pl. } \\
\text { Phc. } \\
\end{array}$} \\
\hline & & & & \\
\hline & Xenoc. & Phc. & & \\
\hline & G806 & G807 & & 1813 \\
\hline $\mathrm{SiO}_{2}$ & 43.11 & 45.88 & 46.71 & 51.62 \\
\hline $\mathrm{Al}_{2} \mathrm{O}_{3}$ & 35.25 & 33.49 & 33.53 & 29.94 \\
\hline $\mathrm{TiO}_{2}$ & 0.00 & 0.00 & 0.00 & 0.02 \\
\hline $\mathrm{Cr}_{2} \mathrm{O}_{3}$ & 0.03 & 0.01 & 0.00 & 0.01 \\
\hline $\mathrm{FeO} * 5$ & 0.31 & 0.35 & 0.30 & 0.66 \\
\hline $\mathrm{MnO}$ & 0.00 & 0.02 & 0.02 & 0.00 \\
\hline $\mathrm{MgO}$ & 0.21 & 0.26 & 0.28 & 0.12 \\
\hline $\mathrm{CaO}$ & 19.43 & 17.83 & 17.09 & 13.46 \\
\hline $\mathrm{Na}_{2} \mathrm{O}$ & 0.81 & 1.71 & 2.09 & 4.24 \\
\hline $\mathrm{K}_{2} \mathrm{O}$ & 0.00 & 0.01 & 0.01 & 0.01 \\
\hline Total & 99.15 & 99.56 & 100.03 & 100.17 \\
\hline \multicolumn{5}{|l|}{$0=6.000$} \\
\hline $\mathrm{Si}$ & 1.515 & 1.596 & 1.613 & 1.765 \\
\hline $\mathrm{Al}$ & 1.460 & 1.374 & 1.365 & 1.207 \\
\hline $\mathrm{Ti}$ & 0.000 & 0.000 & 0.000 & 0.001 \\
\hline $\mathrm{Cr}$ & 0.001 & 0.000 & 0.000 & 0.000 \\
\hline $\mathrm{Fe}$ & 0.009 & 0.010 & 0.009 & 0.019 \\
\hline $\mathrm{Mn}$ & 0.000 & 0.001 & 0.001 & 0.000 \\
\hline $\mathrm{Mg}$ & 0.011 & 0.013 & 0.014 & 0.006 \\
\hline $\mathrm{Ca}$ & 0.732 & 0.665 & 0.632 & 0.493 \\
\hline $\mathrm{Na}$ & 0.055 & 0.115 & 0.140 & 0.281 \\
\hline K & 0.000 & 0.001 & 0.002 & 0.017 \\
\hline \multicolumn{5}{|l|}{ Atomic\% } \\
\hline $\mathrm{Na}$ & 7.01 & 14.78 & 18.11 & 36.10 \\
\hline $\mathrm{Ca}$ & 92.99 & 85.16 & 81.83 & 63.34 \\
\hline $\mathbf{K}$ & 0.00 & 0.06 & 0.06 & 0.56 \\
\hline
\end{tabular}
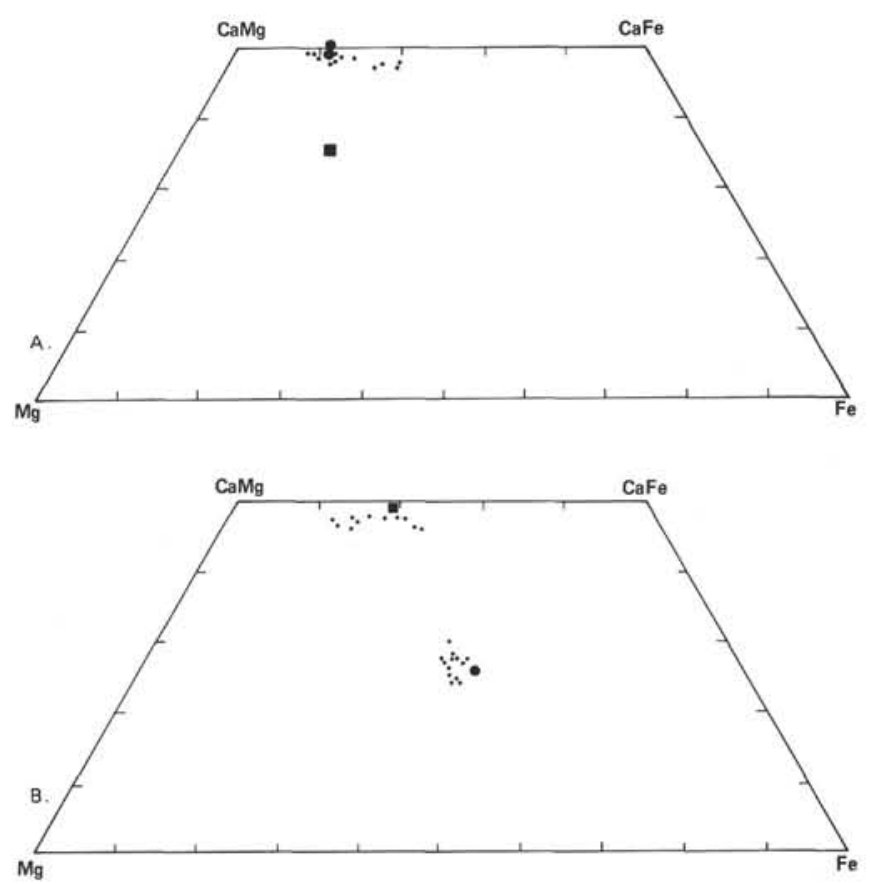

Figure 2. A. Ca-Mg-Fe plot of analyzed pyroxene in Rock G740 (plagioclase-phyric basalt, Sample 447A-36-5, $7 \mathrm{~cm}$ ). B. Ca-Mg-Fe pot of analyzed pyroxene and hornblende in Rock I803 (hornblende gabbro, Sample 448-50-3, $80 \mathrm{~cm}$ ).

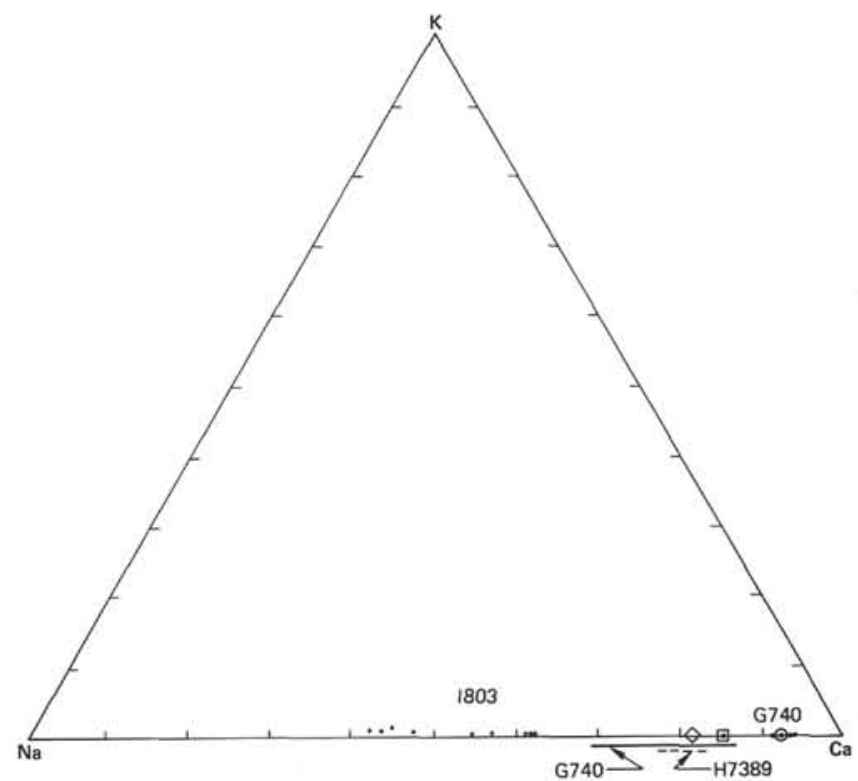

Figure 3. K-Na-Ca plot of analyzed plagioclase in Rocks G740, I803, and H7389 (plagioclase aggregate, Sample 447A-36-3, $90 \mathrm{~cm}$ ). (Lines show compositional ranges of plagioclase.) 